Historic, Archive Document

Do not assume content reflects current scientific knowledge, policies, or practices. 



\section{A Cover Mistake}

The printer made a mistake by transposing the names of $J$. L. Mock, a pink rose shown at the bottom of the front cover page and Souv. De Claudius Pernet a yellow rose in the center.

Please understand that J. L. Mock is pink and Souv. De Claudius is yellow. 



\section{2,67}

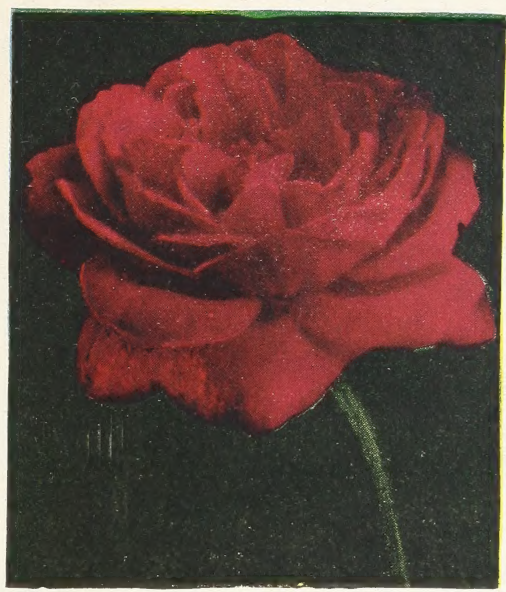

Gen. McArthur

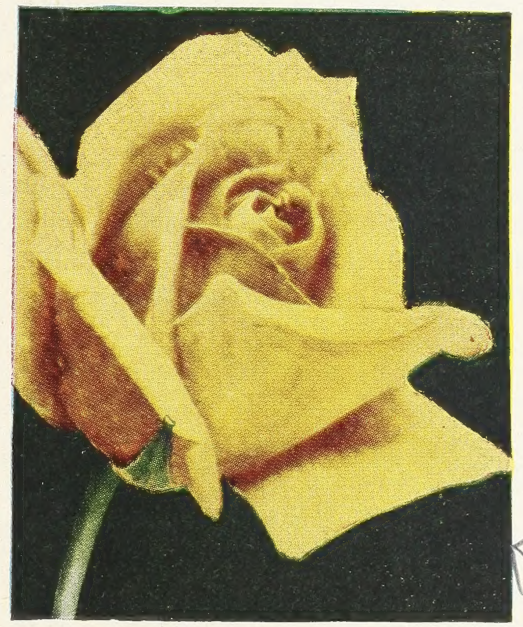

J. L. Mock

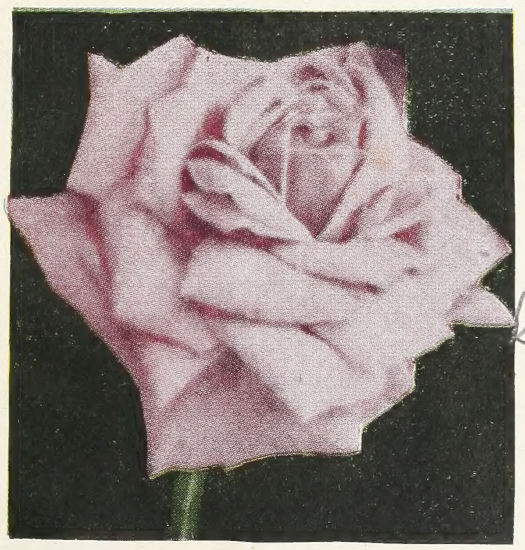

Souv. De Claudius Pernet

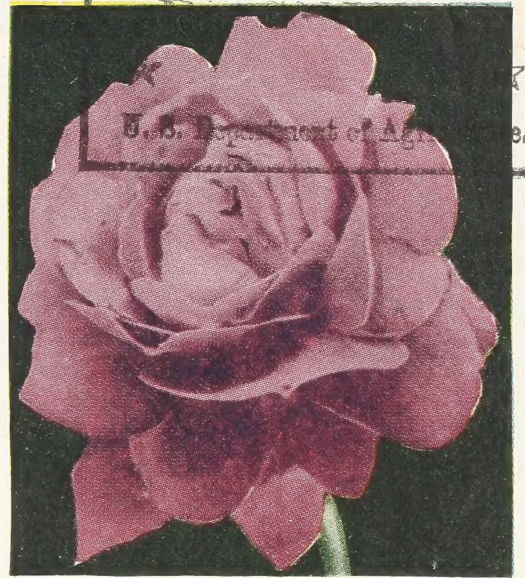

Radiance

THE FREMONT NURSERY 70 YEARS IN BUSINESS HARRY S. DAY, PROPRIETOR

GROWERS OF A COMPLETE LINE OF

Fruit and Ornamental Trees, Shrubs, Roses, Vines and Perennial Plants.

EVERGREENS A SPECIALITY

Fremont, Ohio BRANCHES AT DANSVILLE, N. Y. AND CLYDE, 0. 


\section{INTRODUCTION}

\section{T H E FREMONT}

NURSERY was established in its present location in 1858 and has been in business c o n tin u o usly ever since.

The quality and reliability of our stock together with our reputation for $\mathrm{s} q \mathrm{u}$ a $\mathrm{r}$ e

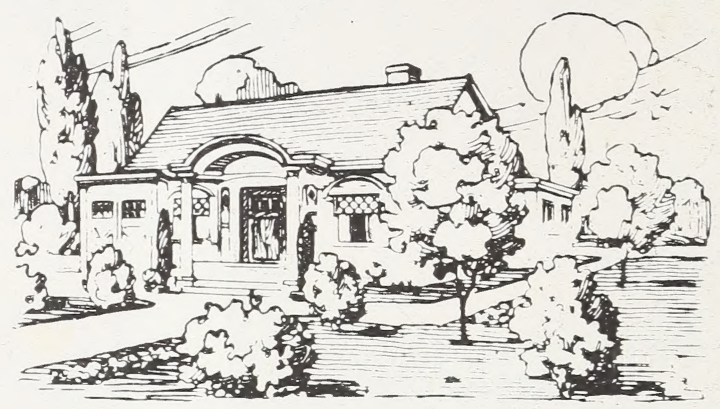
dealing has been the secret of our steady growth.

Our main nursery ground, consisting of about 55 acres, together with our large frost-proof nursery cellar and sales ground, is on South Buckland Ave. near Spiegel Grove State Park, the old homestead of the late President Hayes. Drives lead in from either Buckland Ave. or from South street.

We also have a branch at Dansville, N. Y., where we grow many thousands of fruit trees of certain kinds each year. And we have recently established a branch at the greenhouses of A. Doebel and Son, on the McPherson Highway (Federal Route No. 20) in Clyde, O., where we will maintain a display, show and sales ground and where we will grow a number of acres of ornamental trees, shrubs and evergreens.

Visitors are always welcome to our nursery or display grounds.

We expect to have a display of over 100 varieties of roses blooming at the main nursery grounds and also at the Clyde branch during the coming season.

Insurance and Guarantee-We guarantee our products to be of first quality, healthy and true to name. Any that do not so prove will be cheerfully replaced or purchase price refunded. We are not liable further than the original purchase price.

No one can do more than this at our prices. But for those who wish a further guarantee of growth we will make this special insurance proposition.

If payment in full is made on delivery of stock, plus $25 \%$ of same, we will guarantee the growth of same till the first day of the next following month of September, unless the stock is injured by fire, cattle, hogs or other stock, accidental or wilful or malicious destruction or by floods. And provided we are notified of all loss on or before the said date of September first and are given an opportunity to inspect the stock if we so desire.

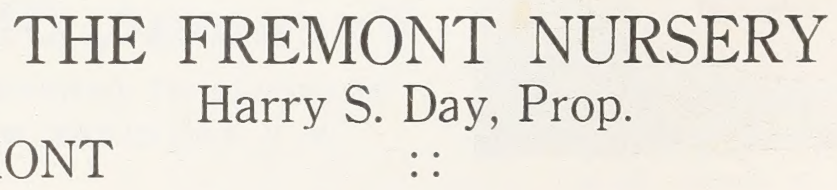




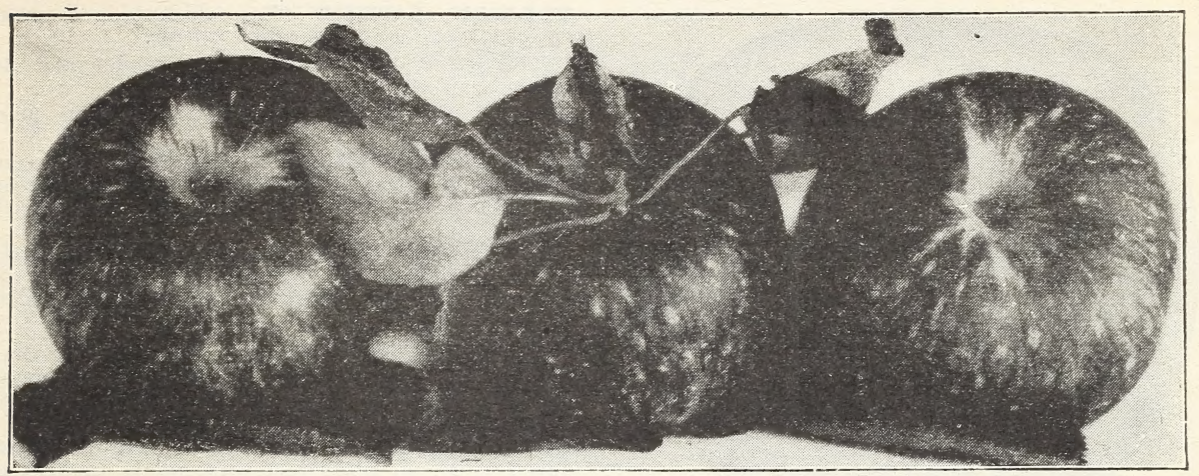

Duchess of Oldenberg

\section{APPLES, THE KING OF FRUITS}

Everyone realizes the great value of apples, both from the standpoint of health and profit.

Why should you pay $10 \mathrm{c}$ each for apples shipped a thousand miles when you can grow better ones and have them fresh, right in your back yard or on your farm.

We grow a large list of varieties covering all demands and tastes, but will not take space to list all or to give a long description of any. Most of the varieties in general cultivation are too well known to make it necessary and most of the leading varieties either for home use or for market are still the old time tried and tested varieties.

\section{SUMMER VARIETIES}

FARIY HARVEST-The old fashioned early harvest apple.

GOIDEN SWEFT-Large, greenish yellow, prolific.

RED ASTRACHAN-The old red harvest apple. SWPET BOUGH-Large yellow.

YIIIOW TRANSPARENT-Tree very hardy. Bears young. The leading early commercial variety.

\section{FALL VARIETIES}

DUCHESS OF OIDFNBURG-Large striped red variety. Young and prolific bearer. The leading late summer or early fall sort.

FAMEUSE-(Snow). Flesh snowy white, sometimes called the Snowflake. Will keep till Janu. ary. Sometimes classed as a winter variety.

MAIDEN'S BIUSH-Yellow with a blush on one side. Splendid quality.

WEAITHY-The best all around Fall variety for all purposes. Bears very young and annually. Tree very hardy. Quality the best. We also have Fall Pippin, Munson Sweet and Pumpkin Sweet.

\section{WINTER VARIETIES}

BANANA (Winter Banana)-Large yellow with red blush. Named because of its delicate banana. like fragrance.

BAIDWIN-Everybody knows this old favorite. Still one of the leading sorts.

BEN DAVIS-So does every body know this variety. Hardy tree, heavy bearer, long keeper but of poor quality.
DFxICrous - A newer variety now thoroughly tested in all localities. Large size, fine appearance, being a beautiful dark red color. Very aromatic and pleasant to the taste. One of the leading market sorts.

FAIIAWATER-The old-fashioned Pound ap. ple. Yellowish green.

GANO-An improved Ben Davis, being a deep red instead of a striped variety.

GRIMIS GOIDEN-Another of the old varieties still classed among the leaders. Golden yellow, exceptionally fine flavor. Claimed to be susceptible to collar rot. We can furnish double worked trees of this variety if desired.

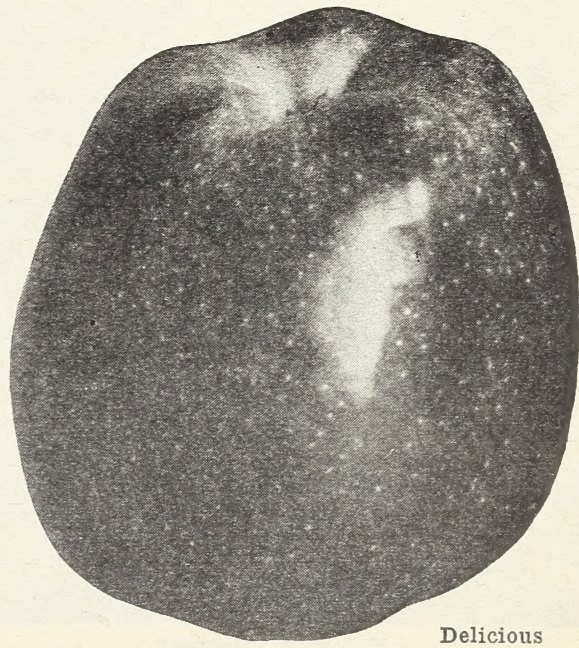




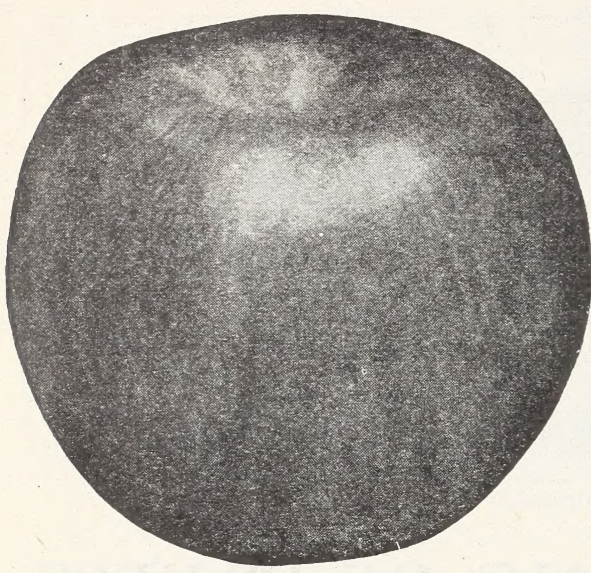

Jonathan

FUBBARDSON-Good size and quality. Yellow striped with red.

JONATHAN-Medium size but of the very best quality. An early and annual bearer. Possibly the leading market variety.

McINTOS. RED-An improved Snow, which keeps much longer. Another leader. The best appearance and quality.

NORTHERN SPY-Another one known to all for its fine quality and beautiful stripped red color. Late coming into bearing but makes up for that after it begins.

NORTHWESTERN GREENING-Fruit similar to R. I. Greening but a much longer keeper and tree a far better and stronger grower.

RAMBO-Medium size, streaked and mottled yellow and red.

ROME BEAUTY-The leading sort in Southern Ohio, its native home, but does well anywhere. Large, yellow, striped with bright red. Good keeper.

RHODF ISTAND GREFINING-Large greenish with yellow cast. Fine flavor.

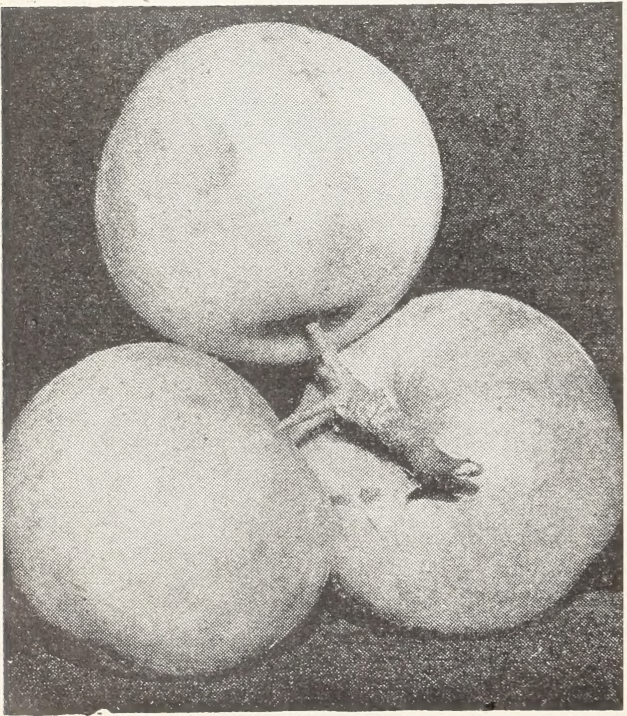

Yellow Transparent
TOIMAN SWRET-The old-fashioned sweet variety much used for apple butter.

KING (Tompkins Co.)-Large, tender and fine quality. Yellowish striped with red.

STARK-Resembles Baldwin. Tree bears much younger.

STAYMANS WINESAP-Planted very extensively as a commercial variety. Good size, green. ish with red stripes. Crisp and juicy and a good keeper.

WAGFNER-The youngest bearer of all, sometimes bearing in the nursery row. A good old fashioned favorite. Striped red and best quality. A good keeper.

We have also Baltimore, Chenango, Roxbury Russet, Spitzenburg, Seek No Further, Winesap, Yellow Belleflower, Domine, Sutton Beauty Golden Russet, Red Spy and others.

COURTIAND-An improved McIntosh intro. duced in N. Y. State and very highly thought of Similar to McIntosh but hangs on the tree bet. ter. Also a better shipper than MeIntosh.

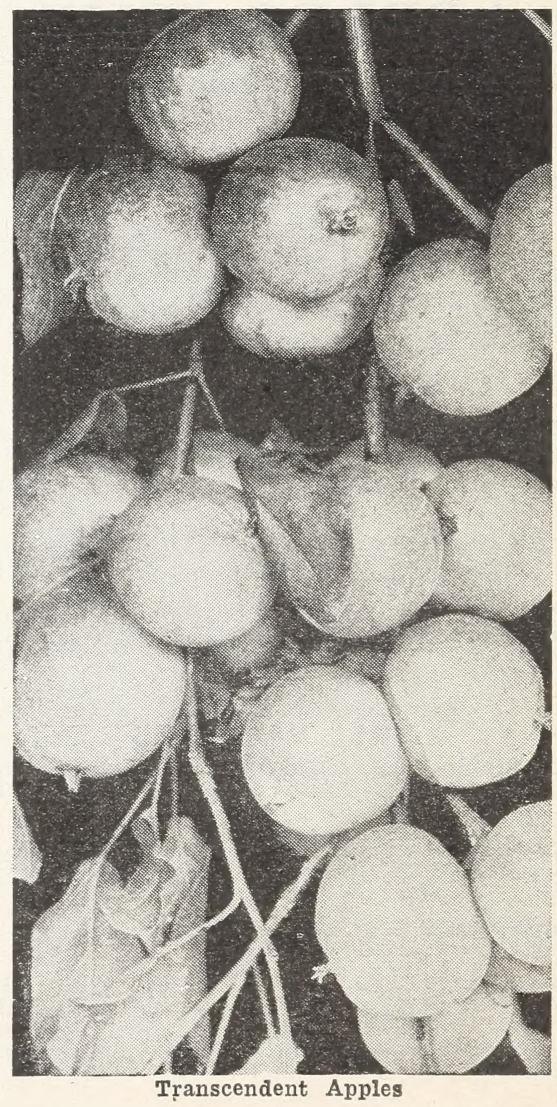

\section{CRAB APPLES}

All the crab apples we offer are large size, as large as a small sized apple.

HYSIOP-Very dark crimson when ripe. Heavy bearer. The leading crab.

TRANSCENDENT-Earlier than the above. Yellow striped with red. Very juicy.

WHITNEY-Large size. Green striped with red. Heavy bearer and especially valuable for cider making. 


\section{Price List of}

\section{The Fremont Nursery}

At the Nursery or by Express or Freight, Purchaser Paying Charges.

\section{Season 1928}

For first class stock, well rooted and delivered in prime condition.

VARIETIES NOT LISTED-It is not possible to list in either our catalogue or this price list, all the kinds and varieties of trees and plants that we can supply. If you wish anything which you do not find listed please write us for quotations.

PRICES-Are for the regular No. 1 grade of size specified. We reserve the right to charge extra for stock personally selected at the nursery, or for trees of extra heavy grade, or for scarce varieties when ordered alone.

In order to be fair to the small purchaser as well as the large we give a single, ten and 100 rate. Five trees or plants of the same variety and size will be furnished at the 10 rate. 25 will be furnished at the 100 rate. Less than 5 plants of one variety and size must be figured at the single rate and 5 to 25 plants of a single variety and size at the 10 rate.

PACKING CHARGE-Owing to the low single rate in many cases, and to the high cost of labor and materials for packing, all orders for less than $\$ 1$ must contain 25c additional for packing same.

TERMS-Cash or satisfactory reference. If you will give us a good sound reference we will ship your order and let you pay for it on receipt. We cannot send orders promiscuously to unknown parties without cash or reference.

PARCEL POST-All small parcels can be sent by mail cheaper than by express. Postage charges must be paid by the purchaser.

SHIPPING DIRECTIONS-Always give full name and address and state how the shipment is to be sent. All small packages should be sent by express or mail and berry plants should never be sent by freight.

LARGE ORDERS-Special quotations will always be made on large orders. Write us stating the quantity desired and the probable varieties.

COMPLAINTS-All complaints for shortages, or damage to stock must be made to us immediately on receipt of goods and no complaint will be considered unless made within 10 days of receipt of stock.

FREE-For every order of $\$ 10$ or for each additional multiple of $\$ 10$ we will give free one extra tree or shrub or both. State which you want. The selection must be left to us but only good stock will be used.

VISITORS-Are always welcome and are invited to our nurseries. 
APPLE AND CRAB APPLES

General List.

Each Per 10 Per 100

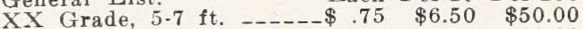

First Class 4.6 ft.

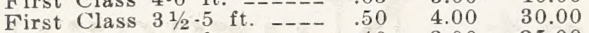

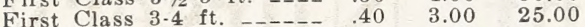

1 yr. Whips $3-5 \mathrm{ft}$. $\ldots \ldots . .40 \quad 3.50 \quad 30.00$

DWARF APPLE

First Class 3.5 ft.

First Class 2-3 ft.

\section{STANDARD PEARS}

XX Grade 5-7 ft. _...- $\quad .75 \quad 7.00$

First Class 4-6 ft. -

First Class $3 \frac{1}{2}-5 \mathrm{ft} . \ldots .50 \quad 4.00$

First Class 3-4 ft. ..... .40 3.50

\section{DWARF PEARS}

First Class 3.4 ft.

First Class $2-3 \mathrm{ft}-60-5.50$

\section{PEACHES}

XX Grade 5-7 ft.

First Class 4-6 ft. -..- $.40 \quad 3.50$

First Class 3-4 ft. $\ldots \ldots . .35 \quad 3.00$

First Class 2-3 ft. $\ldots \ldots \ldots .25 \quad 2.00$

Irey-5c per tree extra.

\section{SOUR CHERRIES}

XX Grade 4-6 ft.

$\begin{array}{llll}\text { First Class } 31 / 2-5 \mathrm{ft} .--- & .65 & 6.00 \\ \end{array}$

First Class 3-4 ft. - - $\quad .50 \quad 4.00$

First Class 2-3 ft. $\ldots-\ldots-.40 \quad 3.00$

\section{SWEET CHERRIES}

XX Grade 5-6 ft. -..-- 1.00

First Class $4.5 \mathrm{ft}$.

9.00
8.00

First Class 3.4 ft. $\quad .75 \quad 7.00$

First Class $2 \frac{1}{2}-3$ ft. - - $\quad .50 \quad 4.00 \quad 35.00$ tree.

\section{PLUMS}

XX Grade 5-7 ft. First Class 4.6 ft. $-\ldots-.65 \quad 5.00 \quad 40.00$ $\begin{array}{lllll}\text { First Class } 31 / 2-5 & \mathrm{ft} .-- & .50 & 4.00 & 35.00 \\ \end{array}$ First Class $3-4$ ft.
We wish to call especial attention to the maller grades of Pear, Plum, Cherry and Quince, as they are extra fine little trees with exceedingly fine roots.

\section{APRICOTS}

First Class 4-5 ft. $\ldots \ldots \ldots .75 \quad 6.50$

First Class 3-4 ft.

\section{QUINCES}

XX Grade 4-5 ft. - _-_-_ $1.00 \quad 8.50$

First Class 3-4 ft. _..._. .75 6.50

First Class $2-3$ ft. $\ldots .--.60$

\section{MULBERRY}

New American 5.7 ft. -- $1.00 \quad 9.00$

New American 4-5 ft. $\quad-\quad .85 \quad 7.50$

Black English 5.7 ft. -..- $\quad .85 \quad 7.50$

Russian 4.6 ft. ...... $.60 \quad 5.00$

Russian $3-4 \mathrm{ft}$. The smaller sizes of all fruit trees can be sent by mail.

\section{NUT TREES}

$\begin{array}{llll}\text { Butternut, } & 4-6 \mathrm{ft} . & ---- & .75 \\ \text { Butternut, } 3.4 \mathrm{ft} & ----- & .65\end{array}$

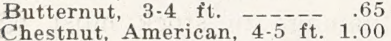
Chestnut, American, 3-4 ft. .75 Filbert, American, 4-5 ft. 1.00 Filbert, American, 3-4 ft. .75

Filbert, English, 3-4 ft. -- 1.00

Walnut, Black, 4-6 ft. _.. .75

Walnut, Black, 3-4 ft. ... .65

Walnut, Japan, 4-6 ft. -- 1.00

Walnut, Japan, 3.4 ft..- .75

Walnut, English, 3-4 ft. -1.25

Walnut, English, 2-3 ft. 1.00

75.00 60.00

45.00

75.00
GRAPES, Two Year

Each Per 10 Per 100

Agawam _.

Brighton - $\begin{array}{rrrr}30 & 2.50 & 20.00\end{array}$

Campbells Early _-_-_- $.30 \quad 2.50 \quad 20.00$

$\begin{array}{llll}\text { Catawba } \ldots \ldots & .25 & 2.00 & 12.00\end{array}$

Concord _.

Delaware

Diamond _...

Moore's Early _...

Niagara - $-.25 \quad 2.00 \quad 10.00$

Pocklington _.

Salem _...

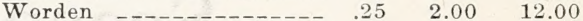

Wyoming Red _...... $\quad .30 \quad 2.25 \quad 18.00$

Agawam GRAPES, One Year $1.50 \quad 10.00$

Brighton -

Catawba

Concord

Delaware _.......... $\quad .25 \quad 2.00 \quad 18.00$

Diamond

Moores Early _... $\quad .20 \quad 1.50 \quad 10.00$

$\begin{array}{llll}\text { Niagara } \ldots .20 & 1.25 & 8.00\end{array}$

Pocklington _...

Salem _..._.

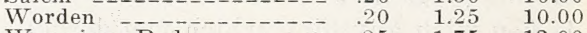

$\begin{array}{llll}\text { Wyoming Red } \ldots & .25 & 1.75 & 12.00\end{array}$

CURRANT, Two Year

Perfection _-

Other Leading Varieties:

Fays, Cherry, Wilder, ete $.20 \quad 1.50 \quad 12.00$ GOOSEBERRY, Two Year

$\begin{array}{lllll}\text { Ilowning \& Houghton } & -- & .25 & 2.00 & 15.00\end{array}$

Josselyn _.

\section{RASPBERRY}

Per 10 Per 100 Per 1000

Cuthbert, King, St. Regis $.50 \quad 3.00 \quad 22.00$

Cumberland and Gregg - $\begin{array}{llll}.50 & 2.50 & 16.00\end{array}$

New Logan _._.

$\begin{array}{llll}\text { Columbian and Haymaker } & .75 & 5.00 & 40.00\end{array}$

Latham _.. $1.00 \quad 6.00 \quad 50.00$

\section{BIACKBERRY}

Snyder, Taylor, Erie $\begin{array}{rrr}60 & 4.00 \quad 30.00\end{array}$ $\begin{array}{llll}\text { Eldorado and Blowers -- } & .75 & 5.00 & 40.00\end{array}$

Lucretia

\section{DEWBERRY}

STRAWBERRY

Per 10 Per 100 Per 1000

Mastodon Everbearing - $\quad .60 \quad 4.00 \quad 25.00$

Other Everbearing _- $\quad .40 \quad 2.00 \quad 15.00$

$\begin{array}{llll}\text { Cooper \& Chesapeake } \ldots-- & .30 & 1.50 & 10.00\end{array}$

S. Dunlap \& Warfield $--\quad .25 \quad 1.00 \quad 6.00$

Gibson \& Premier _-.-- $\quad .25 \quad 1.00 \quad 6.00$

Other varieties _..... $\quad .25 \quad 1.00 \quad 7.00$

Asparagus, 1-year ROOTS $20 \quad 1.00 \quad 8.00$ Asparagus, 2-year - $\begin{array}{rrrr}.30 & 1.50 & 12.00 \\ \text { Each } & \text { Per } 10 & \text { Fer } 100\end{array}$

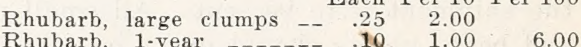

\section{HEDGE PLANTS}

Thunberg's Barberry, Each Per 10 Per 100 $12-18$ in. bushy _._. $\quad .25 \quad 2.00 \quad 14.00$

Thunberg's Barberry,

18.24 in., bushy _..- $\quad .30 \quad 2.50 \quad 20.00$

Thunberg's Barberry,

24-30 in., bushy

Barberry, Red Leef, 12.15

Barberry, Red Leaf, $15-18 \quad .75 \quad 7.00$

Calif. Privet, $12-18$ in. $-\quad .10 \quad .75$

Calif. Privet, $18-24$ in. $--.15 \quad 1.00$

Calif. Privet, 2-3 ft. $---\quad .20 \quad 1.50$

Ibota Privet, more hardy

12.18 in. -

Ibota Privet, 18.24 in.

1.25

1.50

Ibota Privet, $2-3$ ft. $\ldots .-.25 \quad 2.00$

Regals Privet, 18.24 in.-- $.30 \quad 2.50$
30.00

5.00

7.00

8.00

10.00

12.00

14.00 


\section{ORNAMENTAL TREES}

Aralia, Spinosa (Devils Walking Each Per 10 Stick) $6-8$ ft. Same, 8-10 ft.

Birch, American White, 7-8 ft. -- 2.00 Birch, Cut Leaf Weeping, 3-4 ft. 1.75 4.6 ft. $6-8$ ft. -

Catalpa, Bungeii (Umbrella Catalpa) $4-5$ ft. stem _-_$5-6$ ft. stem $6-8 \mathrm{ft}$. stem

Catalpa Speciosa (Flowering Catalpa) 6.8 ft. _.8.10 ft 1.25

Cherry, Flowering, 3-4 ft. Cherry, Weeping, 2-yr. heads _... 5.00

Crabs, Flowering, 2-3 ft. _...-- 1.00 $3-4$ ft. -

Floribunda, Scheideckeri, and Atrosanguinea, 4-5 ft. ...--- 1.50

Cornus, Florida, Dogwood, $3-4$ ft. 1.00 $4.5 \mathrm{ft}$. Cornus, Florida Rubra (Red Flowering Dogwood) 2 ft. - -2.50

Elm, American, 6.8 ft. $\ldots \ldots-\ldots 1.25$ 8-10 ft. 10 ft. 1.75 $10-12$ ft. $11 / 2.2$ in. caliper $2-3$ in. caliper _. Horse Chestnut, $5-6 \mathrm{ft}, \ldots$

Koelreuteria, 4-5 ft. _-_-_..-- 1.50

Linden, American, 6.8 ft. _..-- 1.50 $8-10 \mathrm{ft}$.

Linden, European, 6-8 ft. $\ldots \ldots \ldots-2.00$ $8-10 \mathrm{ft}$.

Larch, European, 4-6 ft. $6-8 \mathrm{ft}$.

Liquidamber, $5-6 \mathrm{ft}$.

Maple, Ash Leaved (Box Elder) $6-8 \mathrm{ft} . \mathrm{ft}, 00$ $8-10 \mathrm{ft} . \mathrm{c}-1.50$ $11 / 2$ inch -2 . 2.50

Maple, Ginnala (Dwarf Amur Maple) $3-4$ ft.

Maple, Japanese, Red Leaf Seed-

lings, 15.18 in. 18.24 in.

Blood Leaf, Grafted, 18.24 in.

Blood Leaf, Grafted, 2-3 ft. _-_-10.00

Ashio-Beni, grafted, the best red, $18-24$ in. very bushy

Maple, Norway, 6-8 ft. $8.10 \mathrm{ft}$.

Maple, Schwedlers, 6-8 ft. $8-10 \mathrm{ft}$.

Maple, Sugar, 6.8 ft. 'L_... 1.50 $8-10$ ft. $10-12$ ft. $11 / 2-2$ in cal

Maple, Silver, $6-8 \mathrm{ft}$ $8-10$ ft. $10-12 \mathrm{ft}$.

Maple, Sycamore, 6-8 ft.

Maple, Wiers Cut Leaf, $6-8 \mathrm{ft}$ - 1.50

Mountain Ash, 5-6 ft. $6.8 \mathrm{ft}$. $8.10 \mathrm{ft}$.

Mulberry, Teas, Weeping

Oak, Pin, 6.8 ft. $8.10 \mathrm{ft}-3.50$

Poplar, Carolina, 6.8 ft. $8.10 \mathrm{ft}$. $10-12 \mathrm{ft}$.

Poplar, Lombardy, $6.8 \mathrm{ft}$. .75 8.10 ft. _.. 1.00

Poplar, Bolleana, 6-8 ft.

Poplar, Simoni, 8-10 ft. _.....- 1.25

Prunus, Newport, $3.4 \mathrm{ft}$.

Prunus, Pissardi, 3-4 ft.

Prunus, Triloba, 3-4 ft. 1.25 $4-5 \mathrm{ft}$.

Fach Per 10

Red Bud, 3-4 ft. $\$ 1.00$

4-5 ft. - 5 .

Sycamore, European, 6-8 ft. $\ldots \ldots 1.5014 .00$

15.00

17.50

7.50

10.00

9.00

10.00

10.00

15.00

9.00

20.00

25.00

25.00

35.00

14.00

18.00

27.50

11.00

13.50

4.50

6.50

Spirea, A. Waterer \& Callosa

Alba, $12-15$ in., bushy $\ldots \ldots \ldots$

18-24 in., bushy

Spirea, Froebels, $18-24$ in. 24-30 in.

Spirea, Prunifolia, 2-3 ft. 3-4 ft. Thunbergi, $\mathbf{1 2 \cdot 1 8}$ in. 18.24 in. . 24-30 in.

Almond, Flowering, $2-3$ ft.

$2-3 \mathrm{ft}$.

3-4 ft.

Berberry-See Hedge Plants.

thia, Inter. Spectabilis

Privet-See Hedge Plants.
$8-10 \mathrm{ft} . \ldots 2.00 \quad 18.00$

Thorns (Hawthorn) $4-5 \mathrm{ft}$ $5-7 \mathrm{ft}$.

Tulip Tree, $6-8 \mathrm{ft}$

Willow, Babylonica, $6.8 \mathrm{ft}$.

Willow, Niobe, $6.8 \mathrm{ft}$.

Willow, Pussy, 3-4 ft.

$4.5 \mathrm{ft}$.

Willow, Wisconsin, 6-8 ft. $\ldots$

Fine, well rooted, specimen plants of the size usually sold for No, 1 grade. Can furnish smaller mailing size, nice plants of all shrubs -half the single rate, plus postage.

Each Per 10

Amorpna, Fruticosa - - - - - .5

Azalea, Mollis, 15.18 inch

Butterfly Bush, strong plants _- . $40 \quad 3.00$

Calyeanthus, Floridus $-.50 \quad 4.50$

Colutea, Arborescens - $-5.50 \quad 4.00$

Spaetha Aurea, $2-3 \mathrm{ft} .------\quad .75 \quad 6.50$

Paniculata \& Lutea

Other varieties $-40-3.50$

12.15 inch spread -18 inch spread 1.50
15.00

Cydonia, Japan Quince, _._--_- .60

Deutzia, Gracilis, $12-15$ in. $\ldots---.40$

Deutzia, I emoine, $18-24$ in. -.50

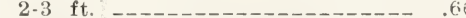

Deutzia, other varieties, $3-4 \mathrm{ft}$. --.50

Elder, Golden

Euonymous, Alatus _...

Forsythia, other varieties, $3-4 \mathrm{ft}$. $\quad .50$

Fringe, Purple or White, 2-3 ft.-- 1.00

Honeysuckle, Upright, $3.4 \mathrm{ft}-\ldots-.40$

Hydrangea Ar. Gd. (Hills of Snow)

Hydrangea Ar. Gd. (Hills of Snow)

$2-3 \mathrm{ft}$.

Hydrangea, P. G. $18-24$ in. - - $.50 \quad 4.00$

Kerria, Double or Single

Lilacs, Rothomagensis \& Persian _- $.75 \quad 6.50$

Lilacs, Named French, 18-24 in. - $\quad .75 \quad 6.50$

Lilacs, Named French, $2.3 \mathrm{ft} \ldots-1.00$

Rhodotypos, White Kerria, 2-3 ft. $.50 \quad 4.00$

Rhus (Sumae) Leading varieties $.50 \quad 4.00$

5.00
3.50

4.00

4.00

5.00
3.50

4.00

3.50

6.50

3.50

4.00

3.50

4.00

.56

5.00

5.00

6.50

5.00

3.00

4.00

5.00

3.50

4.00

4.00

5.50

3.00

4.00

5.00 
Each Per 10

Spirea, Van Houtte, 18-24 in._-_- $\$ .25 \$ 2.00$ $2.3 \mathrm{ft}$. $3.4 \mathrm{ft}-50-5.00$ $4-5 \mathrm{ft}, \ldots .60 \quad 5.00$

Spirea, Sorbaria, $2-3 \mathrm{ft}$.

Spirea, other varieties, $2-3$ ft. $\ldots .-40$

Spirea, other varieties, $3-4 \mathrm{ft}$... .50

Stephenandra

Snowberry, Red or White, 2-3 ft. .40

Snowberry, Red or White, 3-4 ft. .50

Syringa (Philadelphus) Golden Leaf, $12-15$ in. $15-18$ in. $18-24$ in. - .75

Syringa, Bouquet Blanc, 18.24 in. .75 $2-3$ ft. _Syringa, Virginalis, $2-3 \mathrm{ft}$. $3-4$ ft. Syringa, Grandiflora, Mt. Blanc \& Coronarius, $2.3 \mathrm{ft}$. ........ .40 3-4 ft. -

Tamarix, Africana, $2-3 \mathrm{ft}$

Tamarix, Hispida, 2-3 ft. -..---iburnum, Carlesi, $3-4 \mathrm{ft}$. high and about 3-4 ft. broad Small plants, $12-15$ in.

Viburnum, Cassinoides, $2-3$ ft. --1.00
Viburnum, Plicatum, 2-3 ft. - - 1.00

Viburnum, Opulis \& Steriles, 18-24 in. _... 50

Viburnum. Opulis \& Steriles $2-3 \mathrm{ft}$. Viburnum, other varieties $2-3 \mathrm{ft} . \quad .75$ $3-4 \mathrm{ft}$. Weigela, Eva Rathke, 18-24 in.- $\quad .50$ $2-3 \mathrm{ft}$. Weigela, Variegated Leaf, 18-24 in. $\quad .50$ Weigela, other varieties, 2-3_... .40

Weigela, other varieties, 3-4 ft.-- .50

\section{FARDY VINES}

Ampelopsis, Veitchii, Boston Ivy_- .50

Dutchmans Pipe, True _._. 100

Bittersweet _._. .40

Clematis, Paniculata

Clematis, Large Flowered _._._. .85

English Ivy $\quad .850$

Honeysuckle, Scarlet Trumpet _- $\quad .50$

Honeysuckle, Monthly Fragrant -- .50

Other varieties $\quad .40$

Lycium, Matrimony Vine _... .40

Polygonum, Silver Lace Vine

Wisteria, Seedlings _..._..... .50

Wisteria, Grafted Stock 1.00

\section{FVFRGRFEN}

Specimen Trees, with roots Balled and Bur. lapped.

Arbor Vitae:

Each

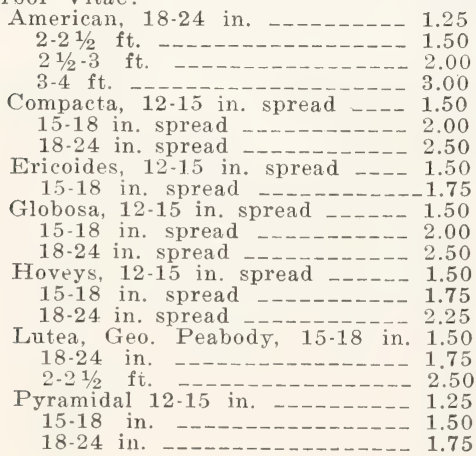

6.50

6.50

8.50

6.50

3.00

4.00

3.50

4.00

5.00

8.50

8.50

4.00

5.00

7.00

8.50

4.50

6.50

4.00

3.50

4.00
Pyramidal

$\begin{array}{ll}2-2 & 1 / 2 \\ 2 & \mathrm{ft}\end{array}$

Each

$3-4 \mathrm{ft}$.

$\$ 2.50$

4.50

Siberian, $12-15$ in.

$15-18$ in.

$18-24$ in. -

4.00
4.00
3.50 $\quad$ Woodwards, $12-15 \mathrm{fin}$

3.50 Woodwards, $12-15$ in. $15-18$ in.

$18-24$ in.

4.00 Oriental Arbor Vitae (Biotas):

$5.00 \quad$ Oriental, 18-24 in.

$2-2 \mathrm{I} / \mathrm{2} \mathrm{ft}$.

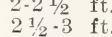

$10-12$ in -1.50

$12-15$ in.

Oriental Nana Aurea (Berck-

mans Golden Arbor Vitae)

$12-15$ in. -

$15-18$ in. -

Oriental, Bakeri, 10-12 in. $\ldots-1.50$

$12-15$ in. -

Oriental, Compacta, 10-12 in. - 1.50

$12-15$ in. -

Oriental Pyramidal, $12 \cdot 15$ in. --1.50 Fir: $15-18$ in. -

Balsam, 15-18 in. - 2.00 $18-24$ in. $2-21 / 2 \mathrm{ft}$.

Connolor, $12-15 \mathrm{ft}$. 3.00 $15-18$ in. $18-24$ in.

Douglas, $18-24$ in. $2-2,1 / 2$ ft. . 3.00 $21 / 2-3 \mathrm{ft}$. $3-4 \mathrm{ft}$. - . 5.00

Juniper:

Chinensis, $15-18$ in. _-_._- 2.00 18.24 in. $2-21 / 2 \mathrm{ft}$.

4.00 Chinensis Mascula, 15-18 in -2.25 $18-24$ in.

Communis, 15.18 in. 18-24 in

Communis Aurea, 15-18 in. - 2.50 18-24 in.

English 15-18 in. $18-24$ in. $2-21 / 2 \mathrm{ft} . \ldots$

Horizontalis, $15-18$ in. spread -2.25 18-24 in. -

Horizontalis, Glauca 15-18 in. spread _. 18-24 in. spread _... 3.50

Irish, $15-18$ in. $18-24$ in. $2-21 / 2 \mathrm{ft}$. $21 / 2-3$ ft. - .

Neboriense, $15-18$ in. 18.24 in. $2-21 / 2$ ft. -

Pfisteriana, 15-18 in. spread - 2.00 18-24 in. spread _. $2.2 \frac{1}{2} \mathrm{ft}$. spread $21 / 2-3 \mathrm{ft}$. spread _...

Prostrata, 18-24 in. spread _- 3.00 $2-21 / 2$ ft. spread _...... 4.00 $21 / 2-3$ ft.

Sabina, $15-18$ in. $18-24$ in. $2-21 / 2$ ft. ..... 4.00

Silver, 2-3 ft., -

Stricta (Excelsa) $12-15$ in. - -2.00 15.18 in. 18.24 in.

Stricta, Variegata, $12-15$ in. -2.00 15.18 in.

Swedish, Tall Growing, $15-18$ in. 1.50 $\begin{array}{lll}18-24 & \text { in. }-\ldots & \\ 2-21 / 2 & \text { ft. } & \end{array}$ 


Swedish, Dwarf, $15-18$ in. $\quad \begin{aligned} & \text { Each } \\ & \$ 1.50\end{aligned}$

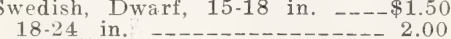
$2.21 \% \mathrm{ft}-2.50$

Tamariscifolia, 12.15 in. spread 2.00 15-18 in. spread _..._... 3.00 13.24 in. spread

Tripartita, $12-15$ in. $15-18$ in. 18.24 in. 4.00

Virginiana (Red Cedar) 18.24 in. _. 1.50 $2-21 / 2 \mathrm{ft} . \mathrm{ft}$ $2,1 / 2-3$ ft. _... $3.4 \mathrm{ft}, \ldots$

Virg. Glauca, 15.18 in. 18.24 in. $2.2 \frac{1}{2}$ ft. - . $21 / 2-3$ ft. ….... 4.00 $3-31 / 2$ ft. _... 5.00 4.5 ft. (sheared) -

Virg. Cannarti, $15-18$ in. - --3.00 18.24 in.

Waukegan, 15.18 in. spread -2.25 18.24 in. spread _......... 2.75 Pine:

Austrian, 18.24 in. _... 2.00 $2-3 \mathrm{ft} . \mathrm{ft}$ 3-4 ft. -

Mugho, Dwarf, $10-12$ in spread _... 2.00 $12-15$ in. spread _...... $15-18$ in. spread 18-24 in. spread _......... 4.00

White, 18.24 in. $2-3$ ft. -... $3-4$ fi. -

Scotch, $15 \cdot 18$ in. $18 \cdot 24$ in. $2-3$ ft. . - 3.00

Retinospora:

Filifera, $12-15$ in. $15-18$ in. $18-24$ in. $3.4 \mathrm{ft}$. spread - 6.00

Obtusa, $15-18$ in. $18-24$ in. -

Ohtrisa Crippsi, 12-15 in. 15.18 in. - 2.50 18.24 in.

Obtusa Gracilis, 15.18 in. $18-24$ in -2.00

Ob. Gracilis Aurea, 15.18 in 2.50 $18-24$ in. -

Ob. Nana Compacta, $12-15$ in. -3.00

Pisifera, $15-18$ in. 18.24 in. $2 \cdot 2 \frac{1}{2} \mathrm{ft}$.

Pisifera Aurea, 15.18 in. 18.24 in. … $2 \cdot 2 \frac{1}{2} \mathrm{ft} . \mathrm{n}$

Plumosa, $12-15$ in. 15.18 in. $18-24$ in. $2-21 / 2$ ft. ....... 3.00

Plumosa Aurea, $12-15$ in. $\ldots \ldots-\ldots 1.50$ 15.18 in. $18-24$ in. $2-21 / \mathrm{ft}$. .

Squarrosa Veitchii, 12.15 in. -2.00 $15-18$ in. $18-24$ in.

Squarrosa Sulphurea, $\mathbf{1 5}-18$ in. 2.50 18.24 in. - _ . Spruce:

Black Hills, 15-18 in. _._._. 2.00 18.24 in. ....... $2.21 / 2 \mathrm{ft} . \ldots \ldots$

Colorado Green, 15.18 in. 18.24 in. $2 \cdot 21 / 2$ ft. $\ldots \ldots \ldots$ $21 / 2-3$ ft. $3 \cdot 4$ ft.
Colo Each $2-21 / 2 \mathrm{ft} . \mathrm{f}$ $21 / 2-3 \mathrm{ft}$.

Kosters Blue, 18.24 in. $2-21 / 2$ ft. $21 / 2-3 \mathrm{ft} . \ldots \ldots \ldots$

Moerheims Blue (The best of all ) $3-31 / 2$ ft. . $31 / 2-4 \mathrm{ft}$.

Hemlock, 15-18 in. 2.00 18.24 in. - . $2-21 / 2$ ft. $21 / 2-3$ ft.

Norway, $15-18$ in. $18-24$ in. $\ldots \ldots$ $2 \cdot 21 / \mathrm{ft}$. $21 / 2-3$ ft. $3-4$ ft. $4-5 \mathrm{ft}$.

Write for śpecial price on Norway Spruce in 100 or 1000 lots.

Taxus (Yew):

Canidensis, 12.15 in. $15-18$ in.

Capitata, $12-15$ in.

$15-18$ in. $18-24$ in. -

Cuspidata, $12-15$ in. $15-18$ in. $18-24$ in. .

Cus. Brevifolia, 10-12 in., bushy 2.50 $12-15$ in., bushy _...... 3.00 15-18 in., bushy _...... 4.00

Cus. Brev., Improved, 18.24 in. 4.00 Evergreen Shrubs:

Boxwood, 12-15 in., bushy _. 2.00 15-18 in., bushy _$18-24$ in., bushy

Kalmia (Mountain Laurel) 15-18

in. clumps _....... 2.50

Mahonia (Oregon Holly)

$12-15$ in.

$15-18$ in.

$18-24$ in. - 1.00

Pachysandra, 2 yr. $(\$ 2.25$ per 10) - 30

Fhododendrons, clumps, 15-18 in. Carolinianum

Catawbiense

Maximum _..._. 3.00

\section{PERENNIAIS}

Please note that the price of perennials is given per dozen, instead of per 10

All varieties listed in catalog except those given below are: $15 \mathrm{c}$ each, $\$ 1.50$ per 12 .

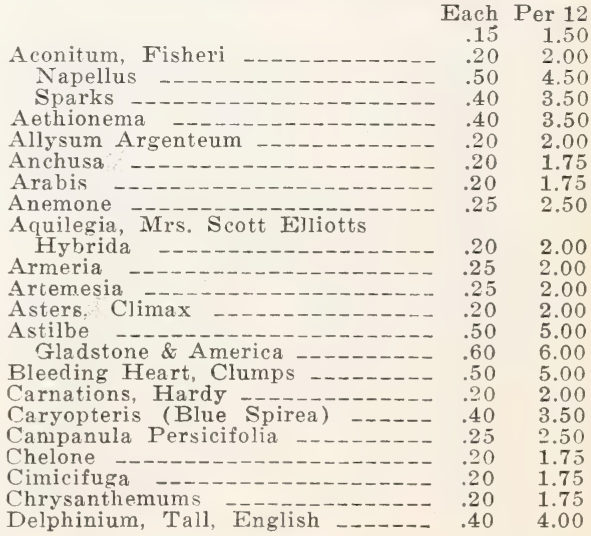


Each Per 12

Delphinium, Nudicadule _._._._ $\$ .40 \$ 3.50$

Desmodium _........ $40 \quad 4.00$

Dictamus _- 404.00

Digitalis, Giant Shirley _._.... $20 \quad 1.75$

Dianthus, Hardy Pinks _...

Eryngium Amethystinum _..._. $.30 \quad 3.00$

Eryngium, Glaucus Roseum _..._. $\quad .20 \quad 1.75$

Funkia _.

Grasses, Ornamental

Gypsophilla, Rokejeka _..._... . .20

Helenium

Helinium, Autumnal Superbum_- .20

Helianthus Multiflorus _... .25

Helianthemum -.. .30

Hemerocallis Flava

Heuchera Brizoides

Hibiscus (Mallows)

Hypericum _...-. .40

Hypericum Reptens _... .50

Iberis _... 20

Iris, Japanese ....................

Lavender (

Liatrus (Blazing Star)

Lobelif _........

Lychnis, Double

Lilies, Auratum _... 30

Candidum _.

Regals _...

Speciosum Album

Speciosum Rubrum _...

Tiger, Double _...

Lupine - .20

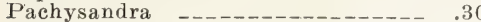

Poppy, Oriental -

Poppy, Mrs. Perry \& Oriflame -- .25

Phlox, Hardy, General List _...- .20

Phlcx, Our selection of varieties _- .15

Phlox, B. Compte \& Crepuscle _..- . .30

Phlox, Brilliant, Commander --- .35

Phlox, Coccinea, Deutchland _-_. .35

Phlox, Feuerbrand, Mrs. E. Pritchard

Paeonies, General List

Paeonies, Felix Crousse

Paeonies, Festiva Maxima

Paeonies, Butterfly, Colleen

Paeonies, Elizabeth, Excelsior _.. 1.00

Paeonies, Fantasy, Hercules … 1.00

Paeonies, Innocense, Invincible -- 1.00

Paeonies, Mars, Marie Jaquin _.. 1.00

Paeonies, MF. Jules Elie, Pompeii 1.00

Paeonies, Regent, Samson _... 1.00

Paeonies, Vesuvius, Winsome
2.00

2.50

2.00

2.00

1.75

2.00

3.00

1.00

3.50

2.00

3.50

4.50

1.75

2.50

2.50

2.00

1.75

2.00

3.00

3.00

4.00

4.00

4.00

1.75

2.00

2.50

1.75

2.50

2.00

1.50

3.00

3.50

3.50

3.50
Paeonies, Waterlily

Fach Per 12

Paeonies, Karl Rosefield _-...- 1.50

Paeonies, Mons. Martin Cahusac 3.00

Paeonies, Sarah Bernhardt _...- 2.00

Paeonies, Venus _._._._._. 1.25

Paeonies, Officinalis Varieties

Paeonies, Officinalis Fringe Leaf $1.25 \quad 12.50$

Plumbago _-_._.

Polyanthus, Yellow

Polyanthus, Verus Hybrids _..._ $.25 \quad 2.50$

Rudbeckia (Golden Glow) -..- $\quad .10 \quad 1.00$

Santolina _.

Saxifrage -

Scabiosa - $25 \quad 2.00$

Sedum _. $25 \quad 2.50$

Statice

Thalictrum _-_-_-_-_-_-_- $\quad .25 \quad 2.50$

Thermopsis _-_._.

Thyme, Coccineum _-_-_-_. $40 \quad 4.00$

Tritoma, Pfitzeri _-_-_-_-_-_ .25 2.50

Tritoma, Other varieties _..... $\quad .35 \quad 3.50$

Trollius, Europeus _-_-__-_- .50 4.50

Trollius, Mixed _. $30 \quad 3.00$

Veronica, Incana \& Spicata

Veronica, Amethystima, Longifolia
and Ruprestris _-

Veronica, Ruprestris Rosea -

Viola (Tufted Pansies) _....... $\quad .20 \quad 2.00$

Viola, Floraire _._._. $25 \quad 2.50$

Viola, Jersey Gem \& Papilio _- $\quad .35 \quad 3.00$

Yucca, Filamentosa _..._._. $.25 \quad 2.50$

Yucca, Variegated Leaf 1 yr. - .- $.50 \quad 5.00$

$\begin{array}{lll}\text { Yucca, Variegated Leaf } 2 \text { yr. strong } & .75 & 7.50\end{array}$

\section{ROSES}

All strong 2 yr. Field Grown. Each Per 10 Alexander Hill Gray _._._. $1.00 \quad 9.00$ Mrs. Calvin Coolidge -

Souv. De Claudius Pernet

Souv. De Georges Beckwith _.- $1.00 \quad 9.00$

Souv. De Geo. Pernet _... $1.00 \quad 9.00$

Souv. De H. A. Verschuren _... 1.009 .00

All others in list _._. $.75 \quad 7.00$

\section{BUIBS FOR SPRING}

Caladium (Elephant's Ear) _._. $25 \quad 2.50$

Cannas, French

Dahlias, assorted colors -

Dahlias, named _......... $\quad .20 \quad 2.00$

Dahlias, fancy, named _._... $\quad .25 \quad 2.50$

Gladioli, assorted colors -

Gladioli, fancy, named

T'uberose

\section{The Fremont Nursery}

HARRY S. DAY, Proprietor Established in 1858 By John Day

FREMONT, - - OHIO

Branches at Dansville, N. Y. and Clyde, Ohio

70 YEARS OF HONORABLE DEALINGS 



\section{CHOICE QUALITY PEARS}

The pear succeeds on most soils but does best on a rather heavy loam. Budded on its own stock it makes what is called a Standard tree; but on Quince stock it makes Dwarf. Standards are best adapted to large permanent orchards; but dwarfs will come into bearing very much sooner and may be planted much closer together. Dwarf must always be planted sufficiently deep to cover the quince stock two or three inches.

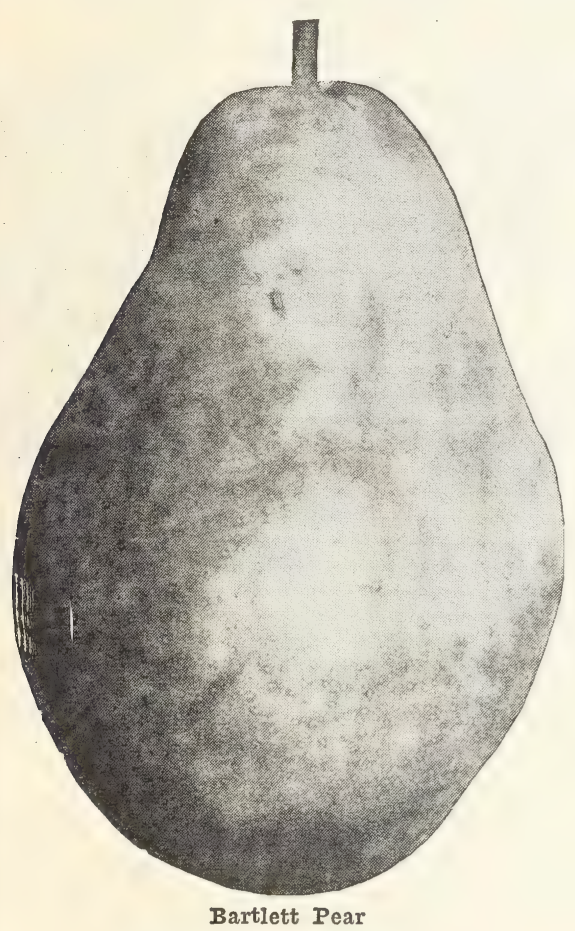

SUMMER PEARS

BARTIETT-Large size, with often a beautiful blush next the sun; buttery, very juicy and high flavored; very popular. August and September.

CLAPP'S FAVORITE-Very large; yellowish green to full yellow when ripe, marbled with dull red in the sun. Vinous, melting and rich. Aug. FARIY WIIDER-Medium size, regular in form; greenish yellow with a brownish red cheek; handsome, melting, sweet, pleasant. First of Aug.

\section{AUTUMN PEARS}

ANJOU-Large, greenish, sprinkled with russet, sometimes shaded with dull crimson; flesh whitist, buttery, melting, with a high, rich, vinous excellent flavor; very productive. October to December.

ANGOULEME (Duchess)-Very large, dull greenish yellow, streaked and spotted with russet; flesh white, and very juicy with a rich and very excellent flavor. Vigorous. October and Novem. ber.

FIEMISH-Large and beautiful; juicy, melting, rich and fine; a good bearer; hardy everywhere. Vigorous. September and October.

CIAIRGraU-Large; skin yellow, inclined to fawn; shaded with orange and crimson, covered with russet dots, flesh yellow, juicy, somewhat granular with a sugary, perfumed, vinous flavor. Moderate. October to December.
KIFFFrR-Very large, bell shaped; light yel. low when fully ripe, sometimes with a slight blush; flesh white, crisp, juicy, of slightly quince flavor; of fair quality; exceedingly valuable for cooking or canning, which brings out its best spicy flavor. Extremely vigorous. October to December.

IAWRENCF-Yellow, covered with brown dots; flesh whitish, slightly granular, somewhat buttery, with a very rich, aromatic flavor, unsurpassed among the early winter pears. November to Jan. uary.

SFCKEI-Small; skin rich yellowish brown with a deep brownish red cheek; flesh very fine grain. ed, sweet, exceedingly juicy, melting; the richest and highest flavored pear known. Moderate. September and October.

SHEIDON-I - Iarge size; yellow or greenish russet, with a richly shaded cheek; flesh a little coarse, melting, juicy, a very brisk, vinous, high. Iy perfumed flavor; productive; vigorous. Oct.

\section{DWARF PEARS}

As certain varieties of Pears are not successful when grown as Dwarfs we herewith give a spe. cial list of such as are most suitable, and of which the Duchess d'Angouleme is decidedly the best of all: Anjou, Clapp's Favorite, Angouleme (Duchess), Kieffer, Louise, Lawrence and Seckel.

Ohio, Jan. 3, 1928.

The bulbs came today and are very nice. Thanks for your kindness. I surely can recommend your nursery to inquiring friends.

MRS. ADELIA WOLFE.

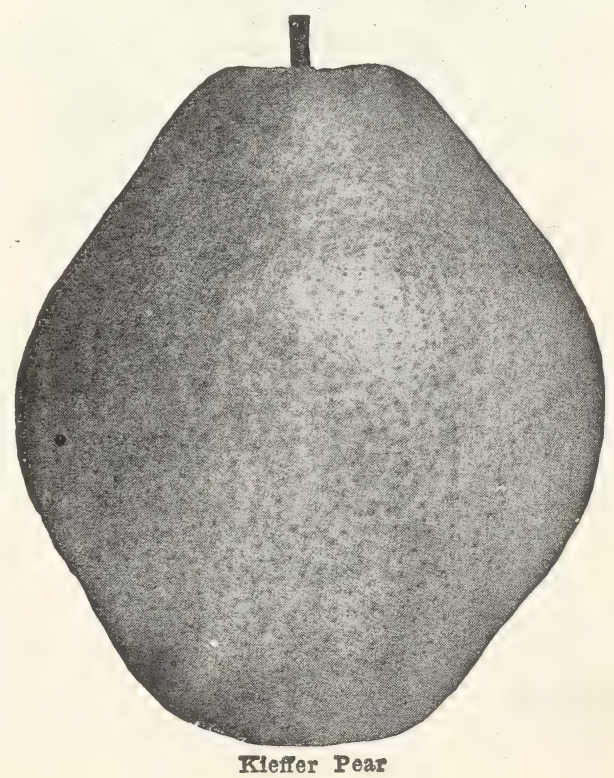




\section{CHOICE PLUMS}

Plums have a distinctive flavor from any other fruit and are especially fine for eating fresh, for jellies, preserves and unexcelled for canning for desserts. Plum trees require no more care than the pear or peach and thrive well under ordinary conditions, however, they do best in a cool, not too dry a place and in good rich soil. Do well planted in poultry yards.

ABUNDANCE-One of the Japan Plums. The tree is a very rapid grower, comes into bearing remarkably young, and yields abundantly. The fruit is full medium size, color a rich cherry red, with a distinct bloom, highly perfumed; flesh light yellow, very juicy and tender. Last of July

BRADSHAW-Fruit very large, dark violet red; flesh yellowish green; juicy and pleasant; very productive. Vigorous. Middle of August.

BURBANK-A valuable Japanese Plum, cherry red with a thin lilac bloom; flesh a deep yellow; very sweet, with a peculiar and very agreeable flavor. The tree is a vigorous grower. August. FIIIFNBURG (Italian Prune)-Medium large; purplish black; blue bloom; free; flesh green, coarse, sweet and pleasant; real bearer and hang on tree after ripening; splendid for drying and market. Tree very productive. September.

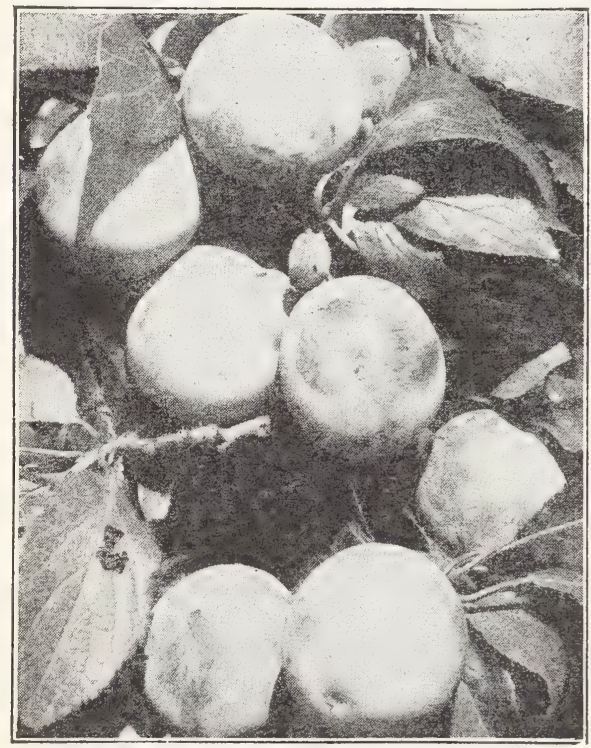

Lombard

GEUII-Fruit very large; deep bluish purple, covered with thick bloom; flesh yellowish green; coarse, sweet and pleasant. Vigoro:s. First to middle of September.

GRAND DU KE-Large; violet red, fine quality, free from rot, very productive. Tree a moderate grower. Last of September.

GERMAN PRUNE-A valuable plum, but most esteemed for drying and preserving. Large, long. oval, purple with a thick blue bloom; flesh firm sweet and pleasant, separating from the stone. Moderate to vigorous in growth. September.

IMPERIAI GAGE-Fruit large, oval, skin pale green, flesh juicy, sweet, rich and excellent. Vigorous. Middle of August.

IOMBARD-Medium, roundish oval; violet red juicy, pleasant and good; adheres to the stone; productive. Nearly always produces a crop. Vig.

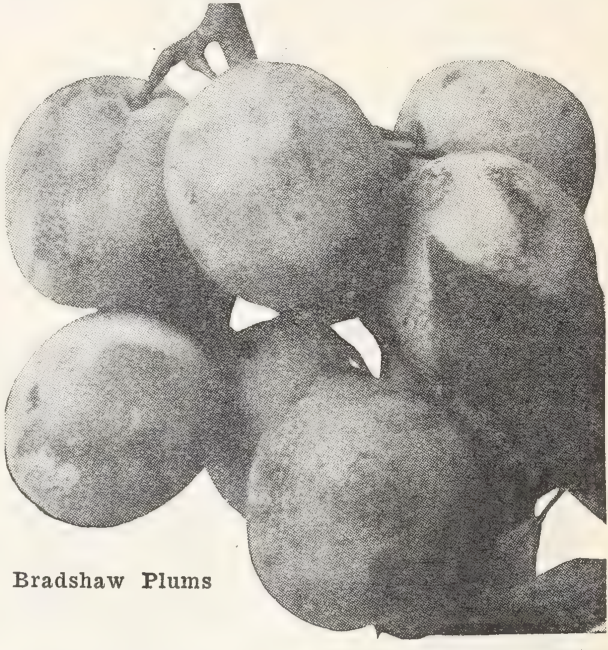

REINE CIAUDE-Nearly round; pale yellow marked with red; juicy, melting and excellent, good bearer. Not liable to rot. One of the most profitable for market. Vigorous. First of September.

SHROPSHIRE-Similar to the old Blue Dam. son but larger. September.

WICKSON-Very large, reddish-purple, with white bloom; cling; flesh firm and meaty; yellow, rich, aromatic. A Japanese variety.

צIILOW $\mathbf{E G G - V e r y ~ l a r g e , ~ e g g - s h a p e d ; ~ e x c e l ~}$ lent for cooking. Vigorous. Last of August.

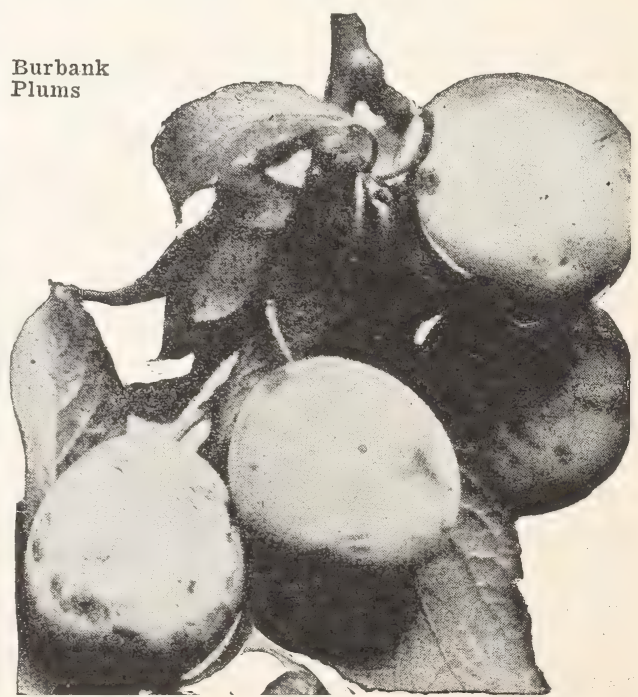




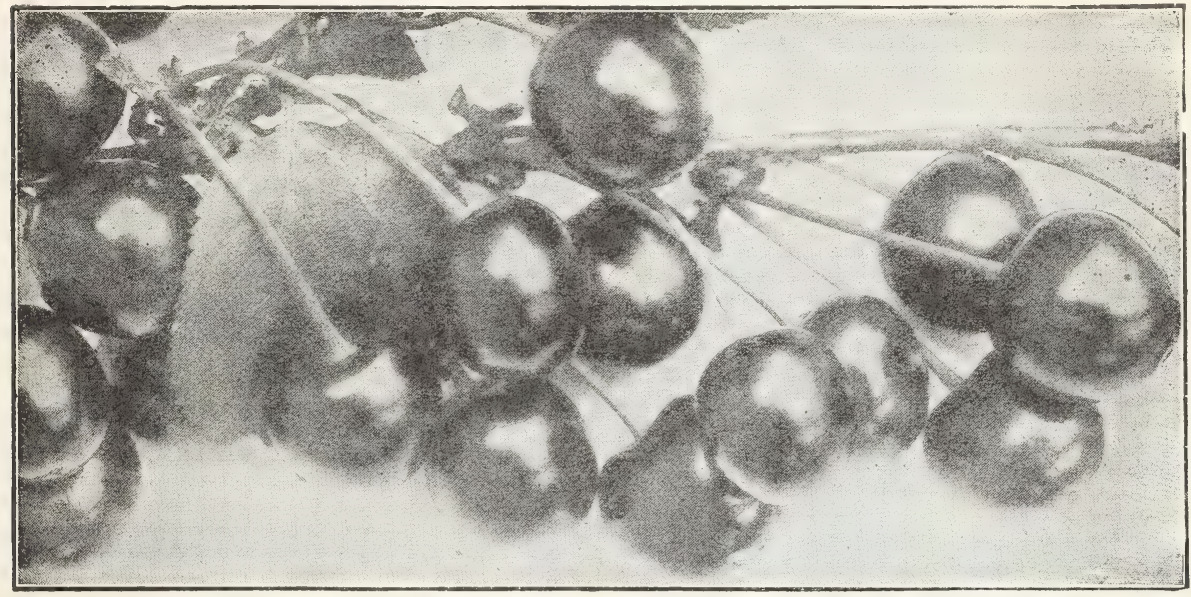

\section{CHERRIES OF QUALITY}

Mazzard root for Sweet Cherries. It is generally conceded now that the mazzard seedling is a better root on which to grow sweet cherries than the Mahaleb on which the sour varieties thrive and on which most cherry trees, both sweet and sour, are grown.

The Mazzard is of the nature of a sweet cherry. It produces many more fine fibrous roots and the sweet varieties seem to grow better, bear better and live far longer when budded on it. Realizing this we have for many years persisted in growing some sweet cherries on Mazzard roots, although it costs considerable more to do it. In our opinion a sweet cherry on this root is worth ten times what one on a Mahaleb root is worth. We can furnish a limited number of all varieties on Mazzard. They cost a little more than others. If you wish them you must specify them.

The Cherry thrives best on a dry, sandy or gravelly soil, and there attains its highest perfection, but will do well in almost any situation except a wet one. We divided them into two elasses: (1) Hearts and Bigarreaus: (2) Dukes and Morellos. The former are strong vigorous growers, making large, open, spreading heads; their fruit is large, heart shaped, meaty and sweet. The Dukes and Morellos do not attain so large size, but are more hardy and less liable to injury from bursting the bark; their fruit is acid or sub-acid.

\section{HEART AND BIGARREAU CHERRIES}

BING-Originated in Oregon. The fruit is very large, dark brown turning to black when ripe and of the finest quality. One of the largest and most delicious sweet cherries grown. Tree strong, stocky, thrifty grower with heavy foliage. Should be followed by Lambert which ripens later.

IAMBERT-Another of the best sweet sorts, originating in Oregon. Dark purplish red turning to jet black when ripe. Extra large, flesh firm and rich. Tree a strong grower, hardy and very productive. A splendid sort to follow Bing.

NAPOLEON-Very large, pale yellow or red; very firm, juicy and sweet; very productive; one of the best. Vigorous. First of July.

SCHMIDT-Remarkably hardy and productive. Fruit grows in clusters and of the largest size; a deep black color; flesh dark, tender, juicy, with a fine rich flavor. Tree hardy. Vigorous. July. SPANISH-Large, pale yellow, with red cheek; firm, juicy and excellent; one of the best light colored cherries; productive. Free. Last of June.

TARTARIAN-Very large, bright purplish black; half tender, juicy, very rich, excellent flavor; productive. Free. First to middle of July.

WINDSOR-Fruit large, liver colored, resembling the Elkhorn, ripening a few days after that variety; flesh remarkably firm, of fine quality. Tree hardy and prolific. Vigorous. Middle of July.
WOOD (Gov. Wood)-One of the best cherries; very large; light yellow marbled with red; juicy, rich and delicious. Tree healthy and great bearer. Hangs well on the tree. Vigorous. Last of June.

\section{DUKE AND MORELLO CHERRIES}

BRASSINGTON- $-W e$ believe this to be the most valuable cherry that can be obtained at the present time. Those who know of it have been hunting for the trees for a number of years but there were none. We now have a small supply. It is between a sweet and a sour cherry. Fruit is large, attractive, light red, juicy and fine. Bears in clusters and seldom fails to produce a big crop. Foliage has never been affected with shot hole fungus and hence remains on the tree till frost comes. An exceptionally fine, healthy strong growing tree.

EARIY RICHMOND-Medium size; dark red; melting, juicy, sprightly acid flavor. This is one of the most valuable and popular of the acid cherries, is unsurpassed for cooking purposes, and is exceedingly productive. Free. June.

IARGE MONTMONENCY - A large, red, acid cherry, larger than Early Richmond and fully ten days later. Very profitable. Last of June. MOREIID (English Morello)-Medium to large, blackish red; rich, acid, juicy and good; very productive. Moderate. August.

MAY DUIKE-Large, dark red, juicy and rich; an old, excellent variety; productive. Free. Mid. dle of June. 


\section{DELICIOUS PEACHES}

The Peach requires a well drained, moderately rich soil. Warm, sandy loam is considered the most ideal, but hundreds of the best orchards in the Ohio peach belt are grown on heavy clay soil.

We offer below a general list of varieties consisting of those suitable for either home use or commercial orchards. We offer a number of varieties of our own introduction which have stood the test for twenty-five or thirty years and have proved to be exceptionally hardy both in wood and bud. Among these extra hardy ones as Heidelburg, Days and Winstone. These varieties have frequently produced a good crop of fruit where everything had the fruit buds killed in the winter.

With Wilma and Salberta, in connection with Hale and Elberta we now offer a continuous Elberta season extending over a period of four or five weeks.

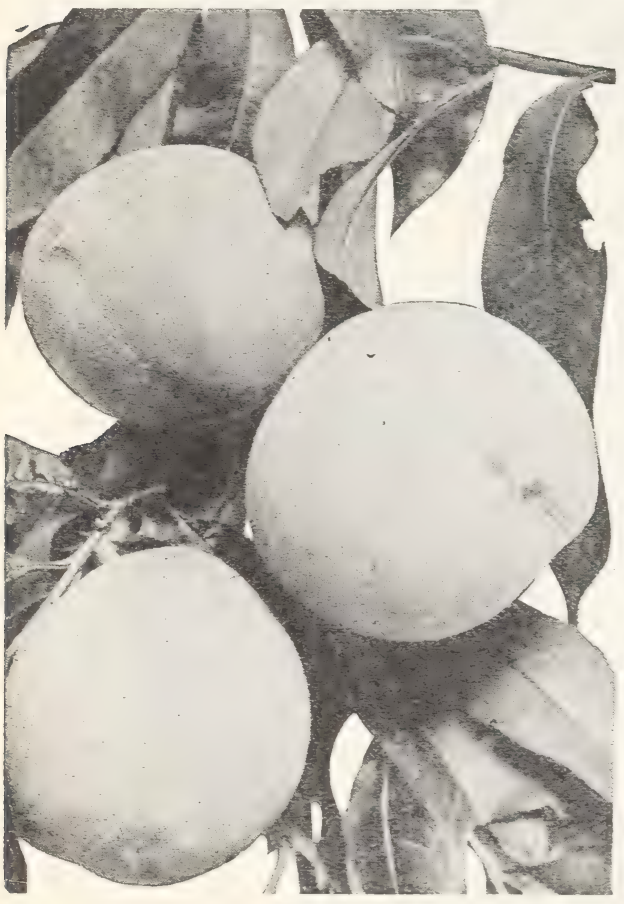

J. H. Hale

\section{LEADING PEACH VARIETIES}

AIEXANDER-Medium, greenish white, nearly covered with rich red; melting, juicy sort. July.

BANNER-A Canadian origination; one of the most profitable varieties ever produced. Fruit large, round and rery handsome. Tree hardy and an abundant bearer. Season October first.

CARMrN-Large, round, pale rellow skin with red cheek. Flesh white. The best quality of any of the real early varieties.

CHAMPION-A large handsome early variety creamy white with red cheek, sweet, rich and juicy. Hardy and productive. Follows Carman, August.

DAY - A heavy bearer of the rery finest peaches, and a very hardy tree; rellow freestone and colors up well on the tree. Originated in our orchard. One large peach grower says: "I would rather lose any other variety in my orchard than the Day's Nonpariel." Good size, but should be thinned for market growing. Ripens between Late Crawford and Smock.
DEWDY-It is a perfect freestone; flesh sellow of uniform color and texture to the pit. Hardy and productive. Tree is strong, symmetrical grower, and as near perfection as we can obtain in a single variety. Early August.

FARIY CRAWFORD-This rerT beautiful and best of yellow peaches is highly esteemed for mar. ket purposes. Fruit very large, oblong; skin yel low, sweet and excellent. Wonderfully produc. tive and hardy. Freestone. Last of August.

FARIY EIBERTA (Free)-Well named, being a. elear rellow with blush, finer grained and sweeter. Tree a strong grower. with a tendency to thin itself, carrying moderate loads of fruit.

ELBERTA-A seedling of Chinese Cling but entirely free. Large, rellow with red cheek, juicy and of high quality; flesh rellow and melting. A vers valuable sort. Ripens after Early Craw ford. Freestone.

GOID DROP-A rery roung and prolific bearer. Fruit medium size, rich golden rellow and of the finest quality. September.

HEIDEIBURG-The peach par-excellence for home use; rellow freestone of good size; delicious flavor and small pit; hardy tree and heavy bearer A splendid market rariety and stands shipping well. Ripens just after Early Crawford.

IREY-A rery fine large rellow freestone. well colored, ripening a little ahead of Elberta. Splen. did for local market. This is a Michigan variety, by some said to be identical with South Haven.

J. H. HALE-A comparatively new variety widely advertised and planted. Yery large, jellow and perfectly free. Said to ripen a few days ahead of Elberta, but in some localities the season is nearly the same. Succeeds best on a sandy loam soil.

KAIAMAZOO-A leading Michigan market sort: large, yellow. fine quality. Extra productive and profitable. September.

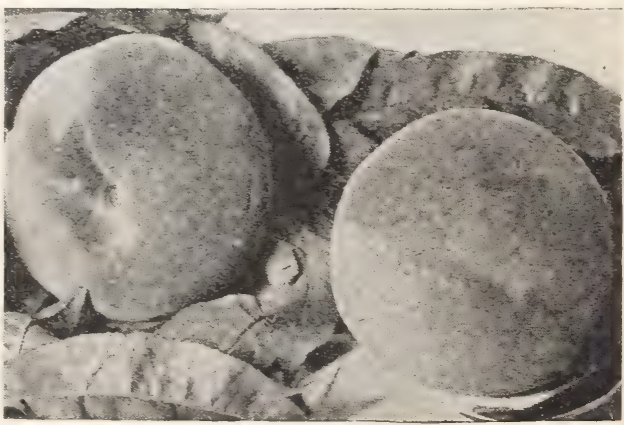

Elberta 
IATE CRAWFORD-Fruit of the largest size: skin yellow or greenish yellow, with dull red cheek; flesh yellow, productive. One of the finest late sorts. Freestone. Last of September.

IFMON CIING-Large, pale yellow, dark red cheek; hardy and productive. September.

IFMON FREE-Lemon color and shape; large and very large if thinned on the tree; immensely productive and a very hardy tree. Especially esteemed and sought for by canning factories as it holds together well when canned. Last of September.

NEW PROIIFIC-Large, attractive, firm; fles' yellow, fine flavor; hardy and productive. Sep tember.

ROCHFSTrR-A new sort of great worth. Fruits are large, sweet and juicy, with good ap pearance. Skin is yellow tinged with carmine. Keeps well and will stand shipment for long dis tances. Some of the trees bear in two years after planting. Hardy and prolific: good crops may be depended upon each year. Ripens about August.

SAIBERTA-Is a Salway-Elberta cross grown from an Elberta pit. A large yellow freestone of the finest quality ripening about two weeks after Elberta. This variety gives us a continuation of the Elberta season, and ripens at the same time as Smock, and has proved to be a heavy and sure bearer.

SAIWAY-Fruit large, roundish; deep yellow, with a rich marbled brownish red cheek; flesh yellow, juicy, rich and sugary. A good keeper and promising highly as a late showy market sort. Freestone. First of October. Too late in the north except near large bodies of water.

SMOCK (Beers)-An improved strain of Smock, being larger than the preceding but not generally considered as heavy a bearer.

STUMRP-Very large, roundish; skin white, with a bright red cheek; flesh white, juicy and good. Freestone. Last of September.

WIIMA-A late Elberta introduced by Mr. Rof. kar of Catawba Island, Ohio, a few years ago and now bearing in that section in many orchards. It is a large yellow freestone, highly colored, and

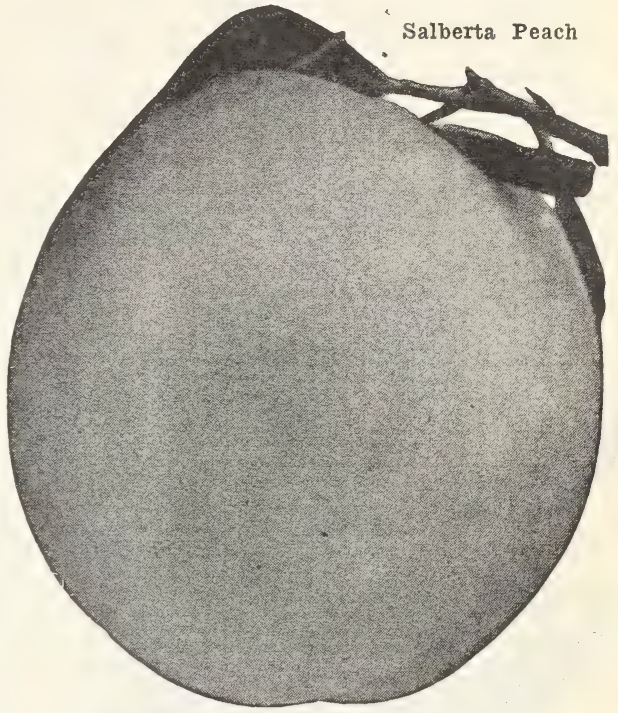

more prolific than its parent Elberta, and about a week later in ripening.

WINSTONF-A seedling of late Crawford which it resembles in every way, but tree is much har. dier. During the severe winter of 1904 we had a tree of Winstone and one of Late Crawford standing side by side in a small test orchard. The latter tree was killed completely, but the Winstone, a few feet away was uninjured and bore fruit the following season. This was also true of the Heidelburg and Day's Nonpariel while many of the old varieties such as Elberta, Crawford's Early and Late and others were entirely killed.

Also Crosby, Engel's Mammoth, Fitzgerald, Mayflower, Old Mixon, Slappey and others.

\section{QUINCES--For Flavor}

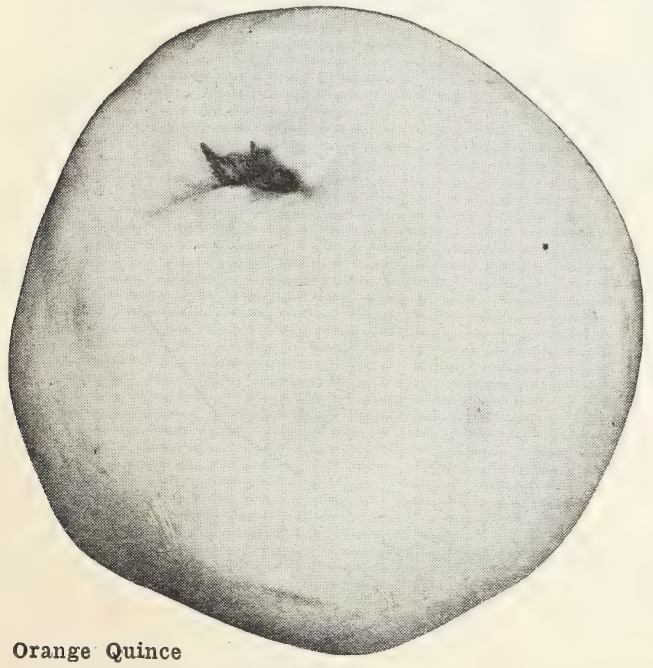

In Quinces we have a very desirable fruit. It is used a great deal for preserves and canning especially with other fruits. A small part of quince will impart the quince flavor to three or four times as many apples.

BOUGEAT-Tree a remarkably strong grower. Fruit of large size, round; rich golden color smooth; very tender when cooked.

CHAMPION-A prolific and constant bearer, fruit averaging larger than the Orange, quality equally fine, and a long keeper; bears extremely young. Ripens late.

MEDCH-The fruit is large, lively orange yellow, of great beauty and delightful fragrance; its cooking qualities are unsurpassed.

ORANGE (Apple)-Fruit large, round, with a short neck; color bright yellow; flesh firm and tough until cooked, when it becomes tender, juicy and of excellent flavor. We recommend the Orange as the best all around variety to plant. 


\section{ALWAYS ROOM FOR GRAPES}

The vines come quickly into bearing, yielding fruit usually the second year after planting, requires but little space, and when properly trained, is an ornament to the yard, garden or vineyard.

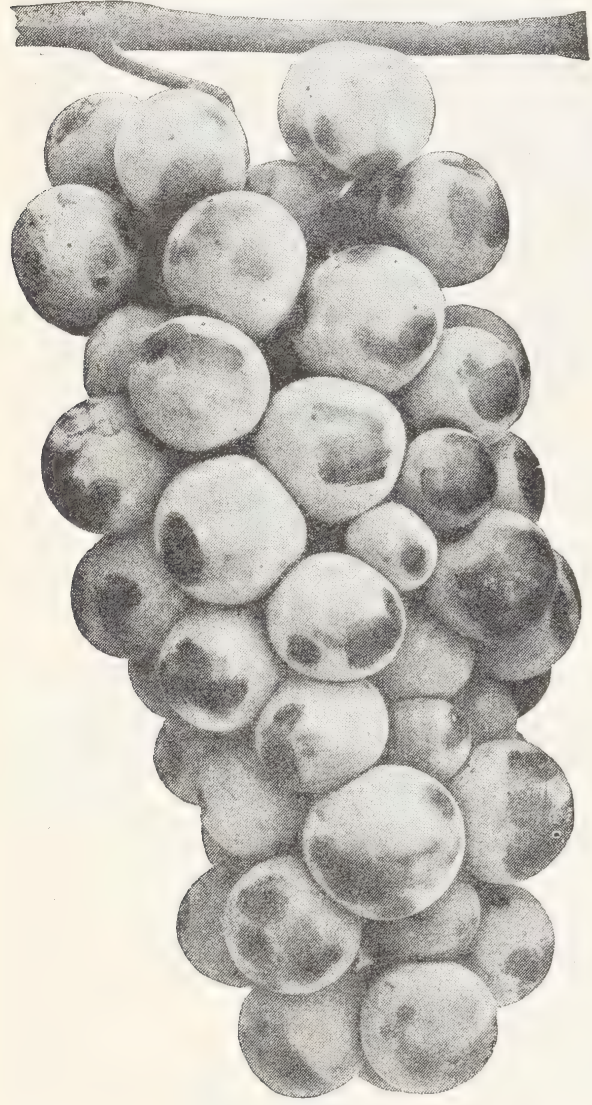

Brighton Grapes

BRIGHTON-Bunches large, berries of medim size, dark red; flesh sweet, tender and of the highest quality. Ripens one week earlier than Delaware. First of September.

CAMPBEII'S EARIY-Clusters large atd handsome; berries large; nearly round, black, with light purple bloom; flesh tender; quality rich, sweet, slightly vinous; strong vigorous grow. er, with healthy foliage; ripens very early; ber. ries do not drop easily from clusters, and the fruit keeps a long time in perfection.

CATAWBA-Bunches and berries large, of coppery red color, becoming purplish when well ripened. Last of September.

CONCORD-A popular variety, universally sweet. Bunch large, nearly black with bloom: healthy, vigorous and productive; flesh juicy and early. September.

DEIAWARE-Still holds its own as one of the finest grapes. Bunches small, compact, shouldered; skin thin, light red; flesh very juicy, without any hard pulp, with an exceedingly sweet, spicy and delicious flavor. Vines moderately vigorous, very hardy and productive. September.
DIAMOND-White; bunch large. Flesh ten. der, juicy with but little pulp. Vine a good grower with thick, healthy foliage; hardy and productive. September.

MOORE'S EARIY-A seedling of Concord, combining the vigor, health and productiveness of Concord, and ten days earlier. In quality hardly to be distinguished from Concord. Bunch large. berries very large, black. August.

NIAGARA-Bunch medium to large, compact. Berry large, roundish, uniform, of pale greenish color; flesh slightly pulpy, tender, sweet. Vine remarkably vigorous, healthy and productive. September.

POCKIINGTON-It is a seedling from Concord; fruit a light golden yellow, clear, juicy and sweet to the center, with little or no pulp; bunches very large. First of September.

WORDEN-Bunches large, handsome, double shouldered; berries large, sweet. Being ten days earlier than Concord, it ripens well in cold localities; vine very thrifty and vigorous, perfectly hardy and a good bearer. Middle of September.

WYOMING-An early, light red grape with iron clad vine and foliage; always yielding enormous crops. It ripens with Delaware, which it resembles in appearance, although larger in bunch and berry.

Indiana, Nov., 11, 1927.

The trees all came through in the very best of order. I never received finer stock. Thanks for the extras.

WM. H. REPLOGLE.

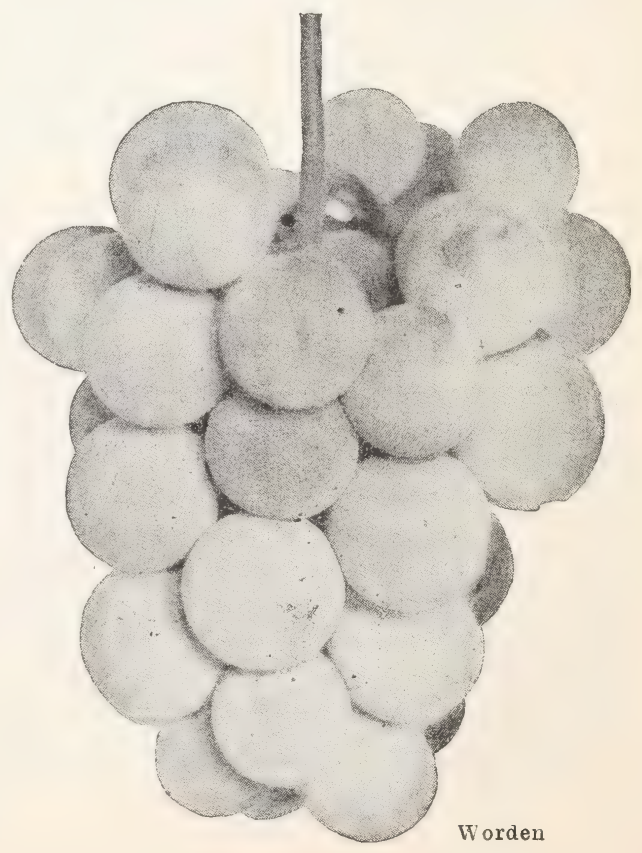




\section{STRAWBERRIES}

To insure best results Strawberries should be freshly dug, packed by themselves and shipped by express. We never dig them till we are ready to ship and consequently have usually had good success even when we sent them by freight along with other stock. They should always be attended to and planted at once on receipt of goods. We grow eighteen or twenty of the best varieties and our list is changing most every year. Varieties with imperfect or pistillate flowers are marked "P", those with perfect or staminate flowers are marked "S". Where pistillate varieties are planted, every third or fourth row should be some staminate variety that blossoms at the same time, in order to produce plenty of pollen to fertilize the imperfect flowers of the pistillate sorts.

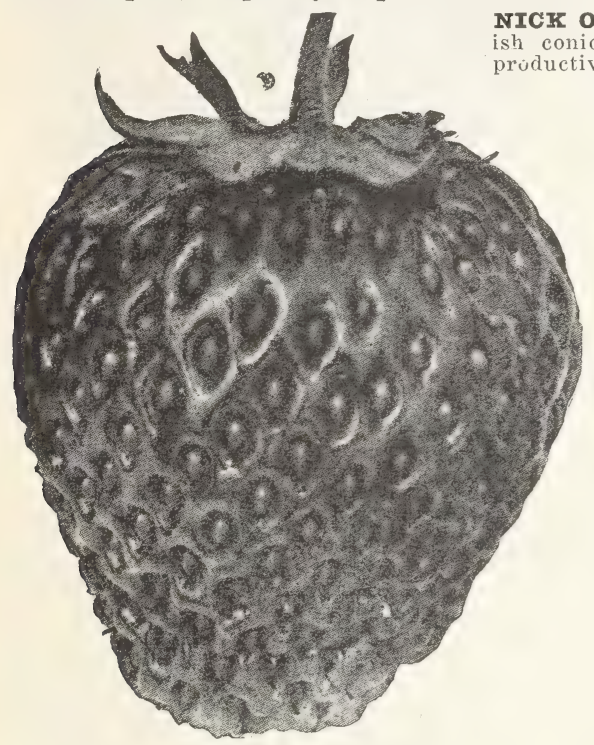

Cooper Strawberry

CHESAPEAKE (S)-The extra fine strawbery said to be the "best morsel man ever put into his mouth." Fruit dark red, large and very firm with the real strawberry flavor. A strong growing plant with heavy root system. COOPFR (S) - A remarkable new variety taking a lead in the large berried class. Fruit uniformly large, very sweet and ripening evenly. Begin to ripen early and continues over a long season. Plants very strong and heavily rooted. You should not fail to plant some of these.

DUNIAP (S) - A well-tested, wonderfully productive variety, one of the safe sorts to plant anywhere and sure to take a high place among the prominent standard sorts. Plant resembles Warfield, rampant runner, should be restricted in its production of plants. Fully equal to Crescent and Warfield in its ability to succeed under all circumstances. Fruit good size, regular form, beautiful bright red, glossy, firm, splendid keeper and shipper, excellent quality; one of the best for canning; ripens early and continues a long time. It promises to stand at the head in its wonderful ability to ripen a good crop under almost any condition of drought or neglect.

GANDY (S) - Large, late, firm, bright crimson; uniform in size and shape. Vigorous and productive; one of the best late varieties.

GIBSON (S)-Large, late, firm, bright crimson; become a strong rival to Dunlap.

GIFN IMARY-Berries large to very large, often flattened, bright deep red on surface, light red to center, sweet, rich, good flavor. Season medium to late. One of the most productive and holds its size to end of season. Plant very vigorous. One of best for home use and near-by markets.

PREMIER-In this section the largest, most productive and best well tested early variety. Fruit highly colored, firm, a splendid shipper, of aperb quality. Strong, clean foliage, plant grows spreads over its load of fruit protecting it

SAMPIE-A strong plant that succeeds well on nearly all soils and yields astonishing crops of uniformly large, fine berries, pointed conical, rich scarlet, firm and of fair quality. A money-maker for the marketman and destined to become one of the standard sorts. It is being planted in imquantities.

RIIID (P) - The great market berry of Famous for its flaming color, great firmness and unsurpassed flavor. Many hotels and restaurants in the great cities advertise Warfields strongly as fame for flavor and lusciousness. As a canning per, comes in early and is enormously productive. WM. BFIT-Berries very large, conical, bright red, of good flavor. The plant is strong, healthy and very fruitful. Season medium to late.

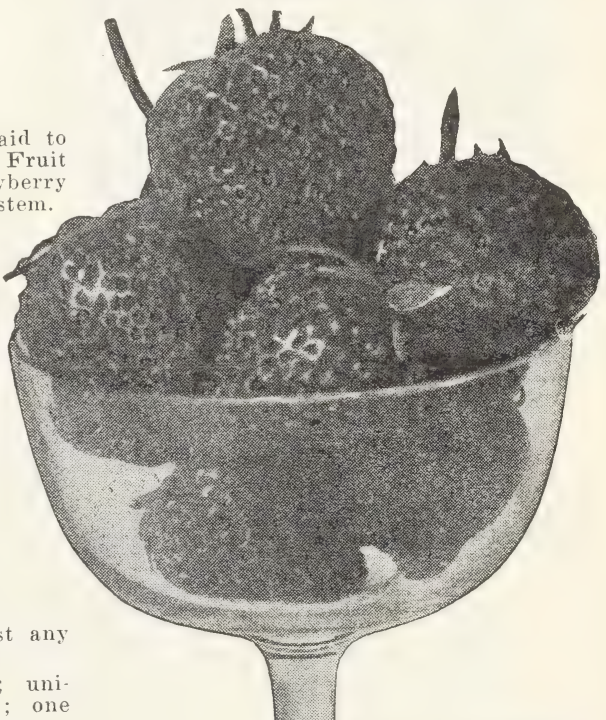

Warfield Strawberries

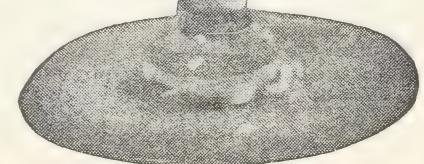




\section{EVERBEARING MASTODON STRAW- BERRIES}

In past years we have tested out many varieties of these everbearers. Most of them have been worthless. others have been fairly successful but it remained for the new variety, the Mastodon, to prove to us that it was so far ahead of all the other kinds of everbearing strawberries as to be really worth while. We were skeptical at first but to say that it has so far surpossed our expectations and produced such wonderful results as to surprise us would be to put it mildly.

We have had an abundance of fine luscious berries from a small bed of them ever since the middle of Tuly. For weeks we picked them every day obtaining several quarts to a picking. At this writing, in November, although the ground is covered with snow and the berries have been frozen, there are thousands of large sized berries in all stages of development together with blossoms, now turned black with freezing.

The plant is an extra large robust one with the largest root system that we ever saw on any variety. The berries are large and average large all tbrough the season. They are of the best possible flavor. Everyone who has tasted them this summer has pronounced them extra fine quality. The plants throw out a surprising number of fruit stems. If the first crop of blossoms is picked off of the plants on planting in the spring they will produce all the balance of the season. The following season they will produce a bigger crop of bigger berries than any other variety of spring berries that there is.

This variety has given such wonderful results

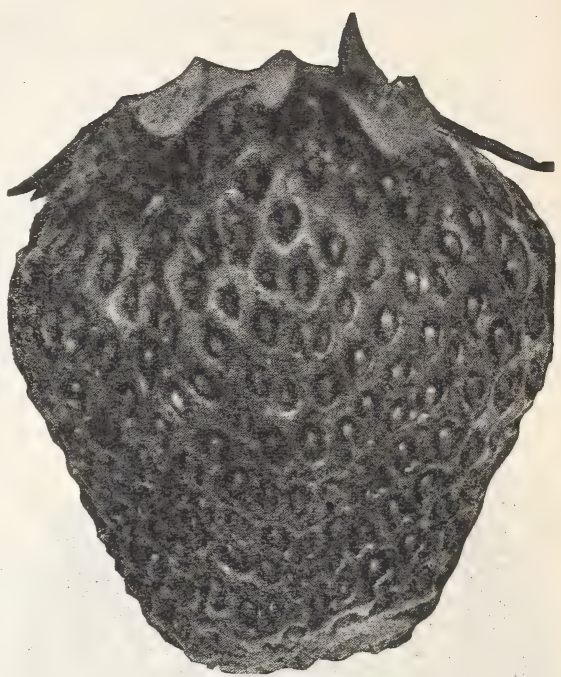

this year and has been the source of amazement to hundreds who have seen it in bearing that we feel we can hardly recommend it too heavily.

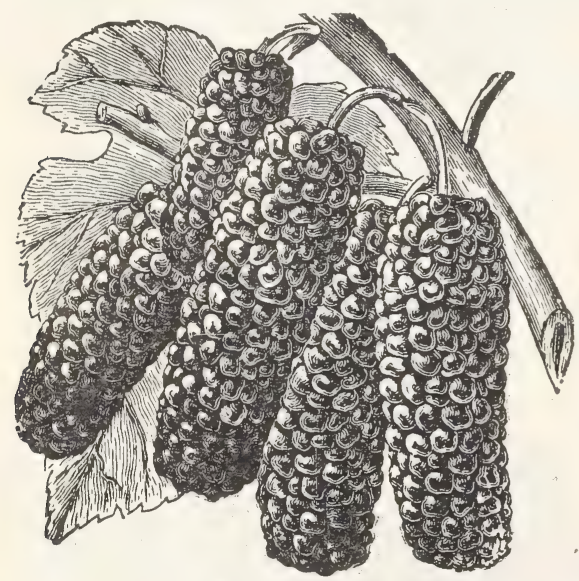

\section{MULBERRIES}

The Mulberry is valuable as an ornamental shade tree and the fruit is quite popular in many sections. It is especially valuable in poultry parks.

DOWNING AND NEW AMERICAN-Are by long odds the two best varieties of Mulberries to plant for fruiting purposes. Both are very large, fine berries, black when fully ripe and continue to mature fruit for six to eight weeks in midsum. mer. The Downing is too tender a tree for our northern winters and we therefore recommend the New American which is much more hardy, and just as good in every way.

\section{RHUBARB}

MYATT-Early, very large, tender and delicately flavored; requires less sugar than other sorts.

\section{ASPARAGUS}

CONOVFR-Very large size and of excellent quality; has superseded the old varieties.

\section{GOOSEBERRIES}

Gooseberries sould be planted in good, rich soil and well manured once a year. Pick regularly, thoroughly cutting out all dead wood and surplus branches. Plant in rows 4 feet to 6 feet apart in row. It is well to mulch heavily in the fall. Plants are hardy, rugged and easily grown.

DOWNING-Fruit larger than Houghton, roundish; light green, with distinct veins; skin smooth; flesh rather soft; juicy and very good. Vigorous and productive. The most popular variety for market growing.

HOUGHTON-A medium sized American variety, which bears abundant and regular crops and never mildews; fruit smooth; red, tender and very good; valuable.

JosאIYN (Red Jacket)-An American seedling of large size; smooth, prolific and hardy, of best quality. Has been well tested over a wide extent of territory by the side of all the leading varieties, and so far the freest from mildew, both in leaf and fruit of them all. A wonderful cropper, with bright, clean

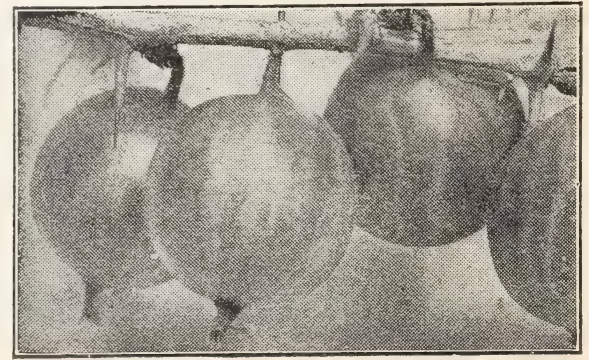
healthy foliage. 


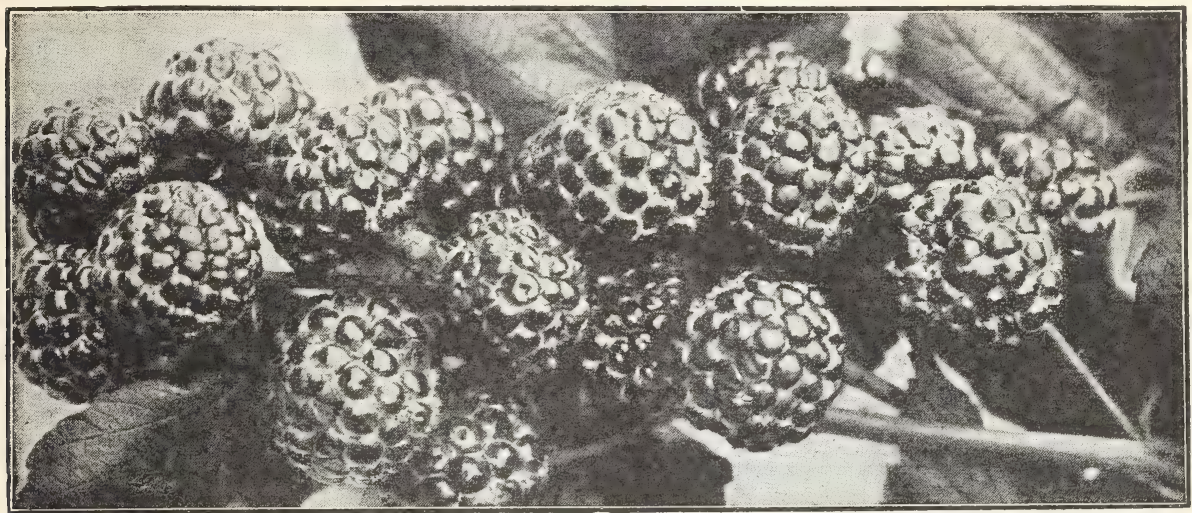

\section{RASPBERRIES}

Raspberries are one of the most delicious and popular fruits grown, are easily cultivated and require little care. Cut out old and weak roots each year. Plant in good soil in hills about four feet apart. With a little care and attention they will produce large crops of berries. In large plantings it is advisable to plant them thickly the same as hedge row.

\section{RED AND PURPLE VARIETIES}

CorUmbian (Purple Cap) - The Columbian is a variety of the Shaffer type; of remarkable vigor and productiveness. It is very hardy and a rank, thrifty grower; propagates from the tips, same as black caps. Fruit very large and grows abundantly; very rich flavor, tart, a splendid berry for jelly, pies and for canning.

ST. RFGIS-The so-called everbearing. It does produce some berries throughout the summer, and in the spring is an excellent producer. Quality very good.

HAYMAKER - A purple cap, not so dark as Columbian or Shaffer, and larger and firmer than either of those varieties; never crumbles, and stands up well in shipping. Sample crates have been shipped to distant points with entire satisfaction. It is a berry to grow for either home use or market.

IATHAM-A new variety introduced in Minnesota. Perfectly hardy in that section. We believe this to be the very best red variety ever introduced. It is large size, very fine quality and very

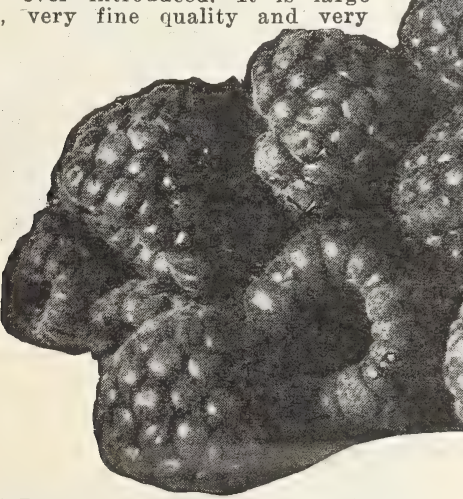

CUTHBRRT-Leading late variety, all over the country. A very rank grower. Very productive. Fruit large and of good quality. If you want a good all round late red raspberry, plant the Cuthbert. productive. The Connecticut Agricultural College reports a yield of 5430 quarts per acre on 3-year field against 3600 quarts per acre for Herbert and Cuthbert. It is firm and holds out in size throughout the season. While not introduced as an everbearer yet it usually bears some fruit all through the season.

Our plants are obtained direct from the introducer in Minnesota and are disease free.

\section{BLACK CAPS}

CUMBERIAND-The largest of all the black caps; coal black berries; very firm and quality of the very best; excellent shipper. Bush a strong grower, stocky canes and unusually prolific. Mid-season.

GREGG-One of the most valuable varieties of the black cap family; fruit larger than Mammoth Cluster, but not quite so good in quality; ripens some days later; hardy, a vigorous grower and great yielder.

NEW IOGAN-Here is the berry we have been seeking for years. As large as Gregg, earlier than Cumberland, and more productive than either. Resists drought perfectly and holds up well during the entire season, being far superior to Cumberland in that respect. More hardy in winter and less susceptible to disease than Cumberland. $\mathbf{H}$ a $\mathrm{s}$ been thoroughly tested in this vicinity for a number of years and has held up to expectations in every case. 


\section{BLACKBERRIES}

We grow our blackberry plants from root-cuttings, and in this way get plants with plenty of fibrous roots, which make sure the growing of the plant. In fruiting patches of blackberries there will spring up many plants from the root, and these are the plants that are usually dug up and sent out to the trade. They have but few, if any fibrous roots, and are much more apt to die when planted, and will not make the growth after planting that the plants will when grown from root-cuttings.

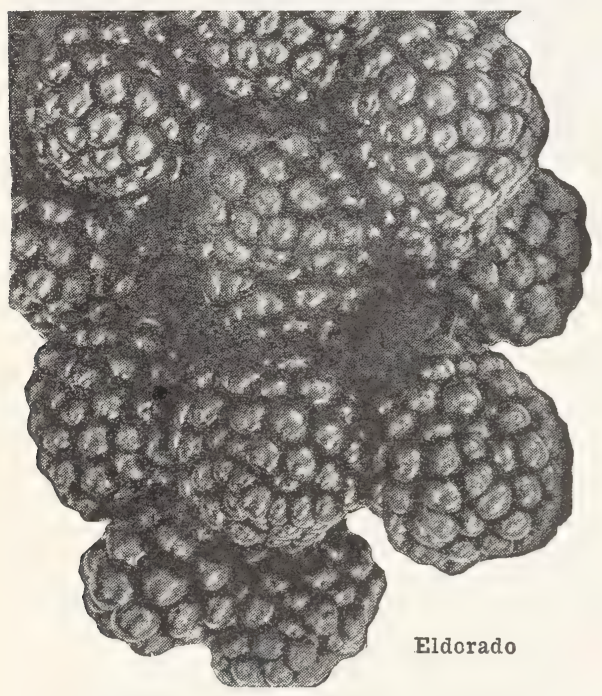

BIOWFR-Originated in the celebrated small fruit belt of Chautauqua County, N. Y., where it has been thoroughly tested for several seasons. Claimed to be the hardiest, most productive, the finest quality and to bring on the market the highest price of all blackberries." Has produced 2694 berries on one bush, 2720 quarts on onethird acre. Large size, jet black, good shipper, best quality, unexcelled productiveness are the main characteristics of this splendid new sort.

FIDORADO-A valuable new variety; fruit medium size, jet black, melting, sweet and rich, plant hardy and very productive.

SNYDER-Extremely hardy, enormously productive, medium size, no hard, sour core, half as many thorns as Lawton or Kittatinny, and they are nearly straight and short; exceedingly productive.

TAYIOR-One of the largest blackberries grown. Very productive, and as hardy as the Snyder.

IUCRETIA DEWBFRRY-The best of the blackberry family. Berries are far larger and better than any blackberry; of unequalled excellence; sweet and luscious throughout, of brightest glossy black color. Its trailing habit renders it less liable to winter kill. Propagates from the tips. Plant in rows six feet apart and plants three feet apart in the row.

\section{GURRANTS ARE HEALTHY}

The currant is one of the most reliable of small fruits. They mature just before raspberries and can be used either raw or cooked. Being hardy, they do not winter kill, are easy of cultivation and require little care. They can be grown in any good garden soil. The market is never over-supplied. Prune out dead wood, and mulch heavily. If currant worms appear spray with arsenate of lead.

BIACK NAPIES-Very large, black; rich, tender and excellent for jellies and wine; very productive.

CHERRY - Very large deep red; rather acid; bunches short, plants erect, vigorous and very productive.

FAY-Color deep red; great bearer; stems longer than Cherry, and berries hold their size to end of stem better. Quality first class; not quite so acid as Cherry; the best of all the red currants.

PERFECTION (Red)-This truly wonderful new currant has both large and extra good quality. Perfection healthy, a vigorous grower, and in fact an extra fine red currant in every way. Widely advertised all over the country.

WHITE GRAPE-Very large, yellowish white. The finest of the white sorts. Very distinct from White Dutch, having a low spreading habit and dark green foliage. Very productive.

WIIDFR-Very light; bright red and attractive; a splendid market sort; not so acid as most. Bush very productive; large bunches; ripens rather

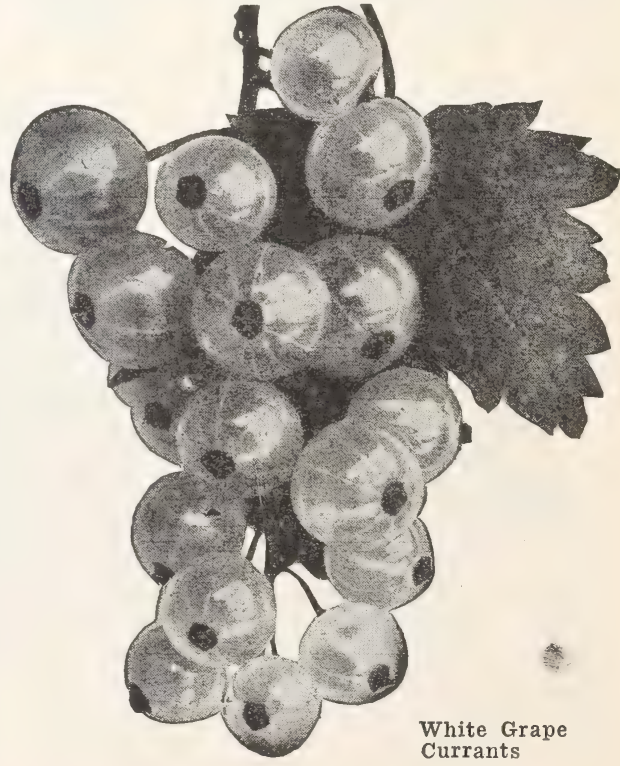
early; fruit keeps well. 


\section{DECIDUOUS TREES}

The planting of well selected trees is a duty each landowner owes to himself and posterity, and a duty which should not be delayed, the sooner planted the longer both yourself and the public may enjoy them. Trees and shrubs add to the value of your property.

\section{NUT TREES}

CARSTNUT (American Sweet)-A valuable native tree, useful and ornamental; timber is very durable, and possesses a fine grain for oil finish. Nuts sweet, of delicate flavor, and are a valuable article of commerce.

WAINUT (Japan Sieboldi) - Perfectly hardy here, rapid grow. er, handsome form, immense leaves; bears young and abundantly one of the finest ornamental trees. Nuts produced in clusters; resembles Butternut in shape and quality.

Black-Our native variety, valuable for its fruit and also for timber. Also white or Butternut and English.

\section{ORNAMENTAL TREES}

ARALIA Spinosa-(Hercules Club) (Devil's Walking Stick) A showy native tree with branched leaf stems two to three feet long. Used for tropical effect as it resembles a palm. Body covered with small spines. Very unique. Huge clusters of fine white flowers in July.

\section{BIRCH}

CUT-IEA VED WEEPING (Pendula Laciniata)-This tree is indeed a picture of delicacy and grace. It presents a combination of attractive characteristics of which no other variety can boast. Leaves finely cut, branches drooping, silvery white CATAIPA BUNGEI (Umbrella Catalpa). Grafted on stems 4 to 8 feet high, it makes an umbrella-shaped to pwithout prun. ing. Perfectly hardy, and flourishes in all soils and climates Leaves large, glossy, heart-shaped, deep green, lying like shing. les on a roof; always maling a symmetrical head. Usually set in pairs on opposite sides of a walk, entrance, etc.

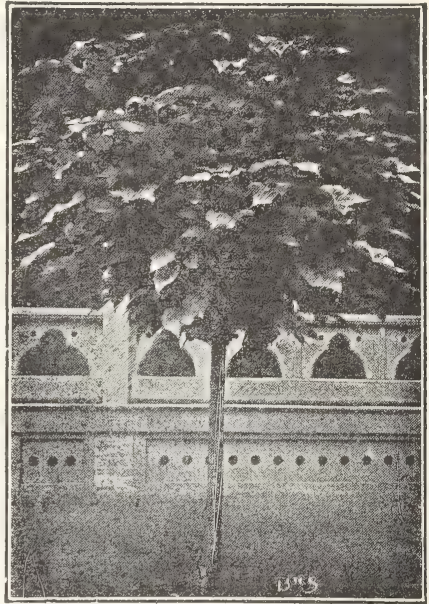

Catalpa

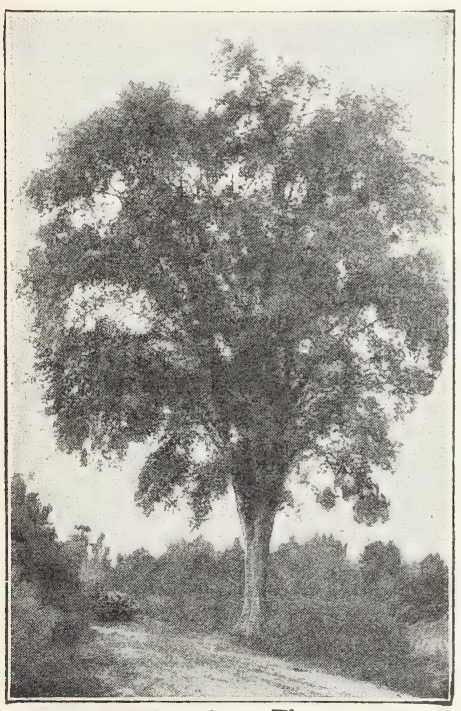

American Elm

SPECIOSA-Valuable for timber, fence posts, railroad ties, etc., on account of rapid growth and durability. Large heartshaped, downy leaves, and compound panicles of white flowers, tinged with violet and dotted with purple and yellow.

\section{CHERRIES}

JAPANESE FLOWERING, DOUBIE WHITE AND PINK - Very fine and rare. And being largely planted now (days).

\section{CRABS FLOWERING}

ATROSANGUINEA-Makes a beautiful contrast to the other varieties by reason of its darker red flowers. The buds are deep purplish red, and the entire flower tinged purplish.

BECHTEI'S DOUBLE FLOWERED-One of the most beautiful of the many fine varieties of flowering crabs. Tree of medium size, covered in early spring with large, beautiful, double fragrant flowers of a delicate pink color. From a distance the flowers have the appearance of small roses. A great ac quisition, and certain to become very popular. Blooms when quite young.

SCFEIDECKERI (Double-flowering Crab)-Flowers double, bright rose, of great substance and durability. Splendid for cut flowers. Crabs are now

very popular and beautiful.

\section{CORNUS OR DOGWOOD}

C OR N U S FUORIDA (White-flowering Dogwood) -B. American variety of irregular habit with spread. ing open top, growing about $25 \mathrm{ft}$. high. The flowers are white, produced in May, followed by scarlet berries and gorgeous Autumnal coloring of the leaves.

C. VAR RUBRA (Red-flowering Dogwood)-This merits all the favor which has been shown it by the public. The flowers are like Cornus florida, except that they are a deep rose-color, freely produced. A fit companion to the white form.

\section{ELM}

AMFRICAN-A very large, rapid growing native tree with broad, spreading and drooping head. Very valuable for shade or timber. Hardy and succeeds well on most any soil, even adapted to low, wet black soils.

See Back Cover Page for Rare Varieties and Novelties.

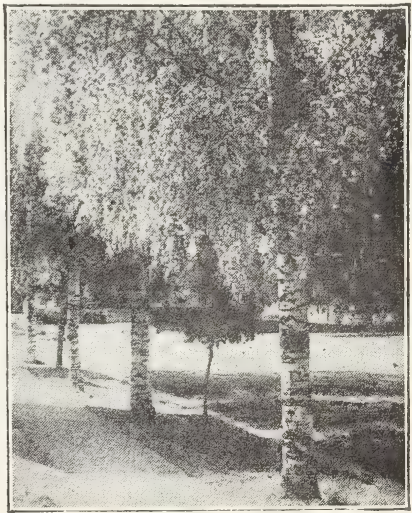

Cut Leaf Weeping Birch 


\section{HORSE CHESTNUT}

WIITE FIOWFRING-Decidedly the finest variety of this family. Makes a beautiful tree of regular outline. Exceedingly hardy and free from all diseases. Covered in May with magnificent white flowers tinged with red. Forty to fifty feet when fully grown.

\section{KOELREUTERIA-VARNISH TREE} KOFIRFUTERA PANICUIATA-If only for its mass of orange-yellow flowers, which ir July cover the tree, this should be grown. It is a small-growing tree from China, with large pin. nate leaves. An unusually good lawn tree.

\section{LINDEN}

AMIRICAN-A stately tree, growing 60 to 80 feet tall, with large, shining cordate leaves. Valu. able for its beautiful white wood. Its flowers ap. pear in July.

EUROPEAN-Largely used for street and orna. mental planting, developing into beautiful speci. mens.

\section{LARIX-LARCH}

IARIX FUROPAEA (European Larch)-Compact in growth, with light green foliage and drooping habit. Valuable as a timber tree. Resembles an Evergreen in summer.

\section{LIQUIDAMBAR}

IIQUIDAMBAR STYRACIFIUA (Swe e Gum). Its star-shaped leaves, glossy and green in Summer, takes on in the Fall the most intense shades of purple, orange and crimson, and for this Autumn aspect alone, it should be grown. MAGINOIIA - See back cover page.

\section{MAPLE}

The vigorous growth, fine form, hardiness, freedom from disease, and adaptability to all soils, renders the maple one of the best of trees for the purpose of shade. It has few equals for the street or park.

ASH IFAVED-A hardy native sort. Ash-like foliage, spreading head. Rapid growth. Hardy. GINNAIA (Siberian Maple)-More like a large shrub, with three-lobed leaves and flowers in long panicles. Foliage turns bright red in autumn. Sometimes used as a substitute for the Japanese Maple.

JAPAN-See back cover page.

NORWAY (Platanoides) - Large, compact habit, and broad, deep, green, shining foliage. A stout, vigorous grower. One of the best for the street or park. Forty to fifty feet when grown.

SCFWEDIERI-A beautiful variety of Purple Leaf Norway and crimson color which changes to purplish green on the older leaves.

SIIVER IRA VED OR WHITE-Foliage bright green above and silvery underneath. An exceedingly rapid grower, and makes a large tree.

SUGAR OR ROCK-The well known native var. iety. Valuable for the street or park. Fifty to sixty feet when fully grown.

WIER'S CUT IEAVED-Grows rapidly, and the shoots are so slender and drooping that it has a decidedly graceful appearance. The leaves are deeply and delicately cut. A large tree if undisturbed, but will stand severe pruning, and so may be easily adapted to small places.

\section{MOUNTAIN ASH}

EUROPEAN-A more desirable variety than the American, being of finer growth and form. It blossoms during the early spring, after which the bright scarlet berries are formed in clusters. Twenty to thirty-five feet when fully grown.

\section{MULBERRY}

TEA'S WIEPING-Perfectly hardy, forming a natural umbrella-shaped top or head; foliage handsome; a fine ornamental for the lawn.
OAK

PIN-Broadly pyramidal in habit, described as half-weeping when old, because its lower branches touch the ground. It grows comparatively fast up to 60 to 80 feet. The leaves are deep green, glossy, and finely divided; orange-scarlet in fall. One of the richest and finest boulevard trees.

\section{POPLARS}

Poplars are desirable where rapid growing varieties are wanted, and they are also very distinct and striking.

CAROLINA - Of compact habit. A very rapid grower. A desirable tree for the seashore and for our large cities, where escaping gas kills most shade trees. Fifty to sixty feet.

IOMBARDY-From Italy. Remarkable for its erect, rapid growth, and tall, spiry form. Of great value for planting with other trees to break the average height and form. Fifty to seventy. five feet.

SIMONI-Medium height, bushy and rapid growing. Foliage small, oval, tapering at stem. Very dark lustrous green. Bark stained with red.

\section{PRUNUS-PLUM}

OTfELIO - Is a handsome lawn tree, with its brilliant reddish purple foliage, bright clusters of white flowers in early spring, and profusion of deep crimson fruit ripening the very earliest of all Plums.

PISSARDI (Purple-leaved Plum)-Either as a shrub or low tree, the bright purple foliage throughout the season gives this variety unique value for planting singly or in groups.

NEWPORT-A new variety from the northwest, said to be the best of the red or purple leaf varieties.

TRILOBA FL.-PI. (Double-flowering Plum)A charming shrub or small tree, 3 to 5 feet high, of spreading, vigorous growth. Very early in spring before its leaves appear, the whole tree is decked in a fleecy cloud of pink blossoms.

\section{RED BUD-JUDAS TREE}

Before the foliage appears, the stems are clothed with a profusion of reddish-purple flowers. quite unique in color and appearance. The leaves are heart-shaped with a glossy surface.

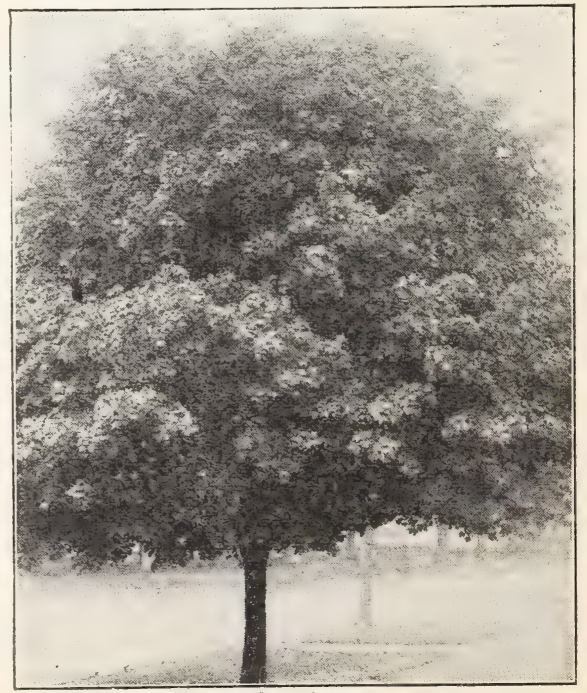

Schwedleri Maple 


\section{SYCAMORE-EUROPEAN}

As an ornamental tree for large grounds, or as a shade tree for street planting, this has no superior. It is a rapid grower, attains a large size, and presents a striking combination of majesty and gracefulness. The foliage is heavy and not subject to ravages of insects.

\section{THORN-DOUBLE FLOWERING OR HAWTHORN}

PAUI'S DOUBIF SCARIFT THORN-Of quick growth, showy, and perhaps the best sort. The large, perfectly double flowers in May are a rich, glowing crimson.

DOUBIE PINI HAWTHORN-Pretty, rose colored, double blooms in May.

Also double white Hawthorn.

\section{TULIP TREE}

Among the largest of our native trees, forming broad, spreading specimens. Leaves glossy and fiddle-shaped. The flowers resemble Tulips, and are large and greenish-yellow, blotched with orange, appearing in June.

\section{WILLOW}

BABYLONICA (Babylonian Willow) - The well known large Weeping Willow. Most valuable as a single specimen to contrast with upright trees. DIsCoIOR (Pussy Willow)-A strong, erect grower, producing the large purplish catkins in very early spring. In much demand for "spray" bouquets. Grows anywhere.

WISCONSIN WEEPING-A variety resembling the Babylonian Willow, except that it is more hardy.

\section{ORNAMENTAL SHRUBS}

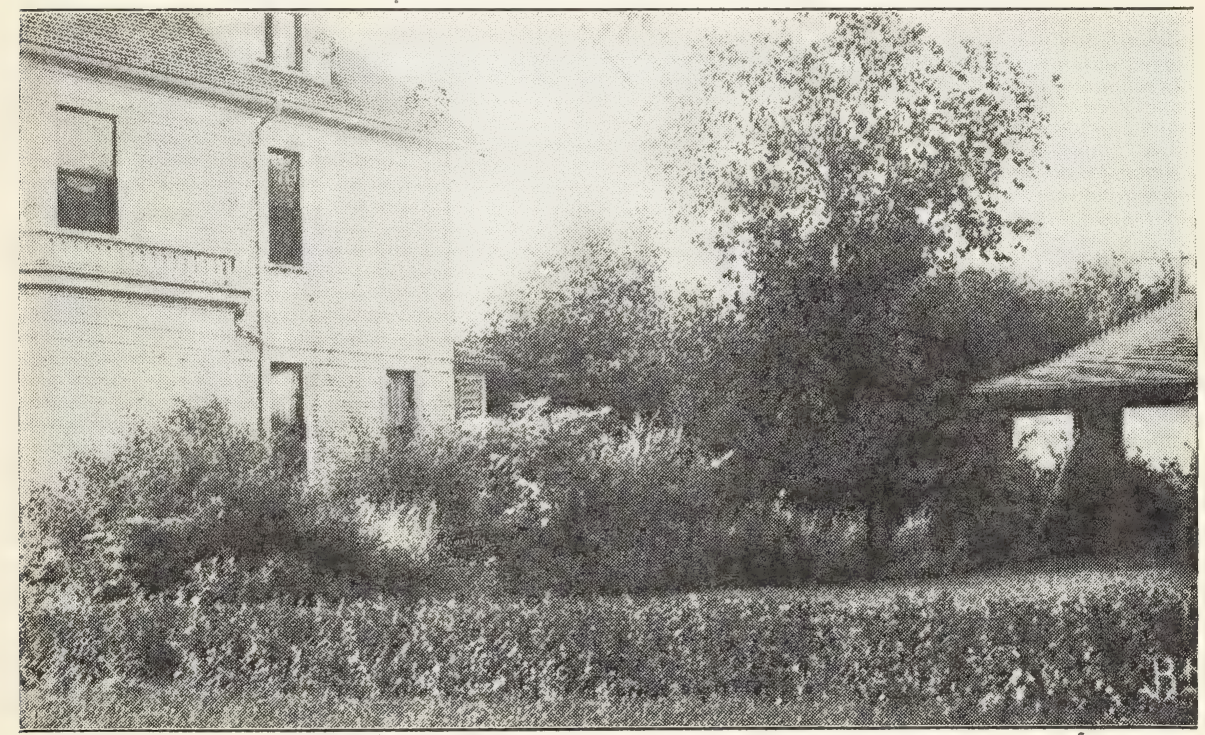

In Shrubs we pursue the same policy as we do in fruits, viz: to offer only those which we have known to succeed and those which we consider as hardy in this latitude. We test many new ones each year as they are offered and if they meet our requirements in a shrub we adopt it permanently and offer it for sale. We now have a business in landscape work that requires thousands of shrubs each year. We will prepare planting plans and estimates when desired. Our Shrubs will be found especially well rooted as our soil produces an abundance of fibrous roots.

\section{ALMOND}

FIN K FLOWERING ALMOND-Rose-pink April. Very attractive shrub. The plants are us. ually thickly studded with double pink flowers of medium size from base to tip of branch.

\section{ALTHEA OR ROSE OF SHARON}

The Altheas have a well-deserved popularity. They are free growers, and not particular as to soil. They bloom in August and September, when but few other sorts are in bloom. They attain a height of six to ten feet. We can furn. ish double or single in a variety of colors, as red, white, pink, purple and variegated.

AMORPHA FRUTICOSA-Grows 6 to 10 feet high in large spreading bush form, with bright green leaves in pinnate arrangement; flowers deep violet blue, in June.
ARAIIA PFNTAPHYIIA (Acanthropanax) Long, slender, gracefully arching branches and bright green, compound foliage. Makes a small tree in time, especially attractive on rocky slopes. Greenish white flowers in long umbels.

\section{AZALEA-THE AZALEAS}

These are, without exception, the most showy of flowering shrubs. Dwarf in habit, they asso ciate well with other shrubs, or can be grouped in masses. They prefer deep leaf-mould soil or peat, which will not dry out in summer.

A. MOIIIS-Dwarf habit and larger flowers than the Ghent. Resembles Rhododendron; goor foliage; flowers in all shades of red, white, yellow and orange; perfectly hardy, thriving in sunny positions anywhere. 


\section{BARBERRY}

THUNEFRGII-A most interesting and valu. able shrub. Habit dwarf and spreading but delicate and shapely. Blooms in May, are white and a profusion of scaret berries. Autumn foliage brilliant.

RED-IEA VED- (New). An outstanding novelty that is of great value. Similar in every re spect to the green leaved Japanese Barberry, but color of the foliage is a rich, bronzy red and retains its rich hue all summer, and in fall changes to shades of rich orange, scarlet and red, more brilliant than the ordinary barberry. To keep its brilliant red color all summer it should be plant ed in full exposure to the sun.

\section{BUDDLEIA VEITCHIANA}

BUTTERIIY BUSH OR SUMMER IIIACOne of the most desirable summer flowering shrublike plants, beginning to lloom in July. The flowers are of a pleasing shade of violet mauve, and are borne in dense cylindrical spikes, which under liberal cultivation, are from 12 to 15 inches in length by 3 inches in diameter; it succeeds everywhere and flowers free'y the first season planted, and is always admired. Tops die back to the ground in winter.

\section{CALYCANTHUS OR SWEET SCENTED SHRUB}

Blooms in June, and at intervels through the summer. Flowers of a rare chocolate color; rich foliage. The wood and blossoms have a peculiarly agreeable flavor. Three to five feet high when fully grown.

\section{CARAGANA-SIBERIAN PEA SHRUB}

ARBORESCENS-Growing 10 to 12 feet tal in good soil, it makes a handsome show in late spring with its compound, bright green foliage and numerous small clusters of bright yellow flowers. It is perfectly hardy and is valuable either for mass or individual planting.

CIETHRA AINIForIA (Sweet Pepper Bush) A handsome little shrub, delightfully fragrant in August and September when covered with long, showy wands of creamy white flowers. It is valuable for the front of the border, as it grows only 3 to 5 feet tall, and on account of its pleasing scent, is very popular in the little shrub groups so often planted in the corners made by the porch steps.

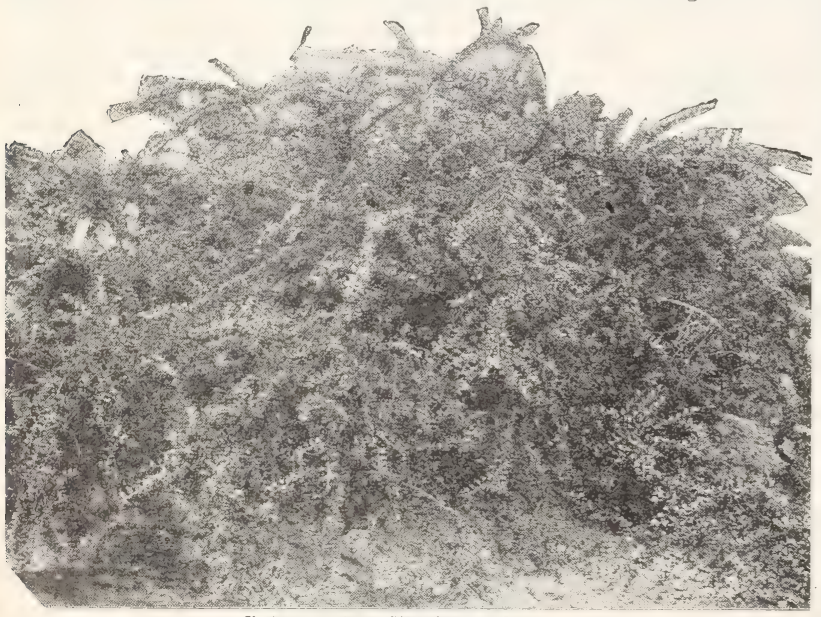

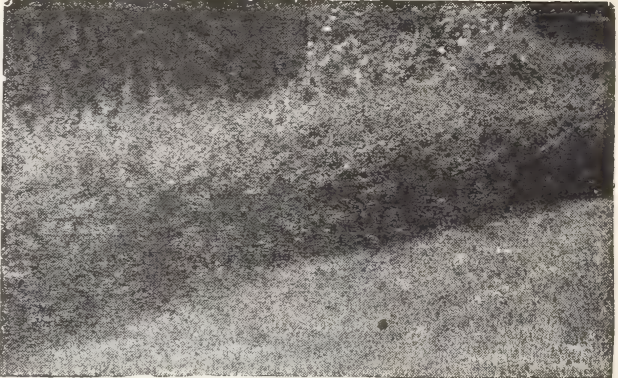

Barberry Hedge

\section{COLUTEA-BLADDER SENNA}

COIUTEA ARBORESCENS-July. Of com pact growth. Light green, acacia-like foliage; yellowish-red, peashaped flowers, followed by curious red, bladder-shaped pods. Hardy and good in any soil.

\section{CORNUS-CORNEL OR DOGWOOD}

CORNUS AIBA SIRIRICA-In the winter this is the most showy of a!l the shrubs, standing out bright and cheerful with its brilliant red bark. It should be planted in groups where its color effect is visible at a distance. It has healthy, compact foliage, white flowers and white berries. C. EIIGANTISSIMA VARIEGATA-A splendid variegated form of the above, with silver and green foliage.

C. AIBA SPAFTHI-One of the finest of recently introduced shrubs. Variegated with pale yellow and most distinct and valuable in all planting.

C. PANICUIATA (Panicled or Gray Dogwood) - July and August A bush with a multitude of finely-branched gray twigs and stems, the whole plant taking the form of a round umbel of twigs.

\section{STOIONIFERA AUREA (Golden-barked} Dogwood)-A striking contrast when planted with the red-barked variety.

\section{COTONEASTER}

A class of handsome fruiting shrubs only recently brought into general use. Their brilliant autumn foliage and vivid fruits adapt them to rockery and wall adornment, as well as to any usage in well drained soil with plenty of sunlight. DIVARICATA-6 ft. Oval, lus trous, fall crimsoning leaves. Fruits bright.

HORIZONTALIS - D e n s e ly preading, horizontal branches. Shiny oval leaves; persisting scar let fruits. Dwarf.

\section{CYDONIA}

JAPONICA (Japan Quince)One of the best known shrubs in cultivation. Very ornamental in early spring, as its bright scarlet flowers completely cover the branches before the leaves are formed. Makes a good hedge.

\section{DEUTZIA}

CRENATA-Double white flow. ers tinged with rose. Blooms the middle of June. Five feet high when fully grown.

GRACIIIS-A graceful and charming shrub with pure white flowers. Blooms the middle of June. Two feet high when fully grown. 


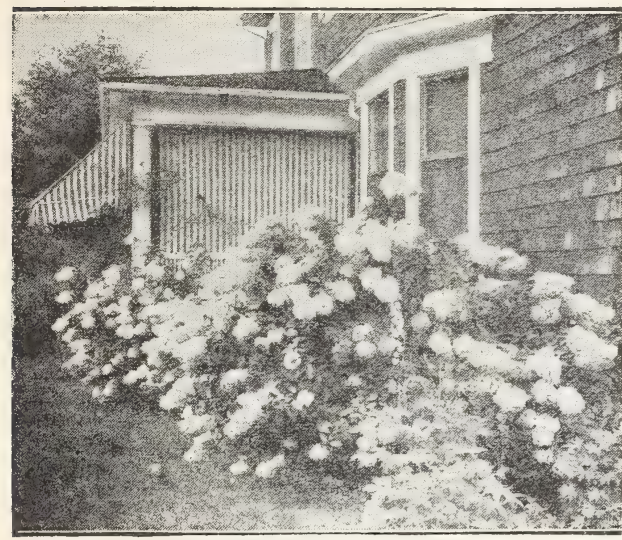

Hydrangea, P. G.

IFMOINE-An intermediate growing form with beautiful white flowers in clusters, covering the entire bush and blooming earlier than the other varieties.

MAGNIFICA - Of the Crenata type, erect pani. cles, double; a mass of pure white bloom in June. One of the best.

PRIDE OF ROCHFSTER-One of the finest varieties, producing large double white flowers, the back of the petals slightly tinged with rose. It excels all of the older sorts in size of flowers, profuseness of bloom and vigorous habit. Blooms early in June.

\section{ELDER}

AUREA (Golden Elder)-Contrasted with other shrubs, the golden yellow leaves of this European Elder give heightened effects in tone and color. Flowers white, in flat topped cymes. Grows nat urally 10 to 15 feet, but can be pruned into a neat, compact little bush.

\section{EUONYMUS - STRAWBERRY TREE} FUONYMUS AIATUS (Winged Burning Bush) A handsome shrub 6 to $8 \mathrm{ft}$. tall, with corky. winged branches. Native of China and Japan. Leaves oval, bright green fading in Autumn with gorgeous tones of red and crimson. Attracts attention wherever seen.

F. Europaeus (Spindle Tree)-May. Forms a low, round-headed tree, very compact. Foliage dark, associating well with the pendulous orange and red fruit of Autumn.

\section{FORSYTHIA}

GOIDEN BrIL-These splendid old shrubs growing 8 to 10 feet tall eventually, light up the garden with glinting masses of yellow, very early in spring before leaves appear. The upright forms make excellent tall hedges, and are bright. hued fillers for massed shrub groups.

FORTUNII-Growth upright, foliage deep green, flowers bright yellow. One of the best early flowering shrubs, the flowers appearing before the leaves. Hardy. Four to eight feet.

INTERMEDIA-One of the most floriferous shrubs, with slender, arching branches, and dark green, lustrous leaves. It blooms so early that it is frequently covered with its bright golden flowers while the ground is covered with snow. It is one of the very first promises of the bright and beautiful spring days to follow.

INTERIMEDIA SFECTABAIIS - The most showy form.

SUSPENSA-Long, curving branches; used for covering arches and trellises.

\section{FRINGE}

PURPIF-Also known as Purple Mist, Smoke Tree, and Smoke Plant. Covered during mid. summer with loose panicles of curious hair or fringe-like flowers, giving it a mist-like and novel appearance.

WHITE-A superb shrub, attaining a size of from ten to twenty feet. Has a compact, round ish form, large glossy leaves, and drooping ra. cemes of pure white flowers. Blossoms in May and June. An entirely different plant from the above.

\section{HONEYSUCKLES}

FRAGRANTISSIMA-Not a showy sort, but its early pink and white flowers are sweetly frag. rant, and its foliage remains until late in winter, if somewhat sheltered.

MORROWI-A spreading shrub with attractive white flowers, with brilliant red fruits in the fall PINK TARTARIAN-A well known shrub; flowers light pink, which appear in May.

RED TARTARIAN-Similar, but deep pink or red.

WHITE TARTARIAN-Like the preceding, but has white flowers.

\section{HYDRANGEA}

ARBORESCFNS GRANDIFIORA-A grand addition to summer flowering hardy shrubs dwarf. ing the show of others in July and August by the magnitude and profusion of its flower heads. The flowers are, in a large way, similar to the familiar "Snowball", in appearance, and are so conspicuously white and imposing that whether as single specimens, as cut flowers or in groupings, their presence is predominant.

PANICUIATA GRANDIFIORA-September. Bears immense cone-shaped heads of white flowers, turning later to shades of pink and red. Given plenty of water and hard pruning every fall, its heads of bloom attain immense size.

HYPERICUIM-See Perennials.

See back cover page for rare varieties and novleties, some of which can be obtained only from the Fremont Nursery.

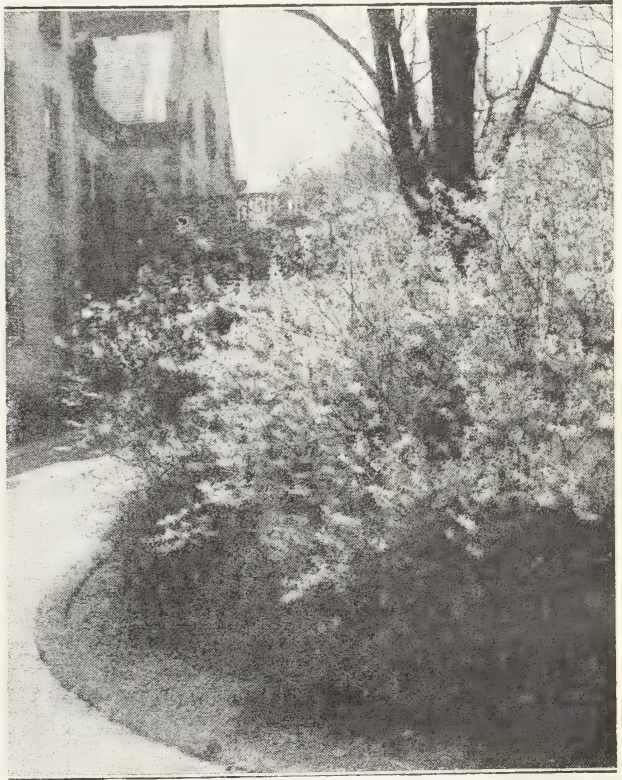

Forsythia 


\section{KERRIA}

JAPONICA (Globe Flower) - A slender branch. ed shrub, with bright green bark, growing 3 to 4 feet tall. Single bright yellow flowers. Very valuable.

JAPONICA FIORA PIFNA-An upright growing form, with double bright yellow blossom, re. sembling a small double rose. Sometimes called Double Yellow Rose. Blooms most all summer.

\section{LILACS}

Lilacs are too well known to need an extended description. They are hardy and free blooming.

\section{COMMON PURPIE-} COMMON WHITE-

The old-fashioned common purple and white lilacs.

PERSIAN-Attains a height of from 6 to 12 feet; small foliage; flowers bright purple. A native of Persia and a decided acquisition.

ROTHOMAGFNSIS-Similar to the preceding. VIIIOSA-Dwarf growth, broad leaved; pinkish lilac flowers in long loose panicles. Late.

FRENCF IILACS, Named-These are far superior to the common lilacs. Bloom earlier and much finer blossoms. Most of them are double. We have them in white and different shades of pink and purple.

\section{All double unless specified.}

Abel Carriere-Large, blue, reverse of petals rose. Belle de Nancy-Satiny rose with lighter center. Large.

Chas. X. - Single. Reddish purple. Very strong. grower.

Congo-Single, Long spikes of deep reddish purple.

De Mirabel-Single. Bluish violet.

LaTour d'Auvergne-Violet purple.

Mme. Abel Chatenay-Very large, pure white.

Mme, Edouard Andre-Clear rose.

Mme. Lemoine-White, fine and showy.

Marie Legraye-Pure white. Large panicles. The greatest forcing lilac.

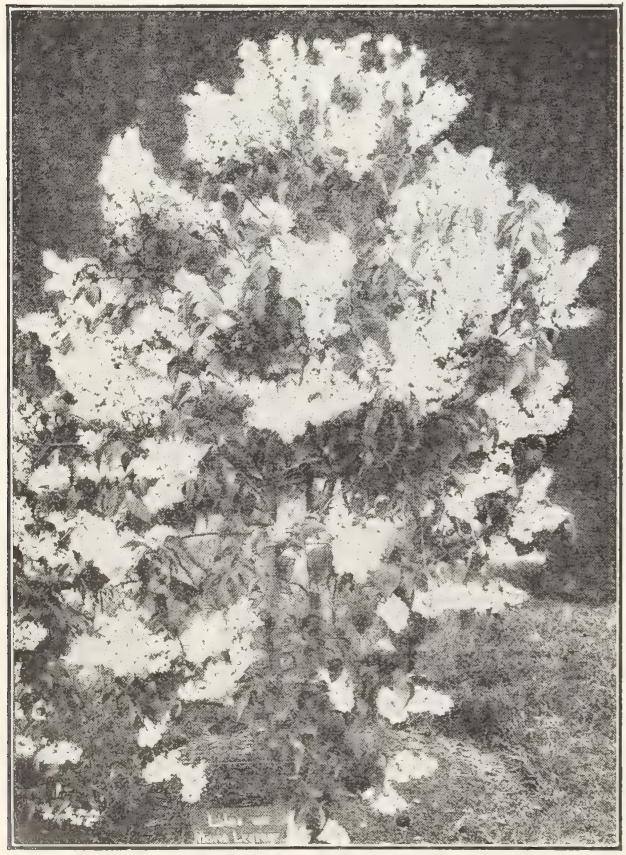

Marie Iegraye Iillac

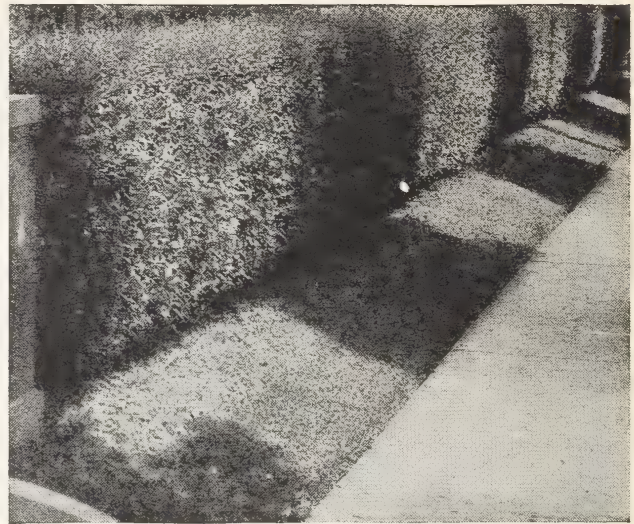

Privet Hedge

Othello-Single. Purplish red. Large trusses. President Carnot-Pale blue with white center. President Grevy-Blue, huge panicles.

President Viger-Bluish lilac. Extra fine.

Souvenir de Iudwig Spaeth-Very dark red. Long panicles. Single.

Vestal-Single. Enormous trusses of large perfectly formed pure white flowers. One of the very finest.

Waldeck Rosseau-Dark red.

\section{PRIVET}

CAIIFORNIA-Quick growing, straight, densely clothed shoots; the foliage in precise arrangement, a dark shiny green. The handsomest and most generally used of the entire group for hedging, clipped specimens, or for massing, but unfortunately not reliably hardy in the northern section.

FNGIISF (L. Vulgaris)-An old time garden type of informal habit. Gray-green bark and foliage, with white flowers and shining black berries.

IBOTA (Japanese)-Makes up into striking tall clumps, or informal screening hedges, with widespread curving branches; very vigorous and absolutely hardy. The foliage is grayish green; showy, fragrant white flower plumes in June, fol. lowed by persisting blue-black berries.

REGIIS-Resembles Ibota, except that it grows in a low spreading form.

\section{RHODOTYPUS KERRIOIDES}

WHITE KFRRIA-An attractive shrub 3 to 6 feet high, with beautiful yellowish green, corru. gated foliage and large, single white flowers late in May. The black seeds which follow are large and showy.

\section{RHUS-THE SUMACHS}

We can furnish the leading varieties of these as, Aromatica, Copallina, Glabra, Staghorn and Cut Leaved.

\section{RIBES-FLOWERING CURRANT}

AUREUM-Yellow flowers in long showy racemes with spice like fragrance.

\section{SPIREA}

The varieties which we catalogue are exceeding. ly fine and interesting shrubs. They are hardy, easily grown, and as they bloom at different periods one may have flowers all summer by planting the entire list.

ANTHONY WATERER-A new dwarf compactters and bush grows 4 to 5 feet tall, similar to growing shrub. Blossoms in broad, flat heads of beautiful deep red color. A perpetual bloomer.

BIIIARDI-Blooms nearly all summer; rosecolored; fine feathery plume. 


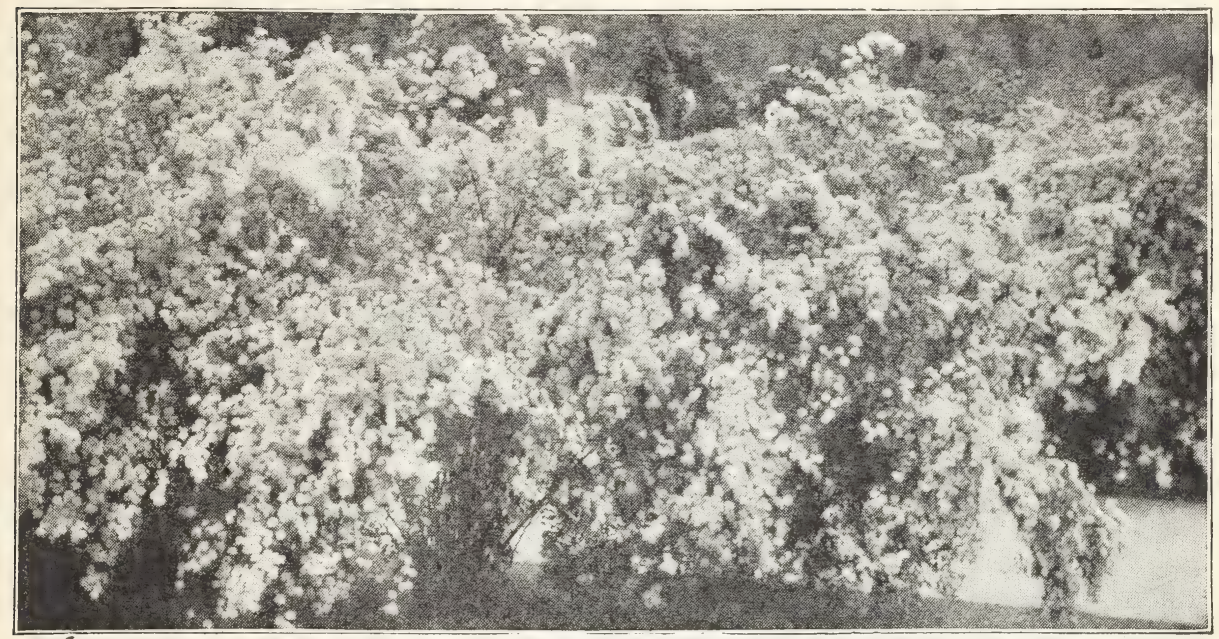

Spirea Van Houttel

FIIIARDI AIBA-White flowers, large clus ters and bush grows 4 to 5 feet tall, similar to Billardi, but white.

CAIIOSA AIBA-Dwarf. Of similar habit to the Anthony Waterer, but flowers are white.

FROEBFIS-Dwarf, 2 to 3 feet. Flat heads of crimson flowers from June to September. Extra fine.

GOIDEN-Very strong growing bearing an abun dance of fragrant flat clusters of flowers in June. Leaves bright yellow in the spring changing to a golden bronze in fall.

PRUNIFOIIA (Bridal Wreath)-The old-fashioned double flowered Spirea. Blooms very early, the long slender branches being covered nearly their entire length with small double flowers. Foliage a beautiful shiny green.

SORBIFOIIA (Ash-leaved Spiraea) - July. Handsome foliage, resembling the Mountain Ash. Long showy panicles of white flowers. A fine Spirea.

THUNBFRG'S-A Japanese species of small size, with narrow linear leaves, and small white flowers; one of the best dwarfs.

VAN HOUTTEI-The finest of all Spireas, a most charming and beautiful shrub; having pure white flowers in clusters. Extraordinarily profuse in bloom, and the plant is a vigorous grower and very hardy.

\section{STEPHANANDRA}

STEPFANANDRA, FIEXUOSA-An attractive shrub from Japan, of low, dense growth, with deeply cut foliage.

\section{SNOWBERRY}

WHITE-A well known, shrub with small, pink flowers and large, white berries that hang on fruit; fruit purple and hangs on all winter.

RFD-Red-fruited or Indian currant. A shrub of very pretty habit. Foliage, flowers and small fruit; fruit purple and hangs all winter.

\section{SYRINGA OR MOCK ORANGE}

BOUOUFT BIANC-One of the newest and best of all the Syringas. Bound to rank with the Spirea Van Houttei, when it becomes known, and as showy as the latter, when it blooms. Flowers pure white with a semi-double appearance and completely covering the bush with a mantle of graceful beauty. The most sweet scented of any Syringa that we have ever seen. Bush remains in bloom for several weeks.
CORONARIUS (Garland Syringa)-A well known hardy shrub. White, fragrant flowers. Blooms in June. Makes a large shrub.

GOIDEN IEAVED-A small shrub of positive and striking beauty. The foliage is golden yellow, and retains its lovely color through the entire season. When set with other shrubs the contrast is very pleasing. White flowers. Blooms in June, Very hardy.

GRANDIF'IORA-Foliage bright green; tall growing, pure white orange-like flowers in June.

VIRGINAIIS-A magnificent new variety. Moderately tall, with good foliage and compact habit. The flowers are the largest, handsomest and most sweetly fragrant of any known variety, with longest blooming season.

\section{TAMARIX}

AFRICANA-Of tall, slender, upright growth with feathery, asparagus-like foliage. Beautiful green appearance. Bright pink flowers in ra. cemes in May. Dark reddish-brown.

HISPIDA AESTIVAIS-Superior because of its abundant bluish foliage, and immense panicles of carmine-rose flowers in September. Quite dis tinct.

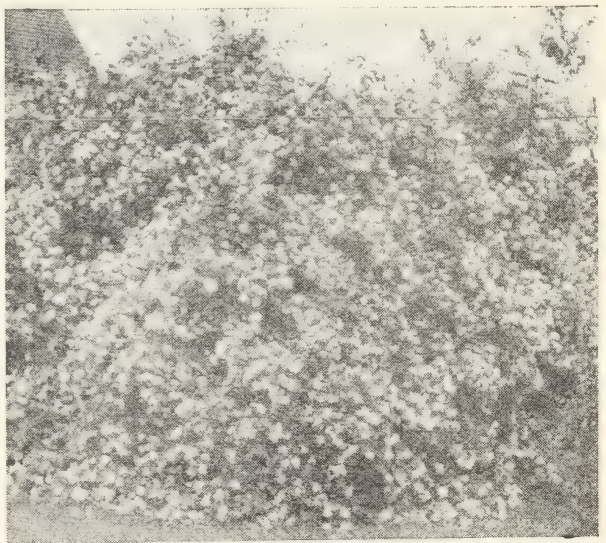

Philadelphus 


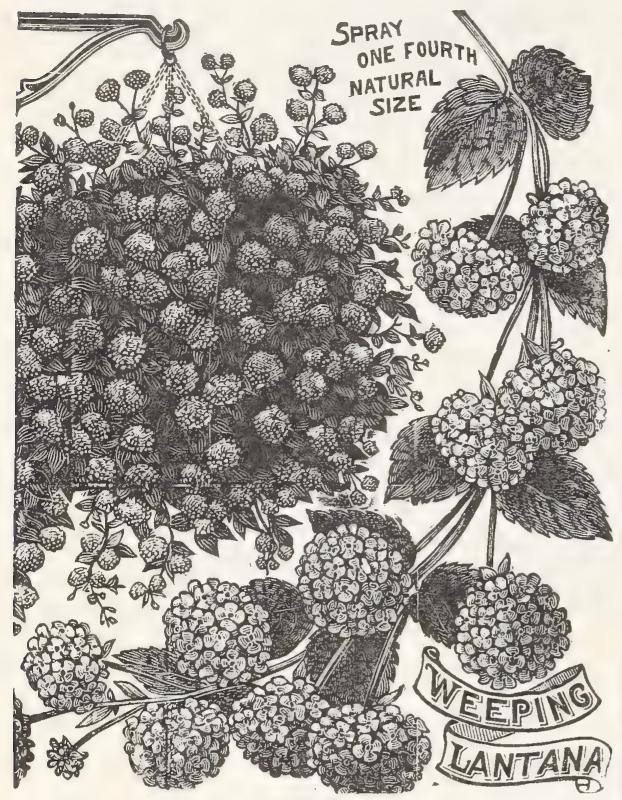

\section{VIBURNUM-ARROWWOOD}

CASSINOIDES (Withe-rod)-Height 4 to 8 feet, Broad, flat-topped panicles of creamy white in early summer, followed by pink berries which later change to blue.

DENTATUM (Arrowwood)-A l.ushy shrub with hrighi green, heart-shaped leaves, which change into rich purple and red. Creamy white flowers in flat cymes in late spring. Berries blue-black. Grows 8 to 12 feet in height.

IANTANA (Wayfaring Tree).-Grows 10 to 15 feet tall, with heart-shaped, crinkled leaves, and white flowers in May and June; fruits red.

IFNTAGO (Sheepberry)-Grows to be a small tree, 30 feet high. White flowers in cymes in May and June. Large, oval, blue-black fruit. OEUdus (High-Bush Cranberry)-A decora. tive native shrub, growing 8 to 10 feet high, with white flowers in May, followed by beautiful, showy clusters of scarlet fruits.

OPUIUS STrRILE (Common Snowball)-Well known; even more showy than the type, with its great clusters of scarlet fruits.

TOMENTOSUM-Flowers white, berries red to bluish black. Height 6 to 8 feet.
TOMENTOSUM PICATUM (Japan Snow: ball).-Handsome, plicate leaves and more delicately formed, white flowers in clusters; red fruit.

\section{WEIGELA}

Of Japanese origin, producing in June and July superb, trumpet-shaped flowers of various colors, from the purest white to the richest red; very ornamental in the fall.

CANDIDA - Is of vigorous habit, an erect grower becoming in time a large sized shrub; flowers pure white and produced in great profusion in June and the plants continue to bloom during the summer.

EVA RATHKE-New, One of the best of the Weigelas, the plants having a vigorous habit and flowers. Blooms several times during the season, bearing freely well-shaped, large crimson red flowers.

ROSEA-The best known sort. From China. Rose-colored, trumpet-shaped flowers. Blooms in June. Four to six feet.

VARIEGATED IFAVED-Leaves bordered with yellowish white, making the bush very conspicuous the entire season. Pink flowers blooming in June. A very desirable shrub.

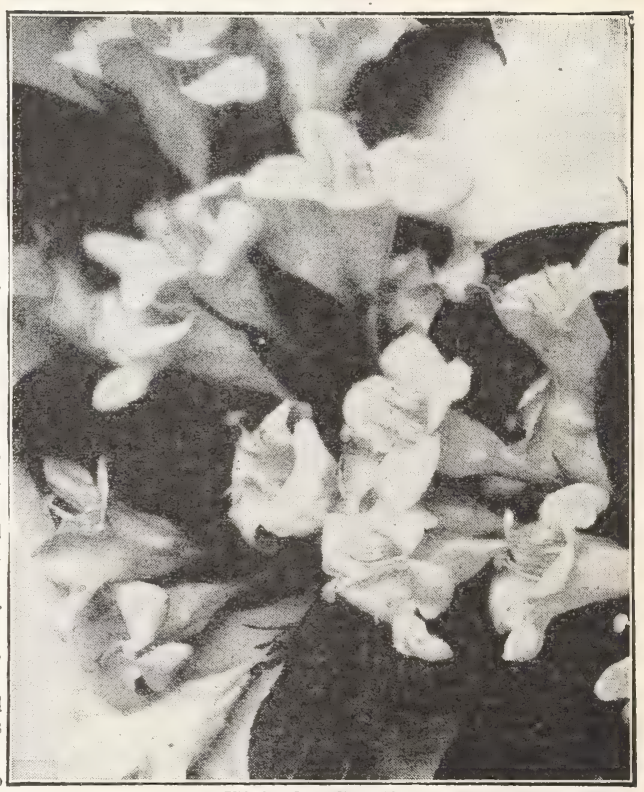

Weigela Candida

\section{HARDY CLIMBING VINES}

Ornamentals of this class are so hardy, so easily grown, and so beautiful that they deserve greater attention than they receive. No artist can produce pictures equal to the wealth of beauty displayed by the elegant wistaria, the graceful honeysuckle, or the charming and magnificent clematis when in the glory of full bloom, and there is nothing in art that will in any degree compare with the gorgeous hues of the Ampelopsis after it assumes its brilliant tints. 


\section{AMPELOPSIS VEITCHII}

BOSTON IVY-Leaves a little smaller and more ivy-like in form than foregoing. Overlapping each other they form a dense sheet of green. The plant requires a little protection the first winter until it is established, but after that it may be safely left to care for itself. It grows rapidly and clings to the surface of even a painted brick wall with great tenacity. Foliage changes to crimson scarlet in autumn.

\section{CLEMATIS}

FFNYRII-Fine bloomer; flowers large, of a beautiful creamy white, consisting generally of from six to eight petals. June to October.

JACKMANNI-This is the variety upon which Mr. Jackman bestowed his name. It is better known than any other, and still stands as one of the best. It is a strong grower and produce a mass of intense violet purple flowers from June to October.

VIIIE DE IYON-Flowers large, of a beautiful bright velvety red, very free flowering and continuous bloomer. The best red Clematis that we know of.

PANICUIATA-A great novelty from Japan One of the most desirable, useful and beautiful of hardy garden vines, a luxuriant grower, profuse bloomer, with fine foliage. Flowers medium size very fragrant, produced in great profusion in late summer.

RAMONA-A new American seedling Clematis. It is a free and perpetual blooming variety; both. on the old year's growth and also on the wood the current year; the color of the flower is a deep sky blue, and very attractive.

\section{EVONYMOUS}

RADICANS-One of the finest evergreen vines, with small, rich green foliage, and pink fruits. For covering rocky banks, rough walls, treetrunks, etc., also for vases, baskeis and borders of beds.

VARIEGATA-Foliage edged with creamy white, which takes on a pinkish tinge in winter.

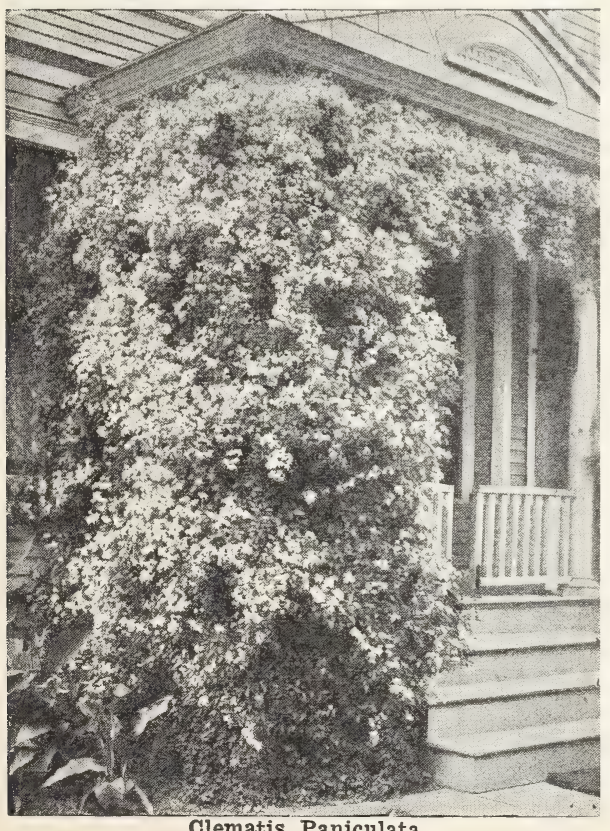

Clematis Paniculata

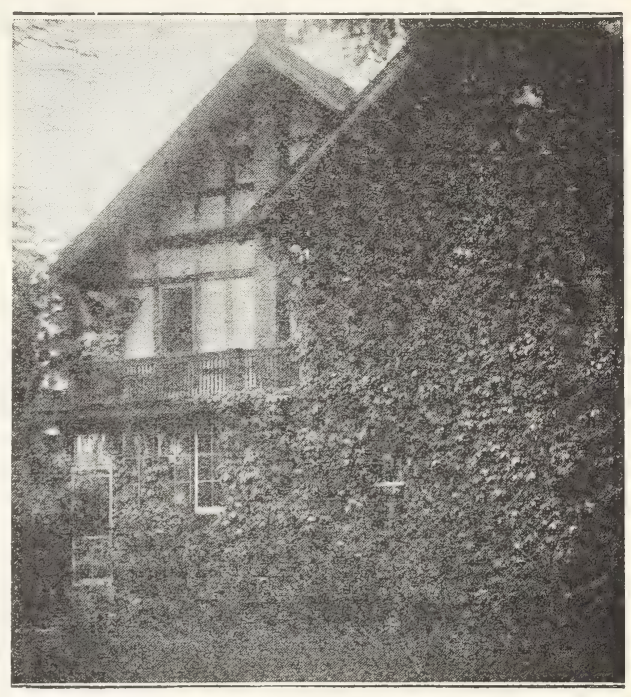

Boston Ivy

\section{POLYGONUM AUBERTI}

SIIVER IACE VINE-This is the latest addition to our list of practical hardy vines, a quick growing type of twining habit averaging 25 feet in a season. The small, rordate folinge is fres' and shiny, although the base of stalk becomes somewhat woody. Produces more bloom than any other hardy vine, covering a season extending from late summer into the fall with an extravagance of large, foamy sprays in silvery white.

\section{WISTARIA}

CHINESE PURPII-One of the most elegant climbing vines known, and a very rapid grower after it gets thoroughly established, sometimes making twenty feet of wood in a single season. Bears Jong clusters of pale blue flowers in May and June, and also in September. Extremely hardy. Attuins a larger size than any other climber.

Also Chinese White, a white form of the above.

\section{HONEYSUCKLE}

CHINESE TWINING-A well known vine holding its foliage nearly all winter. Blooms in July and September and is very sweet.

HALI' S JAPAN-A strong, vigorous evergreen variety, with pure white flowers changing to yellow. Very fragrant; covered with flowers from June to November.

MONTHIY TRAGRANT-Blooms all summer. Flowers red and yellow. Very sweet.

SCARIIT TRUMPET-Bright scarlet blossoms most all summer.

\section{HEDGE PLANTS}

AMRRICAN ARBOR VITAR-Forms a very handsome ornamental hedge of fairly dense growth.

BARERRRY (Japan Quince and Rugosa Rosa) - All makes fine untrimmed hedges.

NORWAX SPRUCE-With careful pruning may be kept low and in good shape, and grown in this shape is highly ornamental.

PRIVrT, California or Ibota (Chinese)-Are the leaders in hedges.

SCOTCH PIN Vitae-All well adapted for planting in belts for windbreaks. 


\section{EVERGREENS}

Every lawn, park, etc., should have at least a few of these beautiful specimens to give the bit of color that is needed to set off the rest of the planting. They are especially valuable backgrounds against which to group other trees and plants with beautiful colored leaves and branches.

Our Evergreens are exceedingly well rooted and the more rare varieties are taken up with a ball of earth on the roots. We never advise planting Evergreens in the Fall. We have recently added a line of the very rare and beautiful varieties, all of which are perfectly hardy, unless noted.

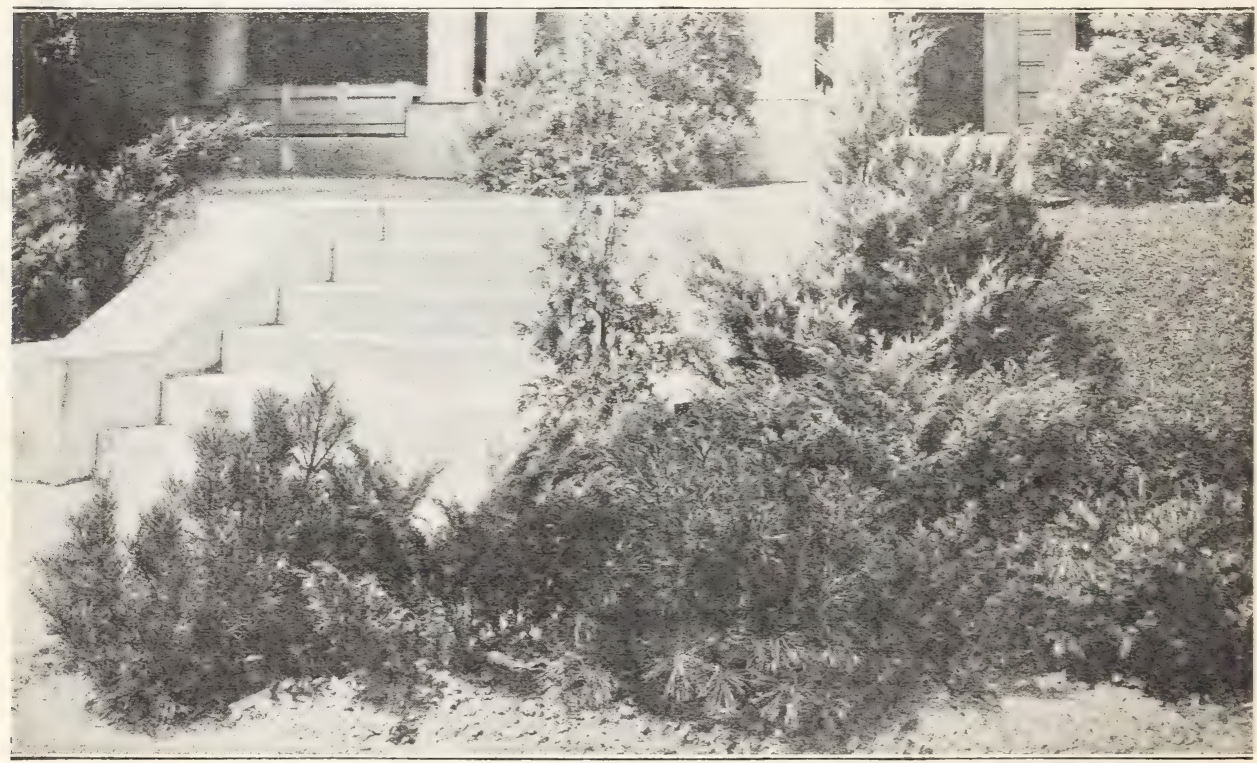

\begin{abstract}
ARBOR VITAE
AMERICAN-A native variety, valuable for hedges. Stands shearing well.

COMPACTA ARBOR-VITAE-This is a decid. ed globe type, growing as broad as it does high. Deep green foliage in summer.
\end{abstract}

ERICOIDES (Heath-Leaved Arbor Vitae). A very prettr dense little shrub of the Tom Thumb type

HOVEYI-Compact, dense and conical with light sellowish green foliage.

GIOBOSA-Similar to Compacta.

IUTמA (George Peabody)-Golden yellow, the entire season; grows in a pyramidal shape.

PYRAMIDAI-Grows in a beautiful prramidal shape. Heavy, dark green foliage; the best evergreen for cemetery purposes obtainable.

SIBERIAN ARBOR-VITAE ( $T$. Wareana)-A very dark green the entire jear and for this reason most popular.

TOM THUMB ARBOR-VITAE-This is an ex ceptionally dwarf-growing variety: globe shaped and seldom reaching 2 feet in height. It is very bright green in summer. changing to bronze in winter, being decidedly different from other varie. ties. Foliage very finely cut and lacy.

WOODWARDS Another globe headed variets similar to Globosa but a little more drooping.

\section{BIOTA (CHINESE ARBOR VITAES)}

The Biotas are a distinctive class of very beau. tiful evergreens, but should be planted where they will be slightly protected in our cold winters.
BIOTA AUREA NANA (Berckman's Golden Arbor Vitae) - Verr dwarf, one of the most beautiful. Golden yellow in summer, bright green in winter. Foliage arranged in lacy, flat vertical layers.

ORIPNTAI-The type grows bushy and tall Light green. Rapid grower.

ORIENTAI BAKERI-A fairly rapid, very compact, pointed cone shape of dark green color throughout the year.

ORIENTAI COMPACTA-A rery compact, dwarf type. Selected from more hardy stock.

ORIENTAI PYRAMIDAI A prramid shaped variety of rapid growth and bright green all win ter. One of the hardiest.

\section{FIR}

BALSAM OR AMIRICAN SIIVER A ver regular, symmetrical tree, assuming the conical form, even when roung; leaves dark green abore and silvery beneath

CONCOIOR A picturesque Colorado species long, leathery leaves, with glaucous tinge when young, becoming pale green with age. Branches arranged in horizontal whorls.

DOUGIAS-From the mountains of Colorado. A rapid grower, leaves light green abore, glau. cous below. Conical form, branches spreading, light and graceful.

\section{JUNIPER}

ChInzNsis (Chinese Juniper)-Pyramidal or columnar outline, foliage of a pleasing grayish green color when fresh, maturing to real dark green. 


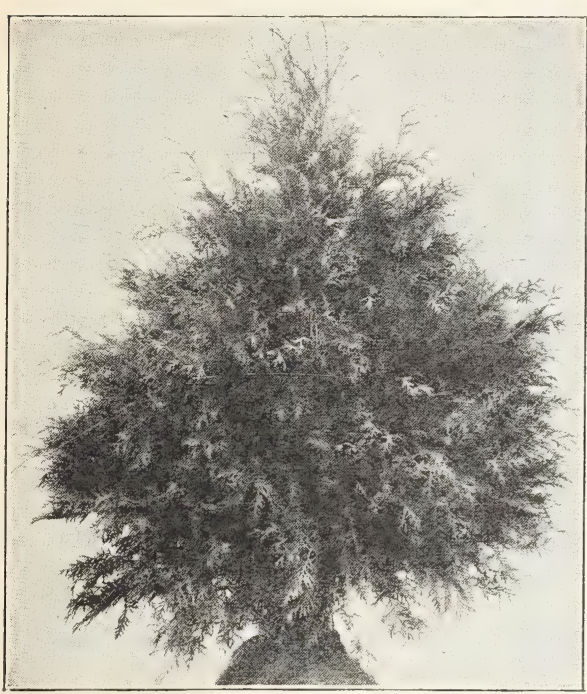

American Arbor Vitae

CHINENSIS MASCUIA-Compact, upright, pyramidal, rapid of growth. Grayish green color summer and winter. COMmUNIS (Common
shrub with spreading,
sometimes prostrate branches which curve upwards near the ends: widely distributed throughout the colder regions and mountains of the northern hemisphere.

COMMUNIS AUREA-Similar to the above but with yellow tips.

ENGIISH-Makes a dense pyramidal specimen: foliage, grayish green,

HORIZONTAIIS-A beautiful low growing prostrate form spreading out very close to the ground. Much used for rockeries and ground cover. Bright green.

HORIZONTAIIS GIAUCA-Similar in habit but with a silvery color.

IRISH-Erect, slender and formal in habit; foliage sage green, very compact; making a splendid column, sometimes 15 to 20 feet high; much used in cemeteries.

FFITZERIANA-One of the finest of the Juniper family. Graceful spreading branches, grace. ful in shape and fine in foliage. Very hardy and succeeds everywhere. The most satisfactory low spreading evergreen.

PROSTRATA (Creeping Juniper)-Valuable for ground covering in exposed sandy or rocky location. Usually low, with long trailing branches and numerous short, upright branchlets; a bright steel blue.

SABINA-Handsome moss green foliage; adapt. ed to use as a filler in Evergreen groups, its main branches protruding from the crown at a 45 degree angle; or as a dwarf ground cover grouped together fan shaped.

STRICTA (Excelsa or Greek Juniper)-This is an unusually attractive dwarf pyramidal form with very compact bluish green foliage. It is vigorous in growth and not particular as to soil. STRICTA VARIEGATA-Similar to above but having a number of white or creamy tips to the branches.

SWrDISH (Dwarf)-Dwaj:, compact, semi. pyramidal habit of growth; foliage light green, not changing in winter.
TAMARISCIFOIIA (Tamarix-leaved)-A beau. tiful trailing form of Savin, with bluish green foliage. The construction is dense and very fine like the tamarix foliage, especially attractive when showing new growth.

TRIPARTITA-A novelty, usually growing in three distinct bodies.

VIRGINIANA (Red Cedar)-Tapering form, bright, rich green foliage. Useful for ornamen. tal planting.

VIRGINIANA CANNARTI - A pyramidal, compact grower of medium size. Rich green heavily tufted foliage. A rare variety propagated by grafting. Has blue and silver berries in fall. VIRGINIAM GIAUCA-A beautiful and grace. ful tree with cedar like foliage of a distinct sil. very hue. The Blue Cedar, extra fine.

WAUKEGAN-A highly developed selection from Sabina Prostrata; ground-covering, closely compact. The beautiful silvery blue color as sumes a rich purple hue with the first autumn frosts.

\section{PINE}

SCOTCF-A fine, robust, rapid growing tree with stout erect shoots and silvery-green foliage. AUSTRIAN OR BLACK-A bush growing sort. Leaves long, stiff, dark green. Makes a large spreading tree.

WHITE-A native tree with light silvery foliage. ,The varieties of pines are especially valuable when tall windbreaks are desired. They are most rapid growing than other evergreens.

MUGFO (Dwarf Mountain Pine) - A very broad spreading variety, yet always retains a symmetrical shape. Fine for planting on stony banks, slopes, etc. Grows 6 to 8 feet high.

\section{RETINOSPORA-JAPAN CYPRESS}

FIUIFIRA (Thread-branched Japan Cypress) Slender, string-like, bright green foliage, drooping in long filaments. Graceful.

OBтUsA (Obtused-leaved Japan Cypress)Graceful, fern-like foliage, distinct and beautiful. OBTUSA CRIPPSII-A beautiful form of $\mathrm{Ob}$ tusa, very dense and a splendid light yellow color. OBTUSA GRACIIIS-A compact dark green foliaged sort of great merit.

OBTUSA GRACIIIS AUREA-Similar to the above but with golden foliage.

OBTUSA INANA COMPACTA-One of the fin est of the family in showy arrangements of foliage, very dwarf, dense, slow-growing habit, and great depth of color.

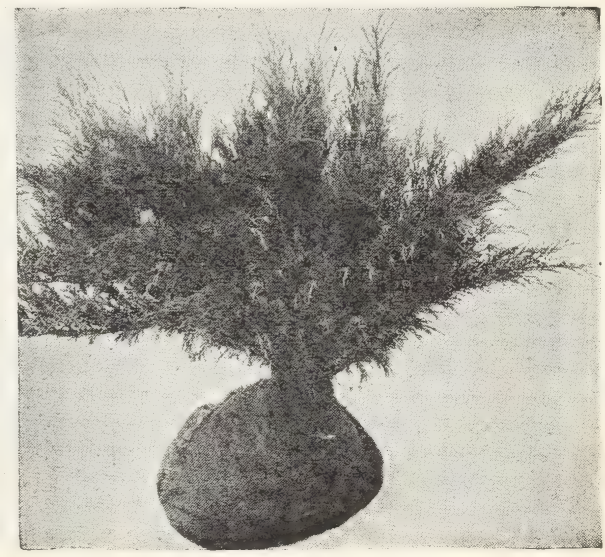

Juniper Sabina 
PIUMOSA OR PLUME IIKE RETINOSPORA-A beautiful tree having flat, featherfoliage of a light green color; stands shearing well.

FIUMOSA AUREA OR GOLDEN CYPREST - The most popular of all golden evergreens. Has soft plume-like golden foliage which is particularly bright in the spring.

PISIFERA-Cone-shaped foliage fine cut and rather drooping at tips. One of the best.

FISIFERA AURIA-T is has the same habit of growth as above, but all new growth is yellow or real light green. Looks something like an

Arbor Vitae.

SQUARROSA VEITCHII-Dense growth; soft beautiful silvery blue foliage, arranged in spirals which give the impression of boiling over. Shows to best advantage close against dark greens.

SQUARROSA SUIPFUREA-Similar to the above but with a sulphury hue.

\section{SPRUCE}

BIACK HIIIS-A very dense growing variety of more slow and compact growth than the Nor way. Many trees have a glaucous tinge.

COLORADO SPRUCP-A magnificent tree, with brilliant foliage that makes it a striking object in any landscape. Hardy in any exposure, of vigorous growth and elegant habit, with broad, plumy branches, often regularly set in whorls.

COLORADO BLUE SPRUCE-Selected speci mens from the Colorado seedlings, which haie developed a strong, distinct blue sheen. This con spicuous tree is of extra value for specimen or group planting; second in importance only to its grafted form, the aristocratic Koster's Blue, or the newer and improved Moerheims.

\section{KOSTER'S BLUE SPRUCE}

Previously considered the best of the Blue Spruces. Foliage is silvery blue, densely crowded on the many branches. We have paid particular attention to getting the absolutely true stock of this famous tree and can guarantee its true color and character. Supply is very limited.

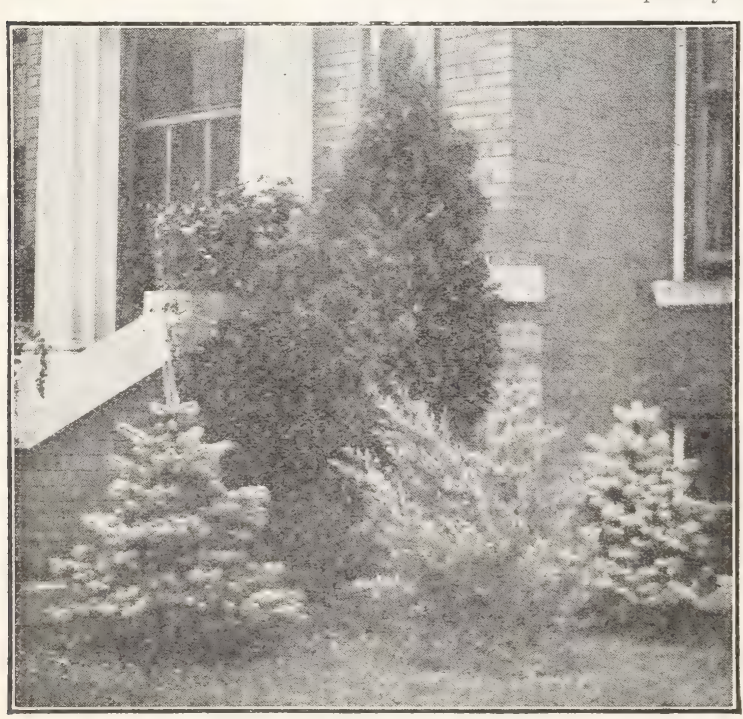

An Evergreen Planting
MOFRHEIMS BUUE SPRUCE-Recently im. ported from Holland. An improvement on Kost. ers. The best blue of all. See last cover page.

HEMIOCK SPRUCE-A graceful tree, with loose, open growth and rew-like foliage. It can be kept in dense form if pruned. Prefers moist soil. One of the very best evergreens to plant.

NORWAY-Of large and lcfty appeirance. Well adapted for large enclosures, and stands pruning well when used for hedges. It is exceedingly picturesque and beautiful; very popular and de. servedly so. We supply thousands of these for Christmas every year.

\section{TAXUS-YEW}

The Yews are choice. dwarf evergreens, densely clothed with small, blackish green leaves. Fertile specimens have scarlet berries in autumn.

CANADENSIS (American Yew)-A low, weep ing, broad, spreading bush, dark green foliage and crimson berries. Entirely hardy, and very valuable for surfacing beds or forming groups.

CAFITATA-An upright growing form of Cus. pidata.

CUSPIDATA (Abrupt-leaved Japanese Yew)Uprigh growth and dense, vers dark foliage. Valuable because it is especially hardy and rich in appearance.

CUSFIDATA BREVIFOIIA COMPACTA-A very dwarf compact form with shorter leaves than the other forms. Very hardy and very valuable where a real dwarf is wanted.

CUSPIDATA BREVIFOIIA IMPROVID-A form similar to the above but much faster grow. ing.

\section{EVERGREEN SHRUBS}

BOXWOOD-A limited supply of true Boxwood.

KAIMIA-Mountain Laurel, the native variety found in the mountains of Pennsylvania and the Carolinas.

MAFONIA-Aquifolium. Holly-leaved Mahonia. Sometimes included under berberis. Handsome native evergreen of medium size, with shining, prickly leaves and showy, bright yellow flowers in May, followed by bluish berries. Quite useful in decorative planting for its neat habit and fine bronze-green leaves.

PACHYSANDRA TERMINAIS (Japanese Spurge)-One of the best ground covering plants, particularly valuable in shade, averaging 6 to 8 inches in height and branching freely into a dense mat. Its shapely indented foliage is practically evergreen; thick. rubbery, lustrous dark green. It bears small spikes of light colored flowers during May and June.

CAROLINIANUM - A native variety of the Carolinas. Dwarf rose colored.

CATAWBIENSE-A native

Lavender pink.

MAXIMUM-Pink and white.

HARDY GRAFTED VARIETIESA very limited supply.

Evergreens are especially used for distinctive specimen lawn trees, massing, windbreaks screens, hedges and backgrounds for flowering shrubs and other blooming plantings. 


\section{PERENNIAL PLANTS}

There is an ever increasing demand for hardy perennials and rock plants and to keep pace with this demand we have constantly increased our plantings each year till we are now growing a very complete line of all the best varieties.

Our soil produces a splendid plant with a splendid root system.

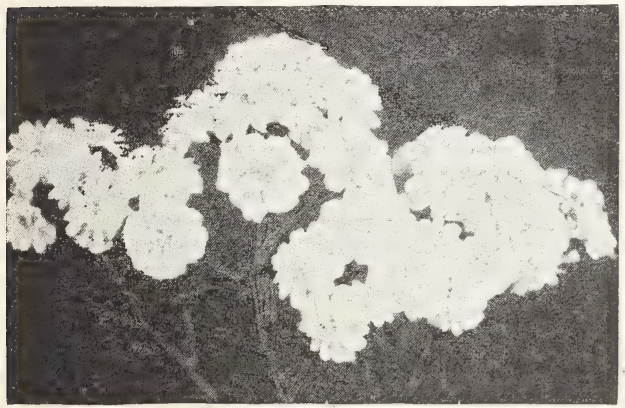

Achillea

ACHILEA (Milfoil or Yarrow)

Plants suitable for dry, sunny places. The dwarf kinds are useful for carpeting or for rock. eries; the taller varieties as border plants.

MIIIEFOIIUM ROSEUM (Rosy Milfoil)July to October. Rosy pink flowers in dense heads, on stems 18 inches high. Effective on edge of shrubbery or in border.

PERRY'S WHITE-1 to 2 feet. June to September. A choice new variety; pure white flowers over one inch across; broad, overlapping petals. Nothing better for cutting.

PTARMICA, BOUIE DE NEIGE-New. An improvement on "The Pearl", with fuller and more perfect flowers. Best for borders.

\section{ACONITUM (Monkshood)}

Summer and late Autumn-flowering plants with bold spikes of hood-shaped flowers, thriving in either sun or shade. The roots are poisonous and should not be planted where the tubers might be mistaken for vegetables. Delivery from October 15 th to March 15th. Tubers cannot freeze.

FISCFERI-A dwarf variety with pale blue flowers. 18 inches. September.

NAPEITUS (True Monkshood) -3 to 4 feet. July to August. Large dark blue flowers in a raceme.

NAPEIIUS CARNEUM-2 to $2 \frac{1}{2}$ feet. July. August. This variety has variegated red and white flowers; effective.

SPARKS' VARIETY-July and August-flowering; tall branched spikes covered with deep blue, Monkshood flowers.

\section{AETHIONEMA (Persian Candytuft)}

Near relatives of the Candytuft, these hardy little rock plants are of the most fascinating character. The foliage of most of them is a beautiful, glaucous blue; stems woody, and when covered with their heads of pink blossoms, make a picture not to be forgotten. They are almost shrubby in habit, and are improved by a slight cutting back after blooming. Stony, sandy loam j. suitable for them and a warm, sunny position. Given these conditions, they will grow more beautiful every year.

GRANDIFIORUM-Strong, twiggy bushes, cov* ered with long, slender spikes of rosy pink flow. ers. One of our best rock plants. 9 inches.

PERSICUM-Somewhat deeper in color than Grandiflora.

\section{AGROSTEMMA (Rose Campion)}

Stout, erect growing plants with silvery foliage, which contrasts well with the showy flowers, which are produced during June and July. CORONARIA (Mullein Pink)-Bright rosy crimson. $2 \frac{1 / 2}{2}$ to 3 feet.

\section{ALYSSUM (Rock Madwort)}

Very popular for beds, borders and winter flow. ering; of easiest culture and very free blooming Seed may be sown very early in the spring and up to June 15 th, also in the fall for early spring blooming.

ARGRNTEUM-Dense growth. Leaves silvery beneath, flowers yellow in clustered heads, all summer. About 15 inches.

AXATILE COMPACTUM-Broad masses of bright yellow flowers in early spring. An excellent plant for the rockery or front of borders. 1 foot.

\section{ANCHUSA (Alkanet)}

For producing a mass effect of brilliant blue, the Anchusas cannot be surpassed. Dropmore, the darkest one, is most effective. They should be treated as biennials, as the old plants exhaust themselves at the end of two or three years. They reproduce themselves, however, from selfsown seed. The blooming season can be extend. ed for several weeks by cutting the spikes as soon as the flowers fade, thus preventing seeding.

DROPMORE-Tall spikes of beautiful blue flowers, flowering all summer. Rough, broad foliage. 4 to 5 feet.

\section{ARABIS (Rock Cress)}

AIPINA-Pure white flowers produced in dense masses, splendid for border and rockery work, and last quite some time when cut.

\section{ANEMONE (Windflower)}

Valuable plants suitable for massing or single specimens. They grow rapidly and are profuse in bloom, gaining strength and beauty each year. The blooming period extends from August till mid-Nov e $m$ b e $r$, the large, op e $n$ flowers fur nishing abund ant cut flow ers and a bril liant field display. Cover plants in winter. We offer strong, fieldgrown $\mathrm{r} 0 \mathrm{ot}$ only.

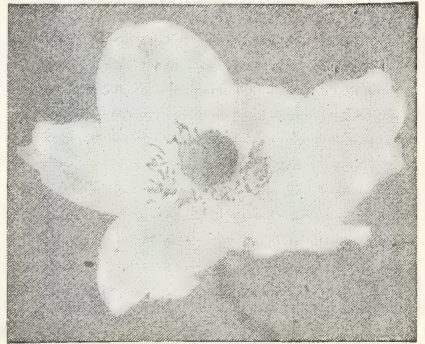

Anemone
AIBA-Purest white, with yellow center, 2 to 3 feet.

QUEFN CHARLOTTr-Abundant semi-double flowers, broad and perfectly formed. "La France", pink. 2 to 3 feet.

WHIRIWIND-Excellent double white flowers. 2 to 3 feet.

\section{AQURLEGA (Columbine)}

As in cut flower the Long-Spurred Aquilegias are the daintiest of our outdoor grown flowers. They come in blues, whites and yellows, and shades of pink and rose in strains reasonably 


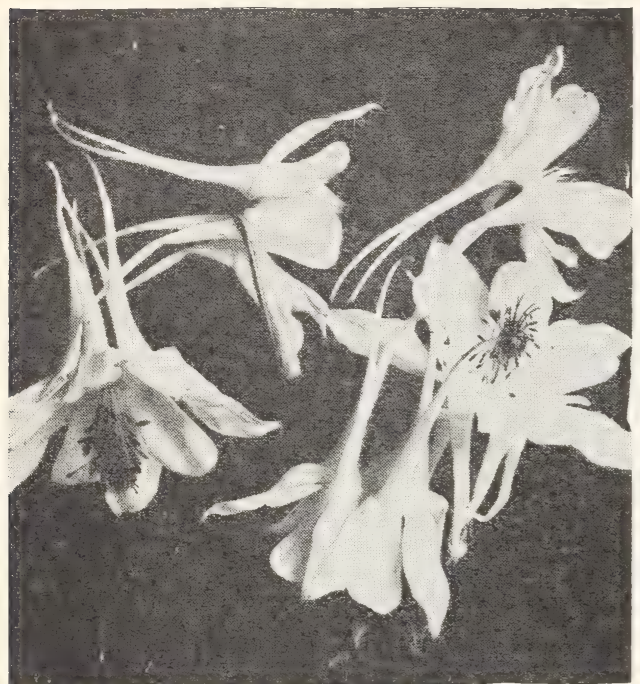

Aquilegia

true. Practically all the various shades and col ors are in the Coerulea Hybrids. They remain in bloom for a long season and are vigorous and long lived. They are not at all particular as to soil or location, although they prefer a sandy loam and a moist but well drained, sunny posi tion, and usually make themselves at home in any hardy border or rockery. Their period of flowering covers the late spring and early sum mer months. Taken as a whole, they are a most important part of the hardy garden, and should be grown in quantity by every lover of old-fashion. ed garden flowers.

CHRYSANTHA-Beautiful golden yellow flowers; blooms for two months.

COERUTEA-Blue shades.

IONG-SPURRED HYBRIDS, MIXTURE-

ARMERIA (Sea Pink or Thrift)

Attractive dwarf plants that will succeed in any soil, forming evergreen tufts of bright green foliage, from which innumerable flowers appear in dense heads, on stiff, wiry stems, from 9 to 12 inches high. They flower more or less continuously from early spring until late in the fall. Very useful in the rockery and border edgings.

MARITIMA HYBRIDS-3 to 6 inches. June to October. Large flowers of delightful white rose and pink shades. Very useful for edging and cutting.

\section{ARTEMISIA (Sage Brush)}

IACTIFIORA-A tall-growing plant of fine foliage and heads of small white flowers in Aug. ust and September, which fill the garden with fragrance. A splendid and graceful cut flower.

\section{HARDY ASTERS (Michaelmas Daisies)}

The many species, widely distinct from each other in habit and form, are with a few excep tions, all native of North America. It is in Europe, however, that our Asters have been most highly appreciated. Many improvements have been made by European growers, and many hybrid forms have been produced by crossing the different species. For the best results, they require division and replanting every third rear. CIIMAX-One of the best and showiest, with large, pyramidal spikes of large, light lavenderblue flowers; very free. 5 feet.

FRICA-A beautiful clear pink; large double flowers.
GLORY OF COIWAII-Good sized, almost double; ageratum-blue flowers.

MRS. RAYNOR - The deepest red of all Asters. PERRY'S WHITE-The finest white Michaelmas Daisy yet introduced; perfect in habit and remarkably free flowering. The stout stems are well branched and covered with flowers $2 \frac{1}{2}$ ins.

\section{ASTILBE (Perennial Spirea)}

Hybrid varieties of very vigorous growth, producing many branched, feathered heads of flowers in June and July. They prefer a half-shady, moist position in any ordinary garden soil. We offer 3 year old, large, field-grown clumps only, for immediate effect.

AMERICA-Deep pink; excellent forcing variety; fine for early forcing.

BETSY CUPRRIUS-Splendid new variety, growing 5 feet high. The fine drooping flower spikes 2 feet long, show in summer during some weeks a great number of white flowers with pink center.

BRUNFIIDE-A great improvement on the variety Venus; the thick flower spikes are crowded with clear lilac flowers.

GRUNO-This new Astilbe grows 4 feet high and produces light and graceful spikes of spread. ing habit and has a splendid salmon-pink color. Award of Merit R. H. S. of Holland.

QUEEN OF HOLIAND-Very fine, delicato bluish white.

RUBENS-Posy red; new and good; fine for forcing.

VISTA-New. Tall, lilac rose spikes; beauti. ful garden variety.

BAPTISIA (False Indigo)

AUSTRAIIS-Dark blue, pea-shaped flowers in June; suitable for the hardy border or wild garden. Very attractive foliage. 2 feet.

\section{BLEEDING HEART (Dicentra)}

SPFCTABILIS-An old-fashioned favorite; its long racemes of graceful heart shaped pink flow. ers are always attractive; it is used largely for forcing and is perfectly at home in any part of the hardy border, and especially valuable for planting in clumps.

\section{CARYOPTERIS (Blue Spirea)} MASTACANTHUS INCANA - A handsome hardy perennial; grows about 3 feet high and produces rich lavender blue flowers in great profusion the whole length of the branches. A valuable plant either for bedding or pot culture, blooming continuously from early in September until cut by frost.

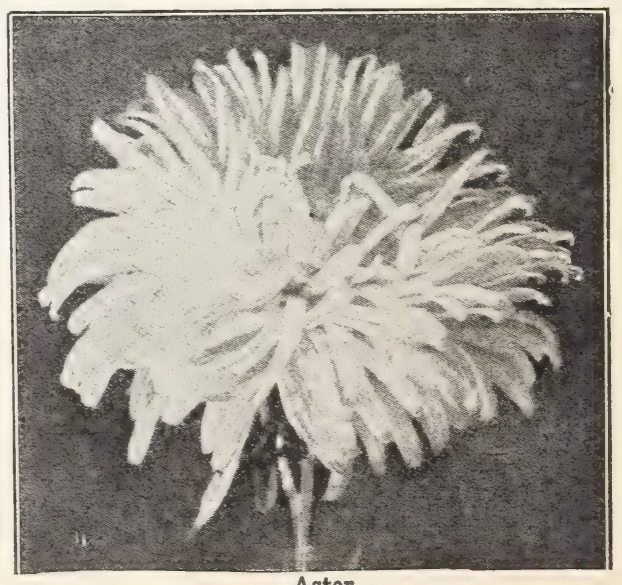




\section{CERASTIUM Snow-in-Summer)}

TOMPNTOSUM-A low-growing plant having silvery white foliage and producing an abundance of snow-white flowers. Especially suitable for rock or border purposes.

\section{CAMPANULA (Bellflower)}

Indispensable hardy garden flowers, of much variety of form, some being of tall and imposing habit, while others are dwarf, compact little plants, suitable for edging, rockwork, etc. They like a good, rich soil, and last much longer in bloom if planted in a half-shady place.

\section{PERSICIFOIIA GRANDIFIORA ALBA} (White)-One of the finest Campanulas, with large, handsome white, bell-shaped flowers. A great acquisition. Height 2 feet.

PERSICIFOIIA GRANDIFIORA COERUIFA (Blue)-An excellent companion to the white variety, the large bright blue flowers making an effective contrast. Height 2 feet.

PERSICIFOLIA GRANDIFIORA COFR UIEA FIORE PIENO-Double-flowered form of the above.

\section{CAMPANULA MEDIUM}

\section{(Canterbury Bells)}

These imposing herbaceous hardy biennials are profusely covered with large, bell-shaped flowers; extremely showy in shrubberies and mixed borders. Height 3 feet. Plants potted in October make most beautiful plants for the conservatory and greenhouse in the spring, coming into flower, without being forced in any way, about two months before those in open ground.

CALYCANTHFMA (Cup and Saucer)-Large semi-double flowers, each resembling a cup and saucer.

Pink-Beautiful variety; charming pink flowers. White-Similar to preceding, but flowers are white.

Blue-

\section{CARNATION}

(The Truest Hardy Outdoor Carnation)

No florist should be without them. A beautiful strain of hardy pink, which resembles most of all the indoor Carnation, blooming in great abund. ance all summer, in the most magic colors, flowers being semi to full double. Excellent for cutting and very hardy.

Pink, Red, White, Yellow and Grenadin Red.

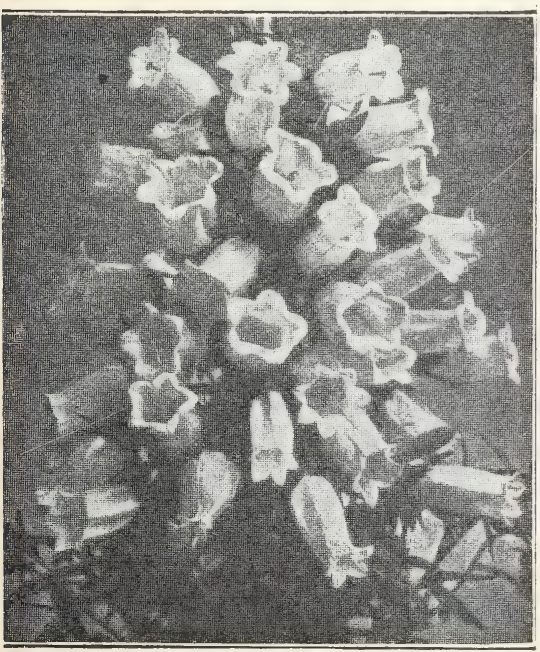

Canterbury Bells

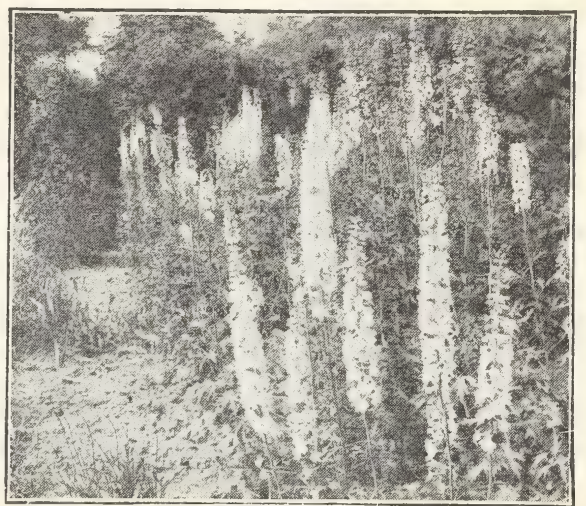

Delphiniums

CHELONE (Shellflower)

Handsome perennials, growing about two feet high, and bearing numerous spikes of large flower heads, summer and fall.

IYONI-Heads of showy purplish red flowers.

COREOPSIS (Tickseed)

GRANDIFIORA-An improved variety with large, bright yellow flowers; one of the best hardy plants. Fine for cut flowers all summer long.

CIMICIFUGA (Snakeroot)

RACEMOSA-Handsome species bearing in July and August spikes of pure white flowers; well suited for planting at the back of border, or for naturalizing at the edge of the woods. 4 to $6 \mathrm{ft}$.

CHRYSANTHEMUMS (Hardy Garden) Everyone knows these handsome and lasting flowers that come when most other flowers are gone. We have these in White, Yellow, Red, Pink and Indian Red and also the Pom Poms in Yellow, Bronze and Pink.

DELPHINIUM (Larkspur)

BELIADONINA-They are our best blue cut flowers, are perfectly hardy and established plants produce a number of spikes, giving three crops during the season. They are in demand by every florist for decorating, the light blue Belladonna combining especially well with other flowers. BEIIAMOSA-A dark blue of the type of Belladonna with the color of the old Formosum variety, but not liable to mildew like the latter and of stronger growth.

CFINESE-A very pretty variety, with the feathery foliage and intense gentian-blue flowers in open panicles. CHINESE AIBUIM-A pure white form of the above. FORMOSUM-The old-fashioned dark blue Larkspur. TAII. FNGIISF HYBRIDS-Unquestionably the finest strain of mixed hybrids ever offered. A grand assortment of single and double flowers. Colors ranging from lightest blue to purple, with flower spikes two feet long.

DESMODIUM (Tick Trefoil)

PENDUIIFIORUM-An exceedingly graceful shrublike plant covered with purplish red flowers in summer time when little else is in bloom. Strikingly beautiful.

\section{DICTAMNUS (Gas Plant)}

The Dictamnus is one of the most satis hetory hardy plants in cultivation, both on account of splendid flow ers and its rich, durable foliage.

FRAXINIIIA AIBA-White.

FRAXINEIIA RUBRA-Reddish.

\section{DIGITALIS (Foxglove)}

A grand display of thimble-shaped flowers in immense spikes during June and July. Tall growing with large rough foliage. Very showy in the garden. Separate colors. White, Rose and Purple. 
GIANT SHIRIFY FOXGLOVES-They are a genuine "Shirley', production of extraordinary size and vigor, growing 5 to 6 feet tall. The flower-heads are over 3 feet long, crowded with big, bell-shaped blossoms. Colors range from white and shell-pink to deepest rose, many attractively dotted with crimson or chocolate.

DIANTHUS (Hybrid Garden Pinks)

DIANTHUS PIUMARIUS (Clove Pinks)Pink purplish and white, fragrant flowers on long spikes. Handsome, glaucous green foliage. For border or rock garden. It will bloom continuously if flowers are cut off when they begin to fade.

SEMPERFUORENS FIORE PIENO-Double and single blooms. Blooms throughout the summer.

DIANTHUS BARBATUS (Sweet William)The Sweet William is a fine plant which produces great masses of bloom of extremely rich and varied colors. The flowers are lasting and fine for cutting.

\section{ERYNGIUM (Sea Holly)}

Finely cut, spiny foliage and thistle-like heads of flowers of a beautiful steel blue. Very decorative in the hardy border and useful for dry bouquets in winter.

AMITHYโTINUM (Syn. Oliverianum)-The true blue Thistle, with amethyst stems and bracts. GIAUCUIM ROSEUM-With heads of pink cones.

\section{EUPATORIUM (Hardy Ageratum)} COEIESTINUM-A pretty hardy plant, with light purple flowers similar to Ageratum; in Hower from August until frost. 18 to 24 inches. Good cut flower.

\section{FUNKIA (Plantain Lily) (Day Lily)}

The plantain Lilies are among the easiest plants to manage; their broad, massive foliage makes them attractive subjects for the border even when not in flower. They succeed equally well in sun or shade.

COFRUIFA-Broad green leaves; blue flowers SUBCORDATA GRANDIFIORA-Very large pure white, lily-shaped, fragrant flowers in August and September.

VARIFGATA-Variegated foliage; blue flowers. Beautiful edging plant.

\section{GAILLARDIA (Blanket Flower)}

These are among the showiest and most effective hardy perennial plants, and shculd find a place in every hardy border, also splendid for cutting; 2 feet.

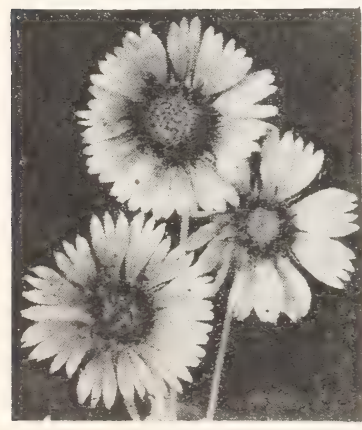

Coreopsis
GRANDIFIORA COMPACTA - A compact variety, forming b u s h y plants 12 to 15 in ches high, and bearing long-stemmed flowers well above the foliage. In coloring the flowers are as rich and varied as those of the tall-growing sort.

GRANDIFTORA K E R IM E S INA SPIENDENS

Rich crimson, nar row canary-yellow border.
GRASSES (Hardy Ornamental)

The ornamental Grasses can be used with tell. ing effect in borders, large beds, or by the margin of ponds and lakes. They are often used with

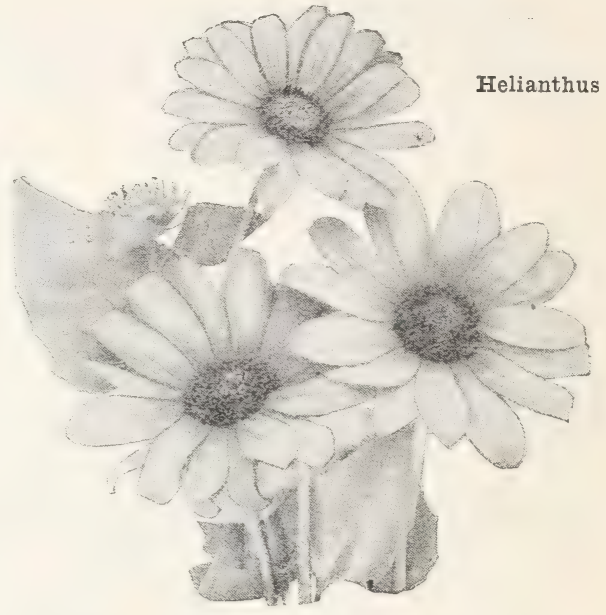

small shrubs and medium sized trees in wide borders. The Eulalias planted singly on lawns where the soil is de p and rich. take care of themselves and grow very rapidly into large specimens.

EUIAIIA GRACIIIIMA UNIVITTATA (Japan Rush) - Graceful habit, with very narrow foliage; of a bright green color, with a silvery midrib. 6 to 7 feet

FUIAIIA JAPONICA-Long, narrow, graceful green foliage, and when in flower the attractive plumes are 6 to 7 feet high.

EUIAIIA JAFONICA VARIEGATA-Very ornamental; long, narrow leaves, striped green, white, and often pink or yellow.

EUIAIIA JAPONICA ZEBRINA (Zebra Grass) - The long blades of this variety are marked with broad, rellow bands across the leaf. It makes a very attractive specimen plant for the lawn. 6 to 10 feet.

\section{GYPSOPHILA (Baby's Breath)}

Very branching or spreading, slender plants. with scant foliage when in bloom. Of easiest cul ture in open, rather dry places. Desirable where a mass of delicate, misty bloom will fill in a bare place.

PANICUIATA COMPACTA-When in bloom in August and September it forms a symmetrical mass 2 to 3 feet in height and as much through, of minute white flowers having a beautiful gauze-like appearance.

\section{HELENIUM (Sneezewort)}

Tall-growing plants closely allied to the Sunflower; bearing in late summer and fall great masses of large, daisy-like flowers in shades of vellow and orange.

AUTUMNATE SUPERBUM-Broad heads of deep golden yellow flowers in late summer. Grows 5 to 6 feet high.

AUTUMNAIE RUBRUIM-A splendid new variety; deep bronze-red, changing to terra cotta. 5 to 6 feet. September.

FUMILUM MAGNIFICUM-Large, golden yel low flowers; one of the most floriferous and useful border plants in cultivation. Early flowering from July to October. Can be successfully used in place of Coreopsis where a more uniform type of plant is required; dwarf in habit; 12 to $18 \mathrm{ins}$. RIVERTON GEIM ( $\mathrm{New}$ ). Old gold, suffused with bright terra cotta, changing to wallflower. red. August to October.

\section{HELIANTHUS (Hardy Sunflower)}

The perennial Sunflower should always be planted in masses, where they may have plenty of room, against backgrounds of shrubbery, or nat. 


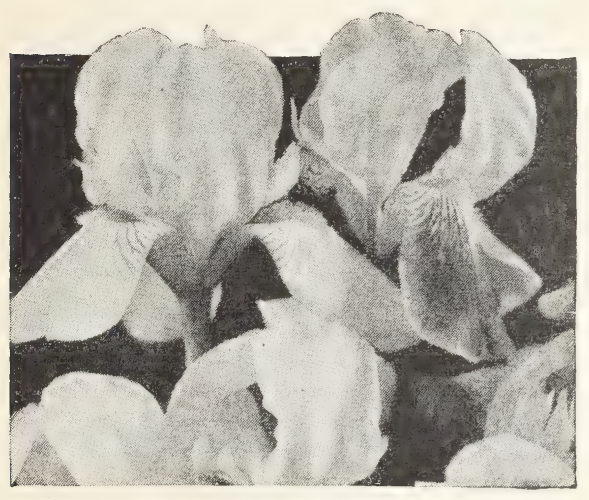

German Iris

uralized in wild gardens or woodlands. They produce a grand effect impossible to describe. In combination with hardy Asters, where broad color effects are wanted in late summer, they have few equals. They are profuse bloomers, producing an unlimited supply of flowers for decoration.

MAXIMIILIANI-The latest of all. Golden yellow flowers in graceful sprays in October. Fine for cutting. 6 feet.

MUITIFIORUS FI. PI.-Clear yellow; close ly resembling a Dahlia in shape and finish. $4 \mathrm{ft}$ SPARCIFOIIUS-The best of the summerblooming varieties of hardy Sunflowers. Flowers 3 inches in diameter and freely produced. Plant grows 3 to 4 feet high, and spreads rapidly. Fine for the border, and for planting among shrubs.

\section{HELIANTHEMUM (Rock or Sun Rose)}

Low-growing evergreen plants, forming broad clumps, and which during their flowering season. July to September, are hidden by a mass of bloom: for the front of the border, the rockery, or a dry, sunny bank. Helianthemums belong to the finest border or rock plants, but field grown plants should be trimmed back before planting, as they are otherwise hard to establish.

CIARA MIDDIETON-Single, rich orange.

FIREBAII-Bright scarlet, double.

MUTABIIE-Golden yellow; single.

HEMEROCALLIS (Yellow Day Lily) FIA VA (Lemon Lily) - Sweet scented, clear. full yellow; $2 \frac{1}{2}$ feet. Flowers in June.

\section{HEUCHERA (Coralbells)}

Beautiful plants for front row of borders, with slender, fairy-like spikes of richly colored flow. ers; most striking in the garden and light and graceful for cutting.

BRIZOIDES-We have thoroughly tested this new Heuchera and find it one of the most desirable hardy plants introduced in many years. It has the same foliage and habit as Heuchera sanguinea, but the color is not so brilliant, though five or six times as many flowers are produced and stems are much longer. Blooms nearly all summer.

\section{HOLLYHOCKS}

For a number of years we have been growing an improved strain of Chaten Double Hollyhocks. Long spikes, beautiful shades and very double. Many have told $u$ s they were prettier than roses. Double White, Red, Pink, Salmon, Maroon and Yellow.

\section{HIBISCUS (Mallow)}

MAIIOW MARVIIS--A robust type of upright habit, producing an abundance of flowers of enormous size in all the richest shades of crim. son, pink and white.
NEW GIANT-FLOWERING MARSHMAL IOW-A wonderfully improved form of our greatly admired native Marshmallow or Rosemal low, in which not only the colors have been great ly intensified, but in which flowers of enormous size, frequently 10 to 12 inches in diameter, have been developed. Equally at home in all positions, having the same vigor in dry and wet ground perfectly hardy and are very floriferous, blooming from early in July until late in September. They are the most beautiful and hardy of all herbace ous plants, their dignified spikes of hugre blossoms make them indispensable for large groups and mixed borders. We offer three distinct colors Red, Pink or White and Crimson Eye.

\section{HYPERICUM (St. John's Wort)} MOSERIANUM-A most desirable border plan of free and graceful habit, producing long, slender, much branched stems, leafy to the base and all drooping towards the ends, apparently from the weight of the flowers and buds, although the flowers face so none of their beauty is lost. It is marvelously free-flowering, of large size, measuring from 2 to $2 \frac{1}{2}$ inches in diameter; in color a rich golden yellow, rendered still more effictive by the numerous yellow stamens and crimson anthers, and blooms continuously the entire sea son. 2 feet.

\section{IBERIS (Hardy Candytuft)}

Most desirable dwarf plants, 8 to 10 inches, with evergreen foliage, which is completely hid den with dense heads of flowers early in the spring.

LITTIE GEIM-Dwarf, pure white flowers in June. Glaucous blue foliage. Splendid rock or edging plant; perfectly hardy. 6 inches.

SEMPER VIRENS-Very dwarf and covered with-a sheet of white, a particularly fine rock plant.

IRIS KAEMPFERI (Japanese Iris)

The flowers of the Japanese Iris are often 8 to $10 \mathrm{in}$. in diameter and of remarkably varied and beautiful color's. They thrive best in a rich and

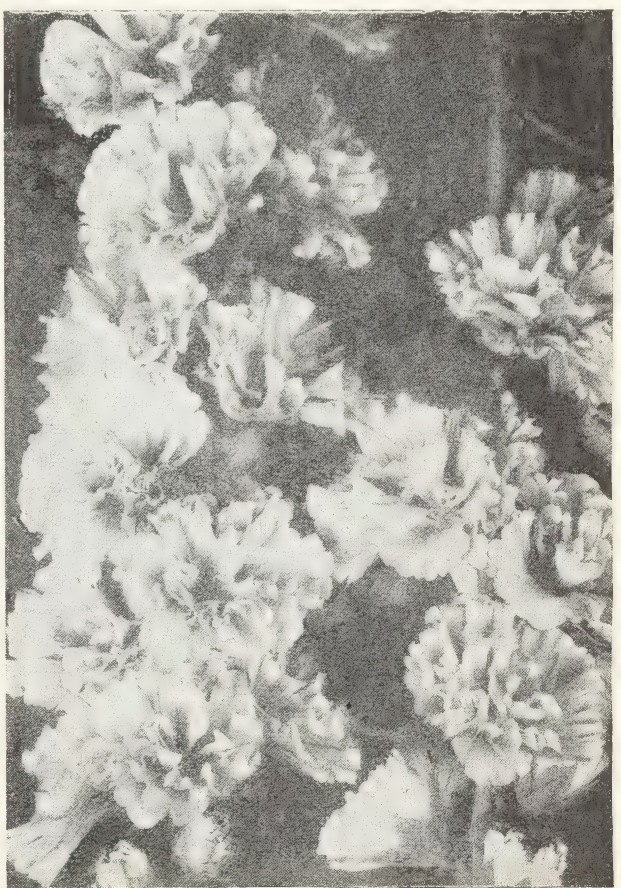

Hollyhocks 
somewhat moist soil. The blooming season is from the middle of June to about August 1 Flowers on long stems and resembling a lily. As the names of the Japanese Iris are meaningless and not dependable we list most of them by color only.

Mottled Blue-Very free flowering.

Blackish Purple-Extra large

Deep Purple-White throat.

Gold Bound-White, yellow center.

Reddish Purpla-Yellow center.

Hannibal-White striped with blue.

White-Striped pink.

Robt. Craig-Blue and lavender, yellow center Koko-No-Iro-Crimson purple, yellow veined.

IRIS (German)

The Iris is one of the finest, if not the finest, of our hardy plants. Not particular as to soil or location, but asking only that the sin shine on it. It throws up spikes of bloom that are mar. velous in their delicacy of structure and the colorings which are exquisitely dainty are wonderful in their blending and variety. We have a very fine collection consisting of the following:

Berlioz-Lavender, yellow throat.

Canary Bird-Canary yellow.

Candelabra-Standards light mauve, Falls violet veins, converging to a dark violet blotch at the ends.

Cherion-Fine pink.

Darius-Standards yellow, Falls blue.

Florentina Alba-White, slight bluish tinge.

Her Majesty-Pink

Honorable-Yellow, Falls brown.

Isolene-Very large, silvery lilac, Falls mauve.

Johan De Witt-Purple with reddish tint.

Kharput-Deep violet purple, late.

Lohengrin-Verv large, deep violet mauve.

Mad. Chereau-Frilled white petals, edged with light blue.

Mad. Paquette-Rosy claret, nearly red.

M'Aime-White, streaked with blue

Maori King-Rich yellow, velvety falls, edged with yellow.

Midnight-Dark deep purple, very early.

Mrs. Reuthe-Lavender.

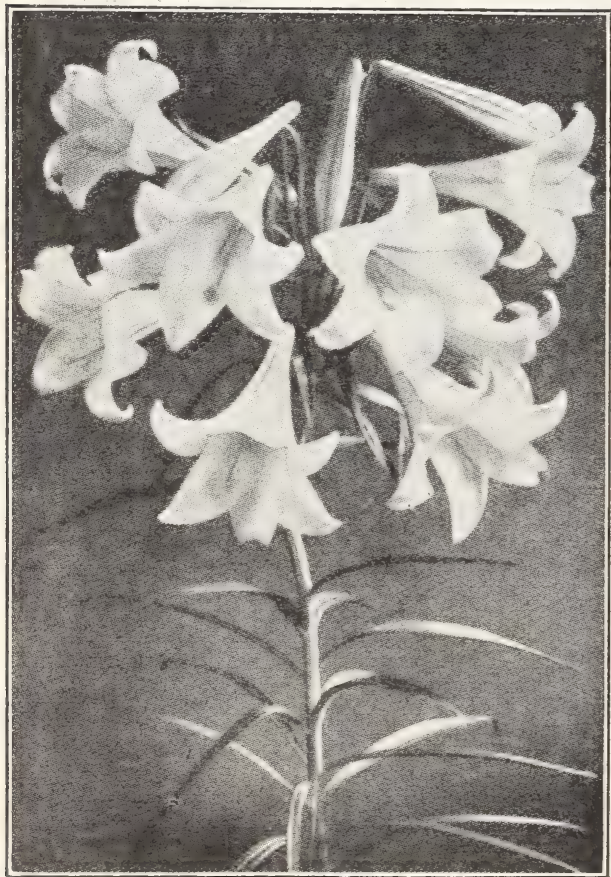

Regal Lily
Niebelungen-Yellow, Falls violet purple.

Oriflamme-Light blue, Falls violet purple.

Pallida Albert Victor-Tall, clear sky blue. Fine

Pallida Dalmatica-Similar to preceding.

Prosper Laugier-Light bronze red, Falls ruby purple.

Pumilla-Dwarf, dark violet.

Siberian-Snow Queen, white.

Gen. Wallace-Blue.

Native-Pseuda Acorus, yellow.

LATHYRUS (Hardy Sweet Pea)

Perfectly hardy, making a very heavy growth each summer and blooming nearly all season. Splendid for covering arbors, fences, etc. We can furnish them in red, pink and white.

\section{LAVANDULA (Lavender)}

VRRA - This is the true Sweet Lavender; grows about 18 inches high; delightfully fragrant blue flowers in July and August.

\section{LINUM (Flax)}

A desirable plant for the border or rockery, growing 2 feet high, with light, graceful foliage and large flowers all summer.

PRRENNE-Very attractive, both in foliage and bloom. Flowers beautiful pale blue on slender, graceful stems.

\section{LOBELIA (Indiana Paintbrush}

Handsome border plants, thriving in any ordinary garden soil, but preferring a moist, deep loam. Season August till late September.

CARDINAIIS (Cardinal Flower)-Rich, fiery cardinal flowers. Strong plants, often producing ten to eighteen spikes, 24 to 30 inches long.

LYCHINS (Campion) (Ragged Robin)

A fine old-fashioned flower, bearing large heads of brilliantly colored flowers, that liven up the border during summer and early autumn.

VISCARIA FIORE PIENO-A fine double variety; fine for cutting.

VISCARIA SPIENDFNS-Brilliant red.

\section{LILIUM (The Lily)}

With a well-selected collection, Liliums may be had in bloom from June to October. They should be planted in the fall, from October 1 as long as the soil can be worked; and in spring, as soon as the frost is out of the ground until the first of May. Plant about 5 inches deep.

I. AURATUM (Golden Rayed Lily of Japan)Ivory white ground, thickly strewn with purple studs; the center of each petal has a band of light golden yellow extending from tip to base The most magnificent of lilies.

CANDIDUIM (Madonna or Annunciation Lily) This is the old-fashioned garden Lily, and one of the most beautiful. Ready in September only. First size.

REGAIE OR MYRIOPHYIIUM (The Regal Lily) - It is absolutely hardy, and is excellent for forcing. It has been predicted that this will become the Easter Lily of the future, and being so hardy, may be grown at home. The flowers are white slightly suffused with pink, with a beautiful shade of canary-yellow at the center. and extending part way up the trumpet. It is delightfully perfumed, reminding one of the Jasmine, and lacking the heavy, oppressive odor of most Lilies. Blooms out-of-doors early in July. SPECIOSUM AIBUM-Large, white flowers of great substance, with a greenish band through the center of each petal.

SPECIOSUM RUBRUM-White, heavily spot. ted with rich crimson.

TIGRINUM FIORI PIENO (The Double Tiger Lily) - The only double Tiger Lily worth growing.

\section{LUPINUS (Lupines)}

The Lupines produce beautiful long spikes of pea-shaped flowers a foot long on stems three feet high. They are perfectly hardy but cannot endure drought, and must be planted in well prepared garden soil and kept watered in dry weath er. Can furnish in Pink, Blue or White. 


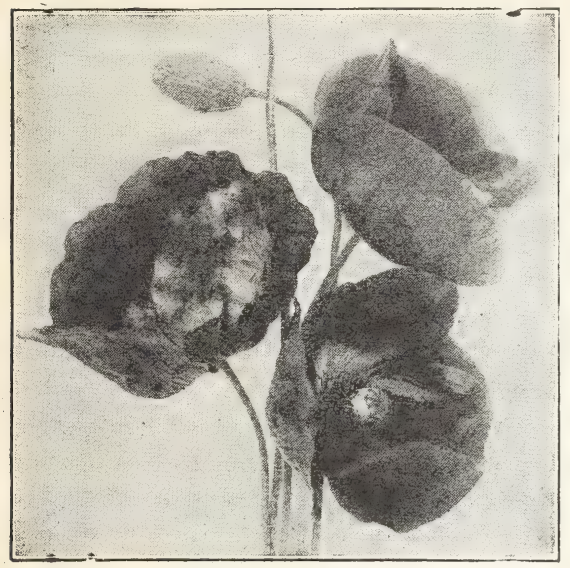

Oriental Poppy

LYTHRUM (Purple Loosestrife) SUPFRBUM ROSEUM-Very showy; splendid for banks of streams and ponds.

\section{MONARDA OR BERGAMOT}

(Oswego Tea)

Showy plants growing from 2 to 3 feet high, succeeding in any soil or position, with aromatic foliage, and producing their bright flowers during July and August.

DIDYMA, CAMBRIDGE SCARIRT-Brilliant crimson-scarlet.

\section{MYOSOTIS (Forget-me-not)}

Nearly everyone is familiar with the Forgetme-not which makes such beautiful pictures in the garden in early spring. They are alike charming in the border, rock garden, or by the waterside. They all like shade and a fair amount of moist ure: use them freely as a ground cover for your Tulip or other bulb beds.

PAIUSTRIS SEMPERFIORENS - L a $r \mathrm{~g}$ e, rich blue flowers with yellow eye; a charming plant for damp places and a more profuse bloomer than the Alpestris.

PACHYSANDRA (Japanese Spurge) TFRMINAIIS-A trailing plant 6 to 8 inches high, forming broad mats of bright glossy green foliage. A ground cover, which will grow in all shady situations and the only plant which will thrive under pine trees. Some of its main uses are: Under all evergreen plantings, under all shrub plantings, for areaway copings, for loggia and enclosed porch uses for shrub and flower bed borders, for bordering walks and drives, for steep terraces in sun or shade, for city yards it is ideal for dense shade under any kind of trees.

\section{PAPAVER (Poppy)}

There is no class of hardy plants which has risen so much in public favor as the perennial Poppies, all of which are most striking and useful both in the garden and in a cut state.

ORIFNTALE (Oriental Poppy)-Tremendous scarlet, cup-shaped blooms of brightest crimsonscarlet, with large, purplish black blotches at base of petals, ereating a wonderful contrast when bloom is fully open. Clumps of these throughout the border add a brilliancy that no other flower can provide.

ORIENTAIE, MRS, PERRY-Orange-apricot; very fine.

PAPAVER NUdicAule (Iceland Poppy)

The plant is of neat habit forming a tuft of bright green fern-like foliage, from which spring, throughout the entire season, a profusion of slender, leafless stems 1 foot high, each graced with charming cup-shaped flowers. Double.
PHYSAIS FRANCHFTI (Chinese Lantern Plant)-An ornamental variety of the Winter Cherry, forming dense bushes about 2 feet high, producing freely its bright orange-scarlet lantern like fruits. Used extensively by florists for $\mathrm{Hall}$. oween decorations.

PHYSOSTEGIA (False Dragonhead) VIRGINICA-Forms large clumps 3 to 4 feet high, bearing long spikes of delicate pink flowers, tubular in form. July and August.

PHLOX (Hardy)

ATCESTE-Blue, white veined.

ATHIS-Deep saimon.

BARON COMFTE-Deep velvety red

BRIDESMAID-White with crimson eye

CHAMPS FIYSEF-Rosy magenta.

COQUEICOT_Scarlet.

COUNT VON IASBURG-White.

CREPUSCIF-Mauve, carmine center.

ECIAIREUR-Large deep red.

FDMUND ROSTRAND-Purple, white eye. EIFFEI TOWER-Pink, red eye.

FERD CORTEZ-Deep crimson and bronze. F. A. BUCHIER-White, striped pink. GIPFION-Pink, red eye.

JOAN OF ARC-White.

IOTHAIRE-Salmon.

MISS IINGARD-Early waxy white.

MRS. JENTINS-Large white.

MRS. INGAIIS-Lavender.

PANTHEON-Clear bright pink.

PERCHEAU D'ISIAND-Deep red.

PROF. VIRCHOW-Bright carmine and orange. RIEINIANDER-Salmon pink, claret eye.

RICHARD WAIIACE-White, red eye.

RIJNSTROOM-Rose pink.

ROSNNBFRG-Reddish violet, red eye.

SUNSET-Bright red.

TERRA NEUVA-Lavender.

VIGO MARIE-Dwarf, white, pink eye.

WIDAR-Dark violet, white eye.

\section{NFW VARIETIFS}

BRIIIIANT-Bright scarlet, large.

COCCINFA-Large salmon with brilliant scar let eye. Extra fine.

COMMANDER-Brilliant red. Grand.

DEUTCFIAND-Glittering orange carmine, deeper at center.

FEUERBRAND-Enormous trusses, orange scar let.

MRS. ETHEI PRITCHARD-Very large, rose mauve.

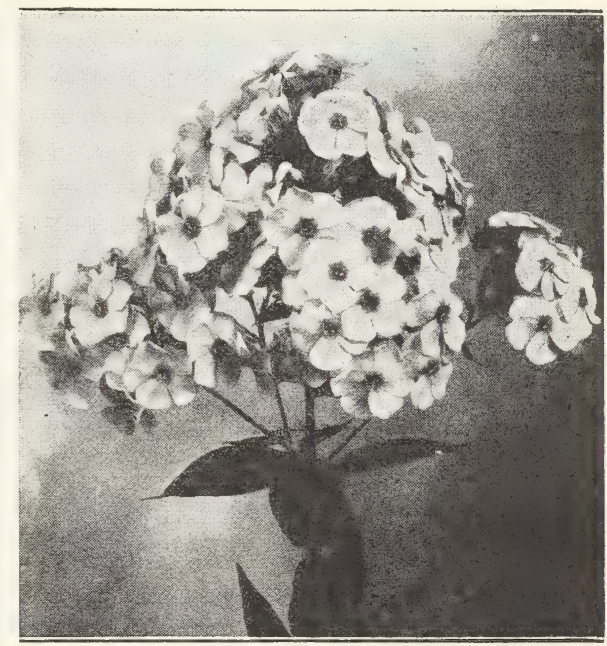

Hardy Phlox 


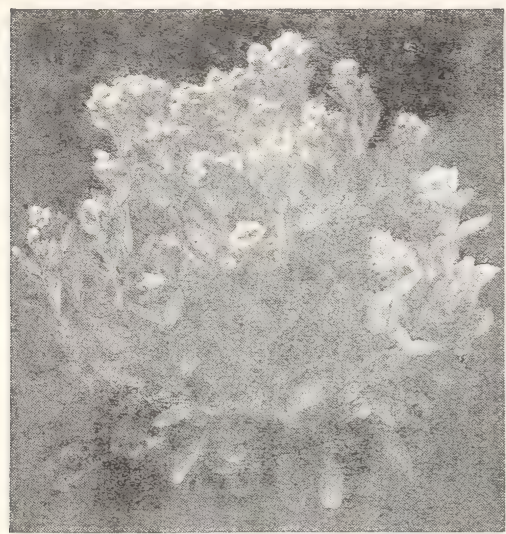

Sedum

PLATYCODON (Balloon Flower) GRANDIFIORA-Blue, 18 inches. June to October. Large. showr, deep blue flowers. Good for rock garden and border.

GRANDIFLORA AIBA-White-flowered form of the above.

\section{PLUMEAGO (Leadwort)}

IARFENTAE-One of the most desirable bor der and rock plants. It is of dwarf, spreading der and rock plants. 6 to 8 inches high, covered with deep blue flowers during the summer and fall.

PYRETHRUM (Persian or Painted Daisy)

Too much cannot be said in favor of this grand hardy perennial. which will thrive in any good garden soil where there is good drainage and full exposure to the sun. The main season of blooming is in June. but if the old flower stems are removed they will give a fair sprinkling of flowers in the autumn. Splendid for cutting. Mixed colors, mostly red and pink.

\section{SAPONARIA (Soapwor $i$ )}

OCYMOIDES SPIENDENS - Pretty border and rockery plant: flowers rosy pink.

\section{SAXIFRAGA (Megasea}

CORDIFOIIA-These will thrive in any of soil and in any position. Grow about foo high, and are admirable for the front of the bor der or shrubbery, forming masses of handsome, them useful; flowers appear very early in the spring. Fine among rocks or ledges.

SCABIOSA (Pin Cushion Flower)

Handsome border plants. succeeding in any ordinary soil if well drained and in a sunny location, and should be grown in every garden where cut flowers are wanted: ther last a long time when picked and placed in water.

CAUCAFICA (Blve Bonnet)-A seft and charming shade of lavender: commences to bloom in Jume, throwing stems 18 to 24 inches high until September.

\section{SEDU⿴囗十⺝木 (Stonecrop)}

The dwarf varieties are charming plants for unny positions in the rockery, etc, and the taller kinds make effective color groups in the border. They thrive in almost fny soil. They are especially fond of sand and full sum, and may be considered the backbone of the Amer:can rock garden.

FRECT-GROWING-Useful and pretty plants for the border, producing their interesting flow ers during late summer and fall.

IEBOLDI-Round, succulent, glaucous foliage; bright pink flowers in August and September. SPECTABILE “BRILIIANT' -A rich color ed form of the preceding, being a bright amaranth-red.
SPURIUM COCCINEUM-A beautiful rosy crimson-flowered form; July and August. 6 ins. SPIREA (Goat's Beard; Meadow Sweet)

Elegant border plants with feathery plumes of flowers and neat, attractive foliage; succeeds in all locations.

ARUNCUS-4 feet. June. Produces long, feathery panicles of white flowers, forming graceful plumes.

FILIPENDUIA (Dropwort)-Numerous corrmbs of white flowers on stems 15 inches high. June and July; pretty fern-like foliage.

STATICE (Great Sea Lavender) IATIFOIA-A valuable plant either for the border or rockery, with tufts of leathery leaves and immense candelabra-like heads, frequently $1 / 2$ feet high and 2 feet across, of purplish blue, minute flowers during July and August. These, if cut and dried, last in perfect condition for months.

\section{STOKESIA}

(Cornflower Aster; Stoke's Aster)

A most charming and beautiful native hardy plant which grows from 18 to 24 inches high, bearing freely from early July until late in October, its handsome lavender-blue centaurealike blossoms, which measure from 4 to 5 inches across. It is of the easiest culture, succeeding in any open, sunny position; desirable as a single plant in the hardy border and effective in masses or beds of any size.

CYANEA COERUIFA-Beautiful light blue.

THALICTRUM (Meadow Rue)

ADIANTIFOIIUM-A beautiful variety, with foliage like the Maidenhair Fern and miniature white flowers in June.

AQUIIFGIFOIIUIM-Gracefu? foliage like that of Columbine annd rosy purple flowers from May to July, 2 to 3 feet.

THERMOPSIS (False Lupine; Buffalo) CAROIINIANA-A showy, tall-growing plant, attaining a height of 3 to 4 feet, producing long spikes of yellow flowers in June and July.

THYMUS (Thyme)

The eharming Mountain Thymes make a perfect clcse, frąrint carpet on hot, dry, sunny banks where grass is difficult to establish; they are a sheet of blossom in June and July. Excellent for carpeting patches of spring-flowering bulbs.

COCCINIUM-Plants become completely cover ed with brilliant crimson-scarlet flowers.

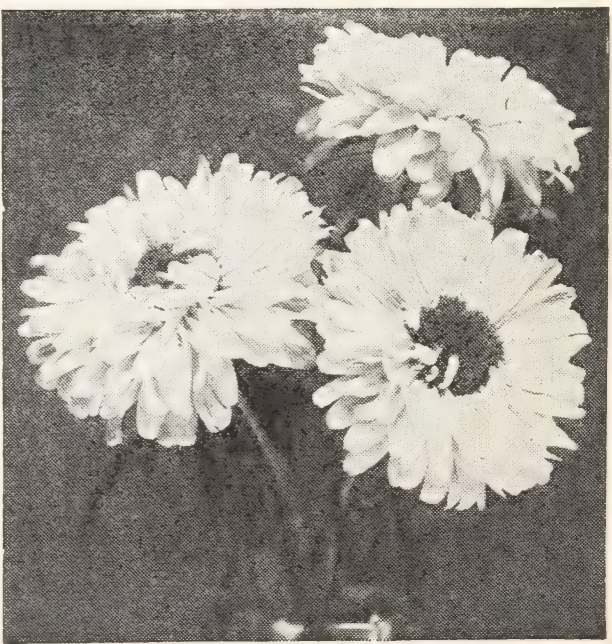

Chrysanthemums (Hardy) 
TRITOMA( Red Hot Poker; Flame Flower; Torch Lily)

PFITZER (The

$\mathrm{E} \mathrm{v}$ e $\mathrm{r} \mathrm{b} l 00 \mathrm{~min}$

Fla $\mathrm{me}$ Flower)

The free and con-

tinuous blooming

qualities of this

variety has made it one of the great bedding plants, and when we consider that there are few flowering plants which are suitable for massing under our severe climatic conditions it is little wonder that such an elegant subject should become so popular. Succeeds in any ordinary garden soil, but responds quickly to liberal treatment. Hardy if given protection, but the most sat isfactory method of wintering is to bury the roots in sand in a cool cellar. In bloom from August to October, with spikes 3 to 4 feet high, and heads of bloom of a rich orange-scarlet producing a grand effect either planted singly in the border or in masses.

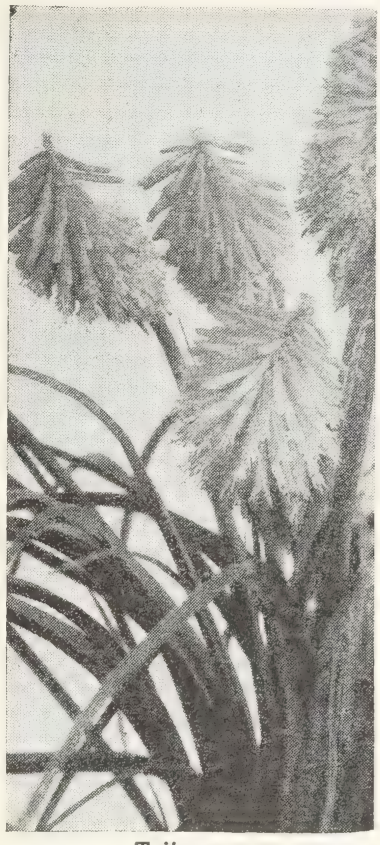

Tritoma

QUARTINIANA-A strong growing, thickstalked variety blooming late in May with flower cones 10 to 12 inches long. Orange-red at first. but yellow on bottom half as bloom matures. Perfectly hardy here; does not need protection.

TROLLIUS (Globe Flower)

EUROPAEUS, ORANGE GLOBE-Desirable

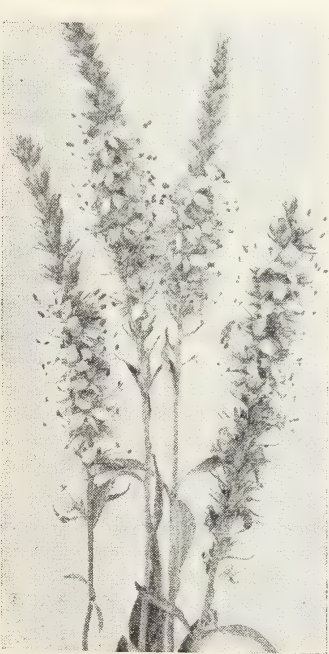

Veronica

free-flowering prain producing their giant bright yellow, but tercup-like blossoms on stems 1 to 2 feet high from May until August; succeeds ad mirably in the bord. er in a half-shady position.

\section{VALERIANA}

(Valerian; Gar den Heliotrope)

C O C C I M Showy heads of old rose flowers. June to October. 2 feet.

\section{VERONICA}

\section{(Speedwell)}

A family contain ing some of the most beautiful subjects for the hardy garden and rockery. Giv en a rich, well drain ed soil in an open situation in full sun they will all thrive in an amazing manner.

AMETHYSTINA-8 to 12 inches. June. A slender species, with short spikes of amethyst. blue flowers.
INCANA (Candida) - 1 foot. July and August. A white, wooly plant; flowers numerous; blue. Has good appearance, both in and out of bloom. Tiseful in rockery or border.

IONGIFOLIA SUBSESSILIS-2 feet. July to September One of the handsomest blue-flowering plants. Perfectly hardy and increases in strength and beauty each year. Spikes completely studded with beautiful blue fiowers; fine for cutting and one of the best plants for the hardy border.

RUPESTRIS-A fine rock plant growing 3 to 4 inches high; thickly matted, deep green foliage, hidden in spring under a cloud of bright blue flowers.

RUPESTRIS ROSEA-Similar to the above in habit of growth. The flowers form a carpet of bright rose; good foliage.

SPICATA-18 inches, June and July, Long spikes of violet-blue flowers.

VIOLAS (Tufted Pansies)

The improved forms of Viola Cornuta are rapidly growing in favor. The flower continuously for nearly eight months in the year; and while their flowers are not so large as those of the Pansy, their bright colors and floliferousness make them welcome additions to any garden.

\section{CORNUTA IUTEA SPIFNDENS-Golden}

\section{vellow.}

FIORAIRE-A gem, having the growth of the bedding Viola and producing profusely all summer through, large blossoms of true blue. This Viola is famous in and around Geneva, Switzerland and is a product of the well known Monsieur Correvon.

JERSEY GEM (New)-Possesses the dwarf habit and continuity of blooming of the true horned Viola (V. coruta), and the vigorous, bushy growth and roundish foliage of the finest English bedding varieties. Color is pure, rich violet, and slightly perfumed. It is one of the best introductions in the list of the hardy plants in recent years.

VIOIA PAPIIIO (The Butterfly Violet)-A distinct and attractive variety of the tufted Pansy producing its violet-blue flowers with dark eye from early spring until late in the fall.

YUCCA (Adam's Needle)

FIIAMENTOSA-Among hardy plants there is nothing more effective and striking for isolated positions on the lawn or on dry banks where few o $t \mathrm{~h}$ e $\mathrm{r}$ plants thrive. It is also indispensable for the rockery. Its broad, swordlike evergreen foliage a $n$ d immense branching spikes of d roop ing, creamy white flowers, rising to a height of 6 feet, render it a bold and hand$s \quad 0 \mathrm{me}$ subject wherever placed. Should be planted in spring.

\section{VARISGATED} IEAF-A beau tiful and striking plant, resembling the Filamentosa in every way, ex cept that the deep green bay onet shaped leav es are striped on the outer edge with a light yel. low stripe. Very o r n a m e n tal. Blooms the third year.

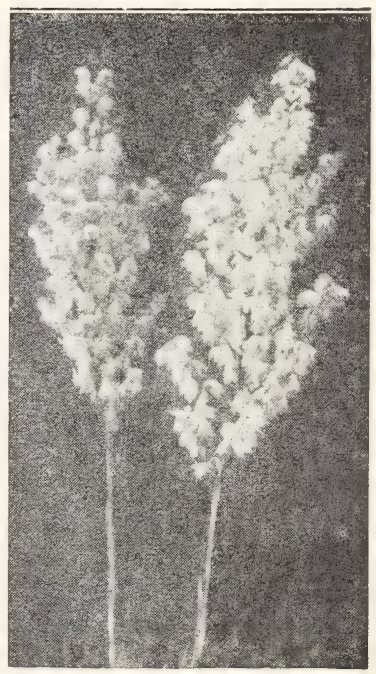

Yucea Bloom 


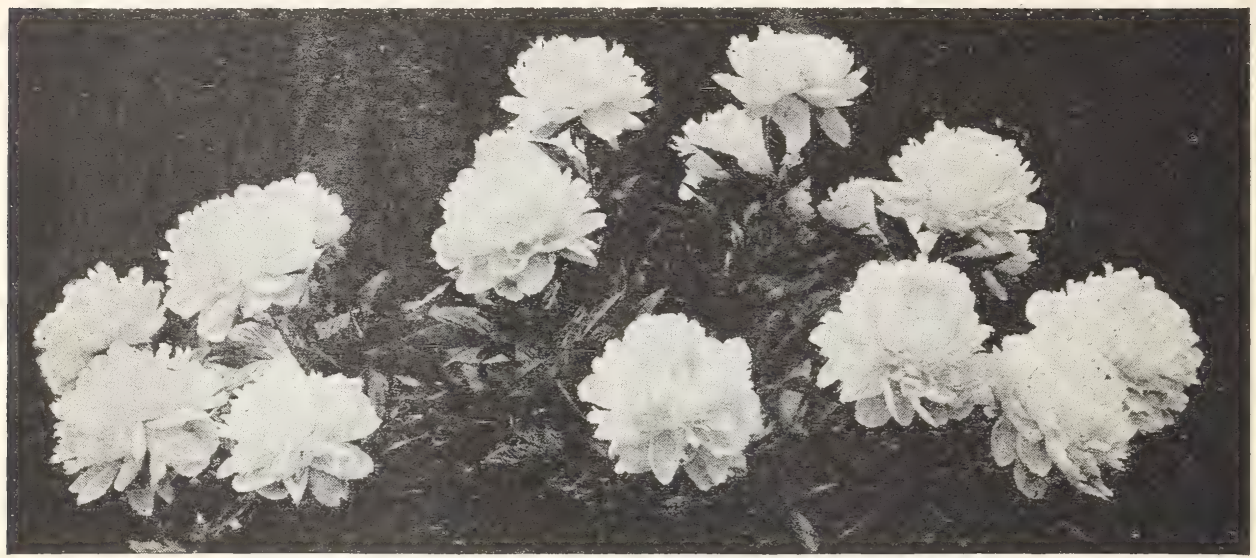

Sarah Bernhardt

\section{THE GORGEOUS PEONIES}

The improvement in the beauty of the Peony and their ever growing popularity is one of the phenomenies of the horticultural world. They have became the premiers of the spring flowers and their gorgeous bloom is being appreciated by millions of people. Standing the winters without attention and when once established lasting many years make them practical as well as beautiful, and their usefulness does not end with the blooming, the sturdy and pleasing foliage lasting throughout the summer and fall. There are many hundreds of varieties varying so little from one another, in many cases, as to require an expert to distinguish them, but we have made careful selection of the best, and you will not be disappointed in any variety that you choose from this list.

\begin{abstract}
ANGFIUS-Double, outer petals blush when they first open. Pale yellow center. Center fluted. A seedling produced by us, offered for the first time.

AUGUSTIN D'HOUR-Deep rich solferino red with slight silvery reflex. Midseason. Strong grower and prolific bloomer. One of the most satisfactory.

CAMIIII CAIIOTT-Beautiful rose pink. Midseason.

CHINENSIS AIBA-One of the old standard full double pure white. Mid-season.

CHINESE CHINENSIS RUBRA-Double purplish red, sweet scented. Late.

COIIIEN-Creamy white with outer petals light pink. A few pink petals in the center. Beauti-
\end{abstract} ful pompom center, not finely slashed.

COURONNE D'OR- "Crown of Gold". Pure white with a circle of gold stamens. Fragrant. DUCFESS DE NEMOURS-Sulphur white with greenish reflex. Especially pretty when half open. Mid-season.

DUKE OF WEILINGTON-Ivory white with creamy center. Large and full. Fine. Late. EDULIS SUPERBA-Deep rose pink. Fragrant. Early.

EIIZABבTH-One of the most beautiful peonies we have ever grown with its combination of colors blended together. Outer petals blush pink, center cream, and center petals edged with crimson. Late midseason.

EXCEISIOR-Semi-double pale pink. Center petals dashed with red.

FANTASY-Pale pink with a mass of yellow stamens in center, and also stamens and finely slashed petals between the lower and upper half of the flower. Center petals edged with crimson. Another of our valuable seedlings.

FEIX CROUSE-The leading dark red variety. Rich, brilliant ruby red. Fragrant. One of the
FESTIVA MAXIMA-Considered by many the best white ever grown. Very large and full, pure white with center petals edged with crimson. Very strong grower and heavy bloomer. Early mid season.

FLORAI TREASURE-Clear delicate pink. Very double. Fragrant. Fine. Midseason.

HFRCUIES-Semi-double delicate pink, with yellow stamens showing throughout among the petals; large and full. An extra fine variety. Midseason.

HUMrI-One of the finest of the old standbys. Deep pink, very large and full and cinnamon scented. The best late deep pink.

INVINCIBIE - Semi-double, with elongated buds, similar to Samson, but a deep pink.

KARI ROSENFIEID-Claimed to outshine all red peonies in magnificence of coloring, perfect formation of flower, abundance of bloom and strength of roots. Received first prize of the American Peony Society in 1911. Flower large, semi rose type, a perfect ball-like form when fully open of a perfect deep rich crimson on long stems. Has proven ideal both for landscape planting and for cut flowers. Midseason.

I'ECLATANTE-Large full flowers, deep purplish crimson. Late midseason.

IOUIS VON FOUTTE-Semi double, deep vio. laceous red.

MARS-Large bomb type. Outer petals blush pink, pompom center made up of a mass of pale yellow shredded petals. A strong vigorous grower. One of our seedlings never offered before.

MARIE JAQUIN-Semi double. Rosy white with a mass of golden stamens in the center. This variety suggests our native water lily. A favor. ite with all who see it.

MONS JUIES EIIE-Bomb type. Large globs ular bloon, glossy lilac pink shading to deeper rose at the base. Somethimes called the king of all peonies. Midseason. 
MONS. MARTIN CAHUZAC-Semi rose type. Claimed by some to be the darkest peony in exis. tence. Large, full well formed flowers forming a perfect ball of deep maroon with garnet hues and a brilliant black luster. An extraordinary variety. Late midseason.

MONS. THFIRS-Large deep pink on very tall stems. Beautiful. Midseason.

PAUI NEYRON-Large. Deep pink, the same color of the Paul Neyron rose.

PIFRRE DESSזRT-Large, fringed full flow er of amaranthine red shaded with garnet, with a velvety tint. Early.

POMPEI-Large bomb type, similar to Mars, but outer petals are a deeper pink and the pompom center is a decided yellow. This is another of our valuable new seedlings.

RUBRA TRIUMPHANS-Deep purplish pink Semi double. Midseason.

SAMSON-Semi double with elongated buds. Light pink with center petals slashed. Some flowers have extra petals in the center making them double. A tall strong grower and a very fine variety. One of our seedlings.

SARAH BFRNFART-Semi rose type. The strongest growing of all peonies. Flowers of remarkable size. Full and double blooming in clusters. Apple blossom pink with each petal silver tipped, giving it the appearance of a border of pure white. Very fragrant. Distinct from all other peonies. Should be in all collections.

SOIFATERRE-Crown type. Outer petals white, center sulphur yellow fading to white. Fine form on long sturdy stems.

TRICOIOR GRANDIFIORA-Soft rose with salmon center.

TRIUMPH DU NORD-Deep violet rose. VFNUS-Very unique and conspicuous. Delicate shell pink on very long high stems. Rose fragrance. Midseason. Much sought for.

WINSOMF-Semi double LaFrance pink. A seedling of great value.

\section{OFICINAIIS TYPE}

All very early, the first to bloom.

OFFICINAIIS ROSEA SUPERBA-Beautiful large soft shell pink.

OFFICINAIIS ROSEA PIENA-A bright cherry red fading to pink. Perfect form.

OFFICINAIIS RUBRA PIENA-The oldfashioned dark red double peony.

OFFICINAIIS TENUIFOIA FLORE PIENA - The very rare old deep dazzling crimson peony with fringe leaf foliage. Nothing can be more beautiful than one of these plants when in bloom. With each fiery red blossom set in the top of the beautiful green fringed foliage, like a ruby in a dark setting. The very first to bloom. It is gone before the old fashioned early red begins.

\section{JAPANESE AND SINGLE PEONIES}

For over forty years we have been growing single peonies and where we have sold them they have always brought us orders for more. But it was only in the few years that their value and

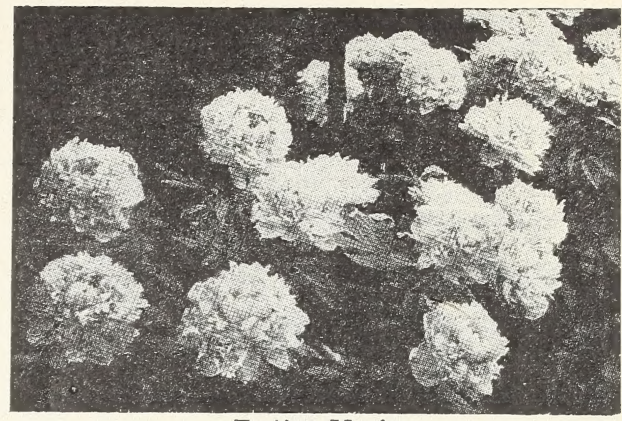

Festiva Maxima

beauty seems to have become generally known and they have now come into their own much deserved popularity.

For many years we have been growing and selling one variety which we called simply, Sin. gle Blush, for lack of a better name. We have now given it the name of Regent. It is a delicate flesh tint in the bud and when it first opens later fading to white. The center is composed of a mass of beautiful golden yellow stamens, giv. ing it the appearance of a beautiful pond lily. It is the most prolific variety to bloom that we have ever grown, either double or single and can be planted most any time and will bloom right along. We have planted it in late Spring but it came right out with a full crop of blossoms. Blooms in clusters, not all opening at the same time. We cannot recommend this variety too highly. It is very sweet scented.

We have received hundreds of letters in past years telling us of the wonderful results that this peony had given. We have developed a number of deeper shades from seedlings of this variety and are now able to offer several colors as folows.

BUTTrRFTY-Single, deep cerise petals shaded to light pink on outer edge. Has a fluttery butterfly effect closing up at night.

INNOCENCE-Single, pure white, with an elongated bud. Looks like a large white poppy. Has a large yellow center. Exquisite.

vasUvIUS-Single deep pink, shaded lighter at tip.

WATERIIIY-Single pale pink, large cluster of prominent, clear yellow stamens in center, re sembling a rosy water lily.

VUICAN-Single deep pink, almost red, fading to pink.

IMIKADO-The best known and leading Japanese Peony. First exhibited in this country at the World's Fair, Chicago, by the Japanese Government. Outer petals uniform crimson and center a broad partially transformed cluster of - staminoids, chamois yellow faced with crimson. A typical oriental color. Fine cut flower and lasts well. The dark green foliage makes it a splendid landscape plant.

\section{BEAUTIFUL ROSES}

The rose has always, probably, been the most generally popular flower in America. But with the introduction of the many new and valuable varieties of the last few years, especially in the Hybrid Tea class, which makes it possible for most anyone with a few feet of ground to have an abundance of fine, fresh fragrant roses all summer long, their popularity seems to have doubled.

We can now offer you the best of the old varieties as well as the best of the new. Our stock consists of considerably better than a hundred varieties from which it is possible to select any color or shade known in roses. All roses should have open, sunny location. Clay loam is the ideal soil but they will do well in most any good fertile, well drained soil. We have a book of directions for the planting and care of roses which will be furnished free to purchasers of roses on application. 


\section{CLIMBERS}

AVIATEUR BIFRIOT-Beautiful little buds of saffron vellow shaded apricot. Lighter on opening. Quite fragrant. Glossy foliage.

BAITIMORE BrIIF-The old standby. Large white flowers blooming in clusters.

BIUE RAMBIFR-Not a true blue but the nearest approach to a blue ever found in a rose. A violaceous red.

CIIMBING AMERICAN BEAUTY-The mod.

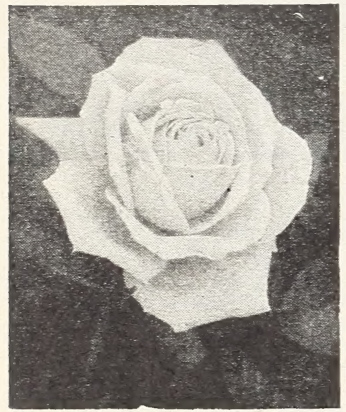

erately fragrant, rich rosy crimson 3 to 4
inch flowers are produced in gre a t abundance. It will succeed in almost makes a very vigor. ous growth.

CRIMSON RAMBIIR-Great mass. es of crimson semiborne by these vigorous plants. Desirable pillar and porch plants.

DOROTHY PERKINS-One of the most notable climbClimbing American Beauty ing roses. Clear fragrant; borne in great profusion and lasts a long time. The plant makes a very strong growth; ; foliage is glossy, bright green, and per. sists until cold weather.

DR. VAN FIFIT-Probably the best climbing rose in cultivation. Perfectly formed, long pointed, deep pink buds on long stems, with several in a cluster, that opens to a lighter shade of pink. It is a vigorous grower with glossy, dark green foliage. It is a delight to the eye all sum. mer.

EXCEISA (Red Dorothy Perkins)-A radiant blood-red cluster rose, as free and double as Dorothy Perkins of which it is the red proto. type. The clusters are very large and fairly cover the vines.

FAIRFIEID-Similar to the Crimson Rambler in color and size of flowers, but its foliage is darker and keeps in better condition, while the flowers are borne all summer. It is generally considered an everblooming Crimson Rambler.

GARDENIA-Buds bright yellow, flower cream. FIAWATHA-Large clusters, single, intense crimson petals shading to white at the base.

MARY WATIACE (New)-Although a good pillar rose, it becomes self-supporting and makes an ideal door-yard bush. The flowers are semidouble, bright clear rose-pink with salmon base. These are often four inches wide, and appear intermittently during the season, following their first glorious outburst in late spring.

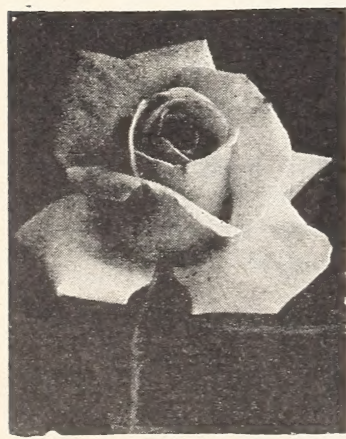

PAUI'S S C A RIET CIIMBERThe brightest and purest red of all the Pillar Roses. Flowers are borne in clusters that retain their color until they fall, the color being intensified by the numerous $\mathrm{ye} 110 \mathrm{w}$ stamens. A vigorous grower and a good QUEFN OF THE PRAIRIES - An ol d-time favorite. Bright pink flowers that are sometimes white striped, c $0 \mathrm{~m} \mathrm{p}$ a ct clusters. Plant is hardy in
SEVIN SISTrRS-An old time variety of good sized pink roses blooming in clusters.

SIIVER MOON-To the rose lover who has not enjoyed Silver Moon, a delightful experience is in store in contemplating this extraordinary vigorous climber, decorative all through the growing season by reason of its great canes and deep, rich foliage, but literally a wonder at bloom-time for its long, well-shaped buds of faint yellow which open into immense pure white flowers, often reaching 4 inches or more in diameter. These blooms are semidouble and with very distinctly curled and curved center petals which surround the bright yellow stamens and add piquancy to the whole effect. An indispensable white rose.

TAUSENDSCFON-Or Thousand Beauties, i the appropiate name of this lovely, vigorous and desirable Hardy Climbing Rose; almost thornless. The buds are cherry pink, opening to softer shades, all shades being found in a single cluster; has glossy, light green foliage. A highly desirable and distinctive rose for covering walls, fences, porches and pergolas, and unique among climbers.

WHITE DOROTHY-A magnificent, clustered Rose. with good strong virility and climbing habit, the vines are a sheet of white during their blooming period.

YFILOW RAMBIER-Has been called a yellow climber but this is a misnomer. Buds are light yellow but flowers are nearly white.

\section{HYBRID PERPETUALS}

AMPRICAN BEAUTY-Large, globular, crim. ANNA DE DIFSBACH-Pink. Long pointed buds.

BARON DE BONSTETTIN-Deep velvety crimson.

CIrO-Flesh color, very large. Fine. FTRIN - D e e p crimson.

E U G $\mathbf{E} \quad \mathbf{N} \mathbf{I}$ FEURST - Dark crimson with purple shadings.

FISHFR HOIMES -Bright crimson.

FRAU I A R D DRUSCHII - The best white. Large and silvery and splendid bloomer.

G $\mathbf{I}$ N. JACK

Bright crimson. Free bloomer.

G F O. ARENDS (Pink Druschki) -

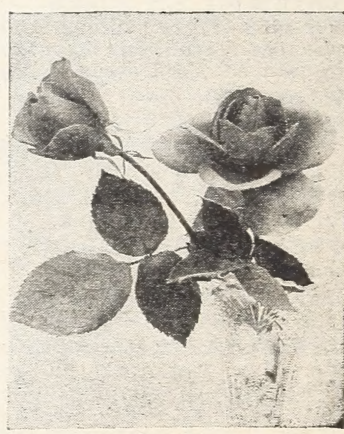

Anna De Diesbach
The best pink of the class. Free bloomer. Fine shaped buds, opening into large flowers.

GEO. DICKSON-Velvety black.

J. B. CIARK-Crimson. Fine fall bloomer. MME. GABRIFI IUIZETTE-Silvery pink blooms of fine substance and attractive form. MAGNA CHARTA-Large, pink, strong grower. MARGARET DICKSON-Flesh changing to white.

MARSHAII P. WIIDFR-Late crimson.

MRS. JOHN IAING-Soft pink. Fragrant. Free bloomer with immense blooms.

PAUI NIYRON-Deep pink. The largest rose and the best bloomer of the class. Blooms all

PERSIAN YELIOW-Yellow producing a profusion of fragrant blooms in spring.

PRINCE CAMIILE DE ROHAN-Deep velvety maroon.

SOIIFI D'OR-Reddish gold, shaded with orange. Buds are exceptionally lovely and the flowers large and full.

ULRICH BRUNER-Cherry red. Free blooming. Large blooms on long stems, carried by a plant of vigorous growth. 


\section{HYBRID TEAS}

AIFXANDER HIII GRAY-Pale lemon yellow.

BETTY - Coppery rose overspread with yellow. CHAS. K. DOUGIAS-Flaming scarlet.

COIUMBIA-Glowing pink.

DUCHESS OF WEIIINGTON-Intense saffron yellow, stained with crimson.

EDWARD MAWIEY-Deep velvety crimson. FTOIIE DE FRANCE-Vivid crimson.

FRANCIS SCOTT KEY-Deep red, large, very double.

GFNPRAI MCARTHUR-Bright scarlet.

GOIDEN FMBIEM-Rich deep golden yellow GOIDEN OPHEIIA-Similar to Ophelia with a golden yellow suffusion.

GRUSS AU TEPITTZ-Scarlet, always a mass of bloom.

HADIEY - Velvety crimson.

HEIFN GOUID-Red.

FrRMOSA-Pink.

HOOSIFR BEAUTY-Glowing scarlet.

J. I. MOCK-Outside of petals deep pink, inside silvery rose.

JUIIFT-Old gold and red.

TAISFRIN AUGUSTA VICTORIA-Creamy white.

KIIIARNEY-Pink

RIIIARNEY BRIIIIANT-Deep rosy carmine.

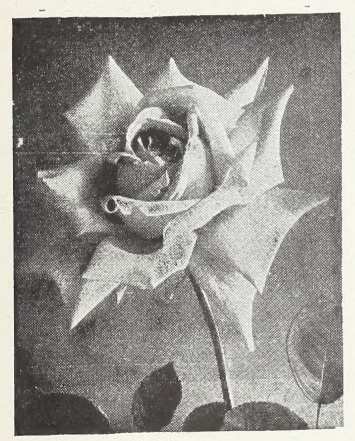

K I I I A R N IY WHITE-Large sil-

IADY HILIINGTON-Deep apricot yellow.

IADY URSUIA Flesh pink.

IA TRANCE -

Rose pink. Deep buds.

IOS ANGEIES Flame pink, toned with coral, shaded with gold at base of petals. Extra fine. MAMAN COCHFT - Rich coral pink.

MIS S IOITA ARMOUR - Coral, golden and coppery Columbia

\section{MiscellaneOUS ROSES}

F. J. GROOTFNDORST ("The Baby Ramblex Rugosa Rose.') - Typical rugosa foliage, health and habit, of compactly bushing, moderate growth; but revealing its baby rambler cross derivation in the form, color and season of its bloom. Not only suitable for association with medium shrubs, like other rugosas, but on account of its remarkable bloom and superior bush character. deserves more prominent exhibition, either as a single specimen or in a separate massed group. The bloom is in clusters of oversized, Baby Ram. bler, which like this type, produces from fairly double red flowers resembling the Crimson Rambler are produced from early summer till fall HUGONIS (Novelty) - A remarkable and very valuable briar rose brought in from China. Grows and spreads quickly to as much as 6 feet at $\mathrm{m}$ a turit y. Blooms extrava.

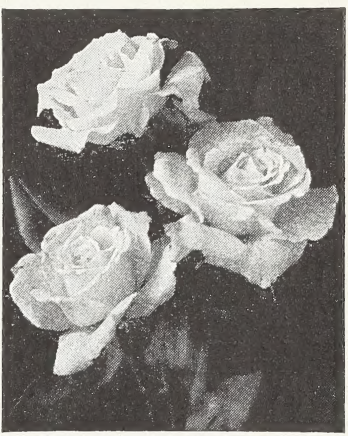

Kaiserin A. Victoria gantly in May full length of last year's shoots. Flowers single, ranging from deep gold to can ary, with conspicuous stamen tufts.

\section{BABY RAMBLERS}

Dwarf bushes, blooming continually. Flowers in clusters of small roses.

BABY RAMBIFR-Crimson.

BABY TAUSENDSCHON-Pink.

KATHERIN ZEIMET-White

CECIIE BRUNNER-Pink.

EIIEN POULSEN-Bright rose pink.

ERNA TESCHENDORTF-Carmine red.

IDEAI-A wonderful quality of bloom. A rich deep garnet red. The very best of the Baby Ramblers that we have ever grown.

MISS EDITH CAVEII-Brilliant crimson with white eye.

\section{MOSS AND RUgOSA ROSES}

MME. ABEL CHATENAY-Carmine rose shad ed with salmon.

MME. BUTTERFIY-Bright pink, aprieot and gold.

MMT. CAROLINE TESTOUT-Rich pink. MME. EDOUARD HERRIOT-Coral red, shad. ed yellow and scarlet. An odd and fascinating shade.

MRS. AARON WARD-Yellow.

MRS. A. R. WADDEII-Scarlet buds opening to a deep reddish saffron.

MRS. CAIVIN COOIIDGE-Golden yellow.

OPFrIIA-Salmon flesh, shaded rose.

PHARISAFR - Rosy white, shaded salmon.

PREMIER-Clear, pure rose pink.

RADIANCE-Carmine pink.

RED RADIANCF-Dazzling crimson.

ROSP MARIE-Clear rose pink.

SOUVFNIR DE CIAUDIUS PFRNET-SUn flower yellow. One of the finest and most lasting yellow varieties.

SOUVFNIR DF GFORGES BFCKWITHLarge salmon pink and yellow.

SOUVENIR DE GEORGES PERNFT-Briek red buds, opening to terra cotta pink.

SUNBURST-Rich yellow shaded coppery

VISCOUNTESS FOIKSTONE-Creamy pink. WIM. F. DREFR-Shell pink, yellow at base. WIIIIAM R. SMITH-Creamy white suffused with rose pink. Strong grower.

WILIOWMERE-Shrimp pink.

We can furnish Moss Roses in a variety of colors, as Red, White, Pink, Crested, etc. And Rugosa in the type, and in some of the hybrids.

\section{BULBS FOR SPRING PLANTING}

CANNAS-Best Franch.

CAIADIUMS (Elephant Ear).

DAFIIAS-In a variety of colors.

GIADIO I U S

These are among the most showy and brilliant of all bul bous plants. All col ors and combinations.

\section{BULBS FOR} FALL

\section{PLANTING}

We carry a com plete stock of fall bulbs such as $\mathrm{Hy}$ acinths, Tulips, Cro cus, Narcissus, ete. imported from $\mathrm{Hol}$ land each fall. These must be planted in the fall to succeed. Prices on application in fall.

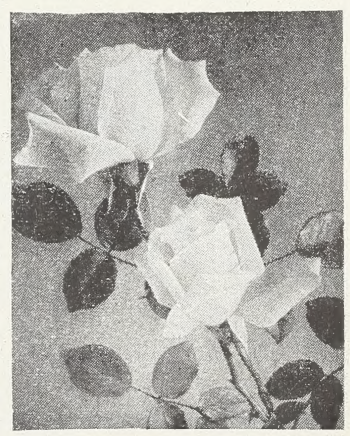

Mrs. Aaron Ward 


\section{RARE VARIETIES and NOVELTIES}

Here are some very rare varieties, some of which can be obtained only of The Fremont Nursery and none of which can be found readily anywhere.

\section{MOERHEIMS BLUE SPRUCE-}

The most blue variety known. An improvement on Kosters. More intense blue, longer needles, covering the old growth more completely. A more compact tree. You must see these to appreciate their superiority. We can now furnish them in trees from $3 \frac{1}{2}$ to $4 \frac{1}{2}$ ft. high. Call and see them.

JAPANESE MAPLE, Variety AshioBeni-The best red of all the Japanese Maples, even including the Blood Leaf (Atropurpurea). Holds its red color till the frosts kill the leaves. Stands the hot summer sun better. We can also furnish seeding Japan Maple, the kind that is usually on the market at present, at a much lower price.

VIBURNUM CARLESI-A P i n k Snowball, with delicate, waxy, sweet scented blooms. Outside of each floret pink, inside white on opening. Intensely fragrant. A few blooms will scent an entire room. Very beautiful and rare. Bush completely covered with blossoms in early spring.

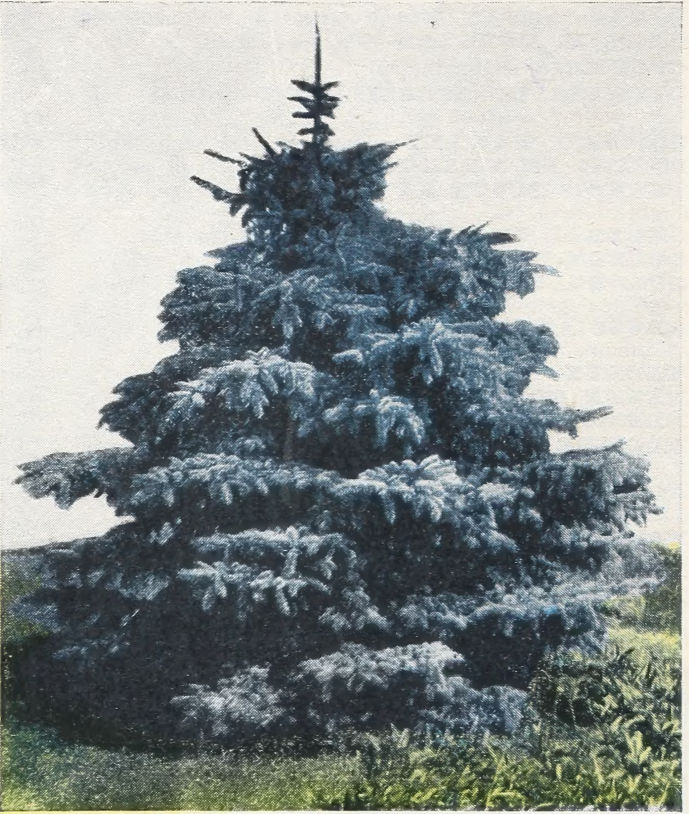
A pretty shrub when not in bloom. We have a limited number of these in large, strong bushes, 3 to $4 \mathrm{ft}$. high and about as broad across the top.

MAGNOLIA-We have a nice lot of small plants of the flowering Magnolias which we hope to be able to offer next year.

SCHWEDLERS MAPLE-Very scarce. See description under Maples. We have some beautiful strong, straight, wellrooted trees 6 to $8 \mathrm{ft}$. and 8 to $10 \mathrm{ft}$.

FRINGE LEAF and SINGLE PEONIES -A good stock of both. See Peony list.

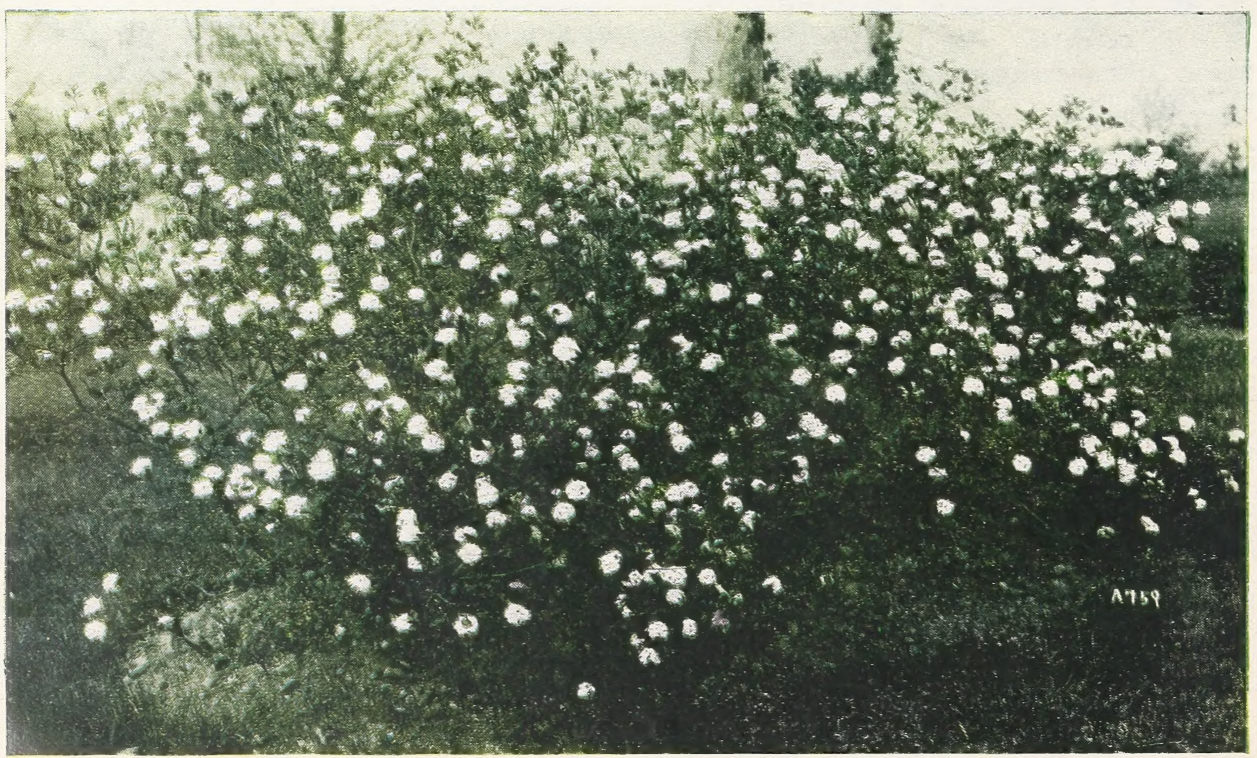

